\title{
Anmeldelser
}

Dansk præste- og sognehistorie. Bind 10 Haderslev stift. Hefte 3-10. Udgivet af A. Pontoppidan Thyssen, Århus 1985, 711 sider

I Sønderjyske Årbøger 1978 introducerede jeg de to første hefter af Dansk præst- og sognehistorie bind 10, som omfatter Haderslev stift. Derfor skal her indledningsvis kun kort opfriskes, at ophavsmanden til denne enestående landsdækkende lokalhistorie var den mangeårige sognepræst ved Sct. Matthæuskirken i København, Paul Nedergaard - kendt desuden for bl.a. 12 udgaver af Kirkelig Håndbog. Paul Nedergaard var utratteligt optaget af at indsamle biografiske og statistiske oplysninger om alle sogne i Danmark med det formål at skabe en hidtil ukendt lokalkirkelig og åndskulturel geografi. Arbejdet ville resultere $\mathrm{i}$ et mammutværk på 10 store bind á ca. 10 hefter med ca. 80-100 dobbeltspaltede sider. Det første hefte så dagens lys i 1949, og Paul Nedergaard nåede inden sin død i 1970 at se næsten alle de kongerigske sogne registrerede. Tilbage stod kun halvdelen af Ribe stift og Haderslev stift. Ribe stift løb op i 16 hefter + et registerbind. Det resterende arbejde blev lagt $\mathrm{i}$ hænderne på et patronat med nu også afdøde provst J. Juul Sørensen, Hellerup, som redaktør. Efter en længere pause lykkedes det at overtale dr. teol., nu professor i kirkehistorie, Anders Pontoppidan Thyssen, Århus, til at påtage sig opgaven med at sørge for værkets fuldendelse, så Haderslev stift ikke kom til at mangle. Det var et absolut heldigt valg, da den nye udgiver just var ved at færdiggøre sin store undersøgelse i 7 bind af "Vækkelsernes frembrud i Danmark «. Sidste bind bar netop titlen »Vækkelse, kirkefornyelse og nationalitetskamp i Sønderjylland 1815-1850«. I redaktionen indtrådte cand.jur. og oecon. John W. Oldam, lektor Henry Petersen og sognepræst Urban Schrøder. De to første har været hovedleverandører, men har haft gode hjælpere i Urban Schrøder, Günter Weitling, Inga Blaabjerg, Anders Malling, Jens Holdt, H. V. Gregersen, Asger Nyholm og Helge Rønnow m.fl., samt de få præster, der har haft mod og evner til selv at portrættere deres eget sogn. Således er nu med det sidst udkomne hefte behandlingen af Sønderjylland ført til ende. Tilbage står blot de tre nordligste provstier, Fredericia, Vejle og Hedensted, som forventes udsendt i 1986. 
At forsøge en nærmere omtale af de enkelte sogne må anses for hovedløs gerning $\mathrm{i}$ en forholdsvis kort anmeldelse, hvorfor opgaven må indskrænkes til at gøre opmærksom på hovedlinjer og uforpligtende vurderinger - da jeg ikke er faghistoriker - $\mathrm{i}$ håb om at kunne blive en slags appetitvækker for kommende læsere.

Dispositionen går ud på, at hvert provsti indledes med en oversigt over provstiets omfang og historie. Herpå følger for de enkelte sognes vedkommende: topografi, størrelse, landskabsformer, bebyggelse og oldtidsminder m.m., samt stemmetallene ved de tyske rigsdagsvalg, folkeafstemningen 1920 og efterfølgende folketingsvalg. Dernæst følger en oversigt over den ældre præsterække frem til 1850, undertiden krydret med dramatiske hændelser og morsomheder for en nutidig læser. Hovedvægten er lagt på tiden efter 1850 , hvor den egentlige kulturkamp foregår og med 1920 som en selvfølgelig og afgørende mærkepæl for landsdelens skæbne i nyere tid. Men også skolers og kirkebygningers historie inddrages naturligvis. Det samme gælder højskoler, frimenigheder, foreninger, søndags- og missionsblade m.m., ligesom der tegnes portrætter af betydelige degne, missionærer og lægfolk m.fl. Også menighedsråd, altergæsters antal og folketal er med, hvorpå der sluttes af med den nye præsterække og litteraturhenvisninger.

Men såvel kirkeligt som folkeligt er det naturligvis brydninger og udslag af de teologiske og nationale spændinger, der efterlader de varigste indtryk. Det er absolut ingen let sag at vurdere, i hvor høj grad de religiøse forhold har gjort sig gældende for den nationale rejsning omkring og især efter 1848-50. Men det synes dog at stå klart, at mange af de tyske præster både før og efter krigene slet ikke har været så ringe endda, som de traditionelt plejer at blive fremstillet. Det hører, så vidt jeg kan bedømme, til én af bogens fortjenester, at den dokumenterer, at disse præster langt fra kan dømmes over én kam, men at de bedste af dem virkelig var mere interesseret $\mathrm{i}$ kirkelig fornyelse og enhed end en nationalpolitisk spaltning af deres menigheder. Også den herrnhutiske indflydelse var engang stor. Og det fortjener påskønnelse, at man her, så vidt jeg er orienteret, møder den første samlede beskrivelse af Brødremenighedens historie. Også flere delvis statistiske behandlinger af kirkelivet $i$ den tyske tid fortjener at nævnes, f.eks. i det 8. hefte om de særprægede forhold på Als og delvis også Sundeved, og som mig bekendt ikke findes tilsvarende i andre publikationer. Den forholdsvis store kirkelige tilslutning efter 1864 og nedgangen omkring 1900 springer også i øjnene. Sammen med karakteristiske forskelle 
mellem købstadssogne og landsogne og mellem nord og syd udgør de væsentlige træk af landsdelens kirkeliv.

Det siger sig selv, at arbejdet med kilderne har været særdeles betydeligt. En, i hvert fald for offentligheden, hidtil upåagtet stofmængde af stor lokalhistorisk interesse er her fremdraget fra præstegårds-, provste- og bispearkiver. Sammen med en række synodalia har det muliggjort de mange værdifulde oversigter over op- og nedgange i den kirkelige aktivitet, f.eks. de sociale tilstande og hvordan det stod til med sædeligheden (antallet af deflorerede brude!), sektvæsen og respekten for søndagshelg, gudstjenesteordninger og salmebøger, kirkedåb og hjemmedåb, men frem for alt altergangsfrekvensen, hvoraf muligvis også kan aflæses tilslutning eller protest mod periodisk bestemte kirkepolitiske strømninger, eller må tilskrives den lokale sognehyrdes teologiske observans (agendestriden) eller holdning til det altid aktuelle nationale problem. Det alment udbredte fald i kirkegængernes og altergæsternes antal i nyere tid kan vel ingen være i tvivl om hovedsagelig må tilskrives den stadig løbende sekulariseringsproces.

At det 10. bind af $»$ Dansk præste- og sognehistorie» fremover vil være en guldgrube for sønderjyske lokalhistorikere, er oplagt. Der er virkelig tale om en enestående og i flere henseender ikke før set nyskabelse på det folkelige og åndskulturelle plan, som man kun kan ønske såvel udgiver som forfattere og mange kommende læsere tillykke med. Det hører dog stadig til en af vort fædrelands betydeligste historiske begivenheder, at dansk folkelighed i Nordslesvig formåede at frembringe og fastholde en national og kirkelig åndskultur, som efter 56 års fremmedherredømme i 1920 kunne tilbagegive til moderlandet et Nordslesvig, der var mere dansk, end det havde varet før nederlaget på Dybbøl i 1864. Om det så også har bidraget hertil, at Nordslesvig i kirkelig henseende overvejende bestod af - og stadig består af selvstændige sogneenheder og ikke flersogns pastorater som i Holsten og kongeriget, ja det afhænger naturligvis af i hvor høj grad, man vil tillægge begrebet sognebevidsthed betydning for nationalt og kirkeligt sammenhold? Aspektet var nok en undersøgelse værd. Men det gælder vel her som $\mathrm{i}$ andre forhold iøvrigt, at den personlige identitet bedst opelskes og bevares under forhold, man er fortrolig med og i fællesskaber, der er til at overskue. 
Ove Jørgensen: Alfred den Store: Danmarks geografi. En undersøgelse af fire afsnit i Den gamle engelske Orosius.

North-Western European Language Evolution, vol. 1. Odense 1985.

Den stigende interesse for Danmarks tidligste nationale historie har blandt andet markeret sig ved, at vikingetiden $i$ en længere årrække hørte til de centrale forskningsområder blandt historikere, filologer og arkæologer. I perioden inden årtusindskiftet skabtes den samfundsopbygning, som var forudsætningen for rigssamlingen under Gorm og Harald. Beskæftigelsen med vikingetiden førte dog også til spørgsmålet om, hvorvidt det var muligt at belyse de forudgående århundreders forhold: De historiske kilders indhold om perioden er få og lidet oplysende, stednavneforskningens resultater omstridte i dateringshenseende og arkæologernes oplysninger upræcise, når det gælder viden om den politiske og sociale situation. Overfor dette sparsomme videnskabelige materiale står en udbredt folkelig "viden«, der skyldes sagn, gammel overlevering og tvivlsomme kilder.

Nogle af de ældste oplysninger om vore dages Danmark findes i en angelsaksisk udgave af spanieren Paulus Orosius' verdenshistorie, der i sin oprindelige form omhandlede tiden fra Adam og Eva frem til år 417. Den latinske version blev flere århundreder senere oversat, bearbejdet og ajourført ved Alfred den Stores hof (871-899) i det vestengelske Wessex. Den nyredigerede verdenshistorie indeholder blandt andet fire afsnit om Danmark, som ikke findes i det ældre værk. Det antages derfor, at de hører til 800-tallets tilføjelser. To af kilderne kendes almindeligvis som Ottars og Ulfstens rejsebeskrivelser.

Ove Jørgensens undersøgelse indeholder dels en kortfattet introduktion i Alfreds værk, teksternes overlevering og præsentation indenfor dansk historieforskning, dels et kort rids af baggrunden for den kulturhistoriske situation ved Alfreds hof. I tilknytning hertil omtales beretningens geografiske opbygning og vanskelighederne med at bestemme datidens nordretning, der er af stor betydning for forfatterens teksttolkning. Ved analyse af ældre vendinger om himmelstrøg på flere europaiske sprog, filologiske undersøgelser af andre orienteringsmeddelelser i Alfreds værk og samtidige tekster og af gamle korts udsagn afvises tidligere tydninger af den angelsaksiske beskrivelse. På denne baggrund forseger forfatteren med en kritisk gennemgang af de fire teksters indhold en nyvurdering af oplysningerne om dansk område. Diskussionen bygger især på en placering af næunte folkeslag og regioner, der især er knyttet til Syd- og Sønderjylland og Holsten. 
Mens der hverken hersker tvivl om lokaliseringen af Hedeby, »ongle« i Angel, Frisland i Vestslesvig og obotriternes land i Østholsten, er det vanskeligt at følge argumentationen for at knytte "Sillende« til grænsezonen mellem Ejderen og Trenen og begrebet »en del af danskerne« til Nordslesvig. Sprogforskeren Wolfgang Laur, som Ove Jørgensen blandt andet henviser til - som en af de få tyske forskere - tolkede i 1967 »Sillende« eller »Sinlendi«, som landskabet kaldes i de frankiske rigsannaler, til at være den østlige del af hertugdømmet Slesvig mellem Sydjylland og Flensborg Fjord eller Slien.

Historikernes og arkæologernes opmærksomhed er fremfor alt knyttet til analysen af begreberne »en del af danskernes land « og »syddanerne«, der er sat overfor sjællandske og skånske (?) »norddanere«, idet disse meddelelser sammen med beretningerne i Ottars og Ulfstens rejsebeskrivelser om Hedeby m.m. udgør vigtige belæg for Slesvigs folkelige forhold omkring år 800 . Det er dog svært at vurdere, hvorvidt det historiske billede, som forfatteren prøver på at tegne, kun genspejler situationen på Alfreds tid eller peger på ældre forhold: Mens en placering af oldsakserne i Vestholsten diskuteres, f.eks. fra arkæologisk side i forbindelse med et bestemt materiale fra ca. 200 efter Christi fødsel, fremstår slaverne i Østholsten, obotriterne, udfra en arkæologisk datering først mellem $650 \mathrm{og} 700$. Tilsvarende usikkerhed gælder forøvrigt både for frisernes og angelboernes ældre historie, hvor nye undersøgelser af jordfund synes at pege på mere indviklede forhold end tidligere antaget. Disse komplekser ligger dog uden for hensigten med Ove Jørgensens i fiere detaljer lidt fantasifulde, men i sin helhed dog tankevækkende introduktion til nogle vanskelige tekster fra det 9. århundrede.

Ole Harck

Wolfgang Prange (udgiver): Herzog Adolfs Urteilbuch 1544-70. Schleswigsches Rechtsleben um die Mitte des 16. Jahrhunderts.

Quellen und Forschungen zur Geschichte Schleswig-Holsteins. BD. 87. Neumünster 1985.

Ved midten af 1500-tallet blev Hans Iversen fra Høgelbjerg i Løjt sogn budt til bryllup. Han skulle slå på tromme for brudeparret. Bruden, der glædede sig på dagen, gav Hans et par skillinger for spillet. Det fik imidlertid brudens mor nys om. Hun blev meget vred på spillemanden og påpegede, at hun havde givet de drikkepenge, der skulle gives. 
I sin ophidselse råbte hun til en af gæsterne: „Giv denne lystige lømmel nogle på hovedet, så der farer en djævel i livet på ham!« Spillemanden fik nu først en kande i hovedet, blev derefter sparket og endelig stukket med en kniv. Knivstikket blev hans død - der naturligvis førte til en retssag.

Denne sag er sammen med en lang række andre slesvigske retsdokumenter gjort tilgængelig i en forbilledlig udgave ved Wolfgang Prange.

Det drejer sig om en udgave af "Hertug Adolfs Domsbog«, nu opbevaret i Schleswig-Holsteinische Landesarchiv under signaturen Abt. $400.1 \mathrm{nr}$. 79. Domsbogen indeholder 204 domme afsagt af hertug Adolf af Slesvig-Holsten-Gottorp og dennes råder, i tidsrummet mellem 1544 og 1570.

Hovedvægten i samlingen ligger geografisk på Husum og opland, også andre dele af Slesvig er dog repræsenteret. Den anvendte ret er overvejende Jyske Lov, men de særlige forhold i det vestlige Slesvig træder klart frem: Hatsted marsk, Stapelholm, Eidersted havde hver sin ret. Lundenberg herred var underlagt frisisk ret. Disse retslige forhold gør Prange rede for $\mathrm{i}$ et forord til domssamlingen.

Der er meget at hente for den kulturhistorisk interesserede. Det basale i landbrugssamfundet, jorden, indtager en central plads i dommene. Langt den overvejende del indeholder arvestridigheder om jord. Også handel og byer er imidlertid genstand for domsbehandling. Her er aftrykt et privilegium til skomagerne i Åbenrå. I samme by måtte en barber forsvare sig mod anklage for dårligt udført åreladning. Storbyen Husums internationale kontakter sætter sig spor $\mathrm{i}$ form af sager, der angik salg af møllesten, importerede af en købmand fra Dordrecht, samt kornhandel til Hamburg, og i en sag hvor en Husumborger beskyldtes for at tilhøre de »morderiske, ukristelige« gendøbere i Amsterdam.

Udgaven af »Hertug Adolfs Domsbog« afsluttes af et tillæg med supplerende domsmateriale fra 1500-tallet. En række sager fra Svavsted len giver indblik i retudøvelse også på mere lokalt plan.

Bogen er forsynet med gode person-, stednavne- og sagregistre. De nordslesvigske stednavne er meget bekvemt anført både i dansk og tysk form.

Der er grund til at takke Wolfgang Prange for offentliggørelsen af denne værdifulde kilde til Sønderjyllands historie. 
Claudia Annette Meier: Heinrich Ringerinck und sein Kreis. Schriften der Gesellschaft für Flensburger Stadtgeschichte E.V., Nr. 34. Flensborg 1984.

Den lutheranske kirke krævede forklaring af bibelens tekst på modersmålet og dermed fulgte kravet om prædikestole i de utallige kirker i de protestantiske områder. Rundt omkring lavedes mere eller mindre primitive prædikestole af de lokale snedkere, men langt de fleste steder ønskede man finere og smukkere udstyrede stole, udført af dygtige snedkere og billedskærere. I mange byer voksede i 15- og 1600-tallet egentlige værksteder med mester, svende og lærlinge frem. De lavede ikke blot prædikestole, men også andet kirkeinventar, stolestader, orgelfacader, nye altertavler til afløsning af middelalderens katolske inventar, ligesom de fortsatte med at lave møbler til private hjem, både adelens herregårde og borgernes købmandsgårde.

Længe har man søgt, ud fra stil-historiske overvejelser, at knytte de overleverede arbejder, kirkelige og verdslige, i grupper til enkelte kendte mestre. Først $\mathrm{i}$ de senere år har man erkendt, at de fleste arbejder er udført på større værksteder. Værkstedslederen, mesteren, entreprenøren eller hvad betegnelse man nu vælger, har aftalt leverancen med f.eks. kirkens ældste og præsten, i fællesskab har de udvalgt motiverne til prædikestol, alter eller hvad det nu har drejet sig om, og mesteren har måske så lavet en skitse heraf, og han har underskrevet kontrakten. Arbejdet er så sat $\mathrm{i}$ gang på værkstedet, fordelt på svende, lærlinge og med mesteren som den, der tog sig af de overordnede forhold samt måske også af mere indviklede eller mere kunstneriske prægede dele. En del er blevet bortgivet til andre varksteder, f.eks. skelettet til et tømrerværksted og bemalingen og stafferingen til et malerværksted. Ud fra erkendelsen af disse arbejdsforhold har mange $\mathrm{i}$ de senere år begyndt mere detaljerede studier af sådanne værksteder, deres mestre og deres virke $\mathrm{i}$ en kombination af stilistiske og arkivalske unders $\varnothing$ gelser.

En sådan moderne undersøgelse af Flensborgs største renaissanceværksted, Heinrich Ringerincks værksted, er Claudia Annette Meiers disputats. I et overordentligt grundigt arbejde har hun på godt 100 sider gennemgået ikke blot det Ringerinckske værksted, men også tilknyttede værksteder og værksteder, der groede ud herfra, f.eks. ved at svende startede for sig selv. Derefter kommer 30 sider noter, 23 sider med aftrykte kildesteder og, som et af bogens tyngdepunkter, et udførligt katalog på 114 numre over alle de genstande, der har dannet 
det egentlige grundlag for studiet. Bogen sluttes med en 21 siders litteraturliste og endelig en billed-del på 40 sider glittet papir med 107, ofte desværre alt for små og ikke altid særlig tydelige, illustrationer.

Der er således tale om en meget grundig og dybtborende undersøgelse, der bringer klarhed over mange hidtil usikre forhold, øger forståelsen for et sådant værksteds organisation og arbejdsforhold og giver kontant ny viden om Østslesvigs kirkeinventar fra renaissancen.

Mens man tidligere var tilbøjelig til at tilskrive en bestemt mester, som i dette tilfælde Heinrich Ringerinck, et større eller mindre antal værker, når blot de synes at ligne hinanden, så bliver billedet langt mere nuanceret, men derved nok også mere uoverskueligt. Allerede Richard Haupt havde kort før århundredskiftet inddelt Flensborgområdets prædikestole i tre typer: Den østflensborgske type, den vestslesvigske type og angler-typen. Nu optræder et mylder af muligheder. Der opereres med »sikre H.R.«, »tilskrevet H.R.«, »HR-værkstedet«, "H.R.-elever«, og af specificerede elever sønnen Johan og de tidligere svende Niels Tagsen og Jørgen Ringris, samt helt andre værksteder som Johan v. Bremen, H.R.'s mester, det første år han var i Flensborg, Hans Kremberg og Hans Jacobsen. I hovedsagen virker disse mange værkstedsbestemmelser velunderbyggede, men dr. Meier lægger dog ikke skjul på, at en del er omgivet af en vis usikkerhed. Især de mange arbejder i gruppen »tilskrevet H.R.« er udtryk både for denne velbegrundede usikkerhed, men også for forfatterens fornuftige forsigtighed.

Mange ting er taget $\mathrm{i}$ betragtning, når de enkelte arbejders tilblivelsessted nærmere skal bestemmes. De stilistiske kriterier behandles med rosværdig forsigtighed og suppleres så vidt gørligt med andre vidnesbyrd. Her er de skriftlige kilder vigtige og de inddrages udførligt. Dog benyttes nogle sekundære kilder som f.eks. Chr. Knudsens udskrifter måske for ukritisk. Væsentlig er også bestemmelsen af billedskærernes grafiske forlæg. Her er benyttet de væsentligste tyske behandlinger, men, selvom der ellers optræder både danske og svenske værker $\mathrm{i}$ litteraturlisten, så mangler et så centralt værk som Georg Garders værk om silkebroderede duge, der indeholder en væsentlig behandling af dette emne. Heller ikke de nyere skandinaviske ikonografiske artikler er benyttede. I litteraturlisten savnes også Erik Moltkes bog »Bernt Notke « med dens vigtige principielle diskussion om værkstedsorganisation. En lille fejl er en forveksling af den svenske Hans Rabén og den danske Jens Raben, hvis arbejder er slået sammen under een forfatter.

Denne bog er af interesse ikke blot for flensborgere eller for kunstin- 
teresserede i Tyskland. Også i Danmark og ikke mindst i Nordslesvig vil den have stor interesse. Ikke mindre end 34 af katalogets 114 numre befinder sig nord for den nuværende grænse, langt de fleste $i$ nordslesvigske kirker. Af disse er 5 sikre arbejder af H.R., 3 er i det mindste fra hans værksted, 11 tilskrives H.R. og endelig er 9 numre af en af H.R.-eleverne Jørgen Ringris eller Niels Tagsen. Der er således god grund til at anbefale bogen til alle, der ønsker at arbejde mere dybtgående med områdets kunsthistorie. Den er ikke letlæst, men den er grundig kyndigt skrevet.

J. Slettebo

Berend Harke Feddersen: Schleswig-Holsteinisches Künstler-Lexikon. Forlag: Nordfriisk Institutet, Bredsted 1984.

På grundlag af et kartotek på over 2000 kunstnernavne har Berend Feddersen, assisteret af kunsthandleren, dr.phil. Lilianne Grams og maleren Frauke Gloyer, udvalgt kunstnerne til optagelse i dette vigtige oversigtsværk. Heri er medtaget kunstnere, "der stammer fra SlesvigHolsten eller som har virket her $\mathrm{i}$ kortere eller længere tid «. Udeladt er alle de kunstnere, af hvem der ikke mere kendes arbejder, men som f.eks. kun kendes fra regninger, samt kunstnere med helt lokal betydning.

Disse kriterier medfører, at mange af dansk kunsthistories betydeligste kunstnere er omtalt, f.eks. malere som D.K. Blunck, Franziska Clausen, Balthasar Denner, C. W. Eckersberg, C. A. Jensen, Carl Locker og Peter Nicolaisen, og en billedhugger som H. V. Bissen. Desuden ses, at mange af de slesvig-holstenske malere uddannedes på Akademiet i København. Der er således tale om et kunstnerleksikon, der i høj grad også har dansk interesse.

Det vil altid være næsten umuligt at afgøre, hvad man bør tage med, og hvad man bør udelade $i$ et sådant leksikon. Her er en del taget med, som nok må siges at høre hjemme i udkanten af emnet. Det gælder en række kobberstikkere, lithografer og udgivere af prospekter og landskaber, som nok har stukket, lithograferet eller udgivet motiver fra Slesvig-Holsten, men som næppe selv nogensinde har været i området. Det samme galder flere kendte kort- og atlasudgivere som Homann, Merian og Speed, hvis kortværker nok omfattede hertugdømmerne, men hvor der som oftest blot var tale om let bearbejdede kopier. Mere uforståeligt er optagelsen af enkelte kunstnere som den norske 
Edvard Munch, der slet ikke ses at have haft nogen tilknytning til Slesvig-Holsten overhovedet.

$\mathrm{Nu}$ gør nogle ekstra optagelser ikke nogen skade. Værre er udeladelser, men her synes til gengæld ikke at være mange eller alvorlige mangler. Dyremaleren Gebauer, Christiansfeld-maleren Jeppe Madsen Olsen, og stukkatøren Tadei savnes, og der skal nok være enkelte flere, men som helhed forekommer navnerækken meget fyldestgørende. Blandt manglerne må også nævnes, at Albrecht Adam kun omtales som slagmaler og ikke som hestemaler, skønt han bl.a. udgav portrætter af hestene i det augustenborgske stutteri, at Heinr. Blunchs mange alsiske motiver ikke nævnes, selvom det var her han malede talrige bondegårde, og at V. Faurholt kun kaldes marinemaler, skønt han malede adskillige sønderjyske bybilleder og leverede tegninger fra krigen 1864 . Mens der ved de fleste malere henvises til museer i Slesvig-Holsten, Tyskland og evt. København, er der kun sporadisk henvisning til Sønderjyllands Kunstmuseum i Tønder, og kunstsamlingerne i Sønderborg og Aabenraa kendes åbenbart lige så lidt som andre danske provinsmuseer. Endelig kan der nok påvises huller i litteraturhenvisningerne, men iøvrigt er disses omfang imponerende stort.

Til trods for de nævnte mindre savn, der nok altid vil forekomme i værker af denne type, er dette leksikon med sine 200 siders koncentrerede oplysninger om kunstnere, udgivere, kartografer og andre virksomme indenfor kunstlivet i Slesvig-Holsten, en særdeles værdifuld håndbog. Her samles for hertugdømmerne en masse oplysninger, som ellers skal ledes frem $i$ en række forskellige og til dels svært tilgængelige danske og tyske opslagsværker. For alle, der arbejder med dette områdes kunsthistorie, er det blevet et storartet hjælpemiddel.

J. Slettebo

Brar C. Roeloffs: Von der Seefahrt zur Landwirtschaft. Ein Beitrag zur Geschichte der Insel Föhr.

383 s. Wachholtz Verlag, Neumünster 1985.

Øen Før har en glorværdig søfartsfortid, som har efterladt en rigdom af pragtfulde kommandørgravsten på øens kirkegårde, smukke huse, skibsportrætter osv. I dag er øen et søgt turistmål. Naturligt nok er litteraturen om Før - både den ældre og den nyere - derfor også betydelig. Roeloffs' bog er imidlertid noget for sig. Bogen beskriver den fundamentale udvikling i øens næringsliv fra søfart til landbrug, 
og det sker delvis gennem beretningen om den fremtrædende Roeloffsslægts historie. Resultatet er blevet en meget stor bog - og en særdeles smuk bog, med næsten 100 fine illustrationer, heraf flere pragtfulde farvebilleder. Det er en værdifuld, detailmættet beretning med mange nye oplysninger. Her kan kun gives en kort oversigt over indholdet.

Søfart var indtil begyndelsen af 1800-årene den vigtigste næringsvej. $64 \%$ af øens samlede befolkning var i 1769 tilknyttet søfarten. Hvalfangst ved Grønland var længe den foretrukne fart, men fra 0.1750 søgte flere og flere søfolk over $\mathrm{i}$ handelsfart med skibe fra Hamborg, Amsterdam eller danske byer. Søfolkene var et selvbevidst folkefærd, som nøje vågede over de privilegier, som var givet af den danske konge. Da der i 1781/821 kom ordre om, at søfolkene skulle lade sig indrullere, resulterede det nærmest $\mathrm{i}$ et oprør på øen. Roeloffs redegør detaljeret for oprørets forløb. Det er en interessant episode, som minder om andre samtidige folkelige protester mod øvrighedens indgreb i nedarvede rettigheder.

Efter den indledende almindelige redegørelse for søfartens betydning og udvikling berettes om en af øens succesrige søfolk, Diedrich Roeloffs (1753-1834). Faderen havde tjent på hvalfangerskibe fra Hamborg, og sønnen fulgte de første år $\mathrm{i}$ hans spor. Fra o. 1779 sejlede han - typisk for søfolkenes dispositioner på denne tid - på handelsskibe, først fra Amsterdam, fra 1781/82 som kaptajn fra København. Sejladsen på Middelhavet, hvor kaptajnen også havde mulighed for at drive egen handel, gav så stort udbytte, at han i 1795 kunne trække sig tilbage til Før med en betydelig kapital. Atter typisk for søfartens aftagende betydning investerede han nu i jord. Snart var han en af de største jordejere på Vesterlandfør, og han drev dertil betydelig købmandsforretning med krydderier og korn - øen var ikke selvforsynende. Han blev områdets rigeste mand. Bevarede journaler, brevbøger og regnskaber efterlader et enestående billede af landbrugsdriften, varehandelen og af en lokal matadors måske ofte skrupelløse udlånsvirksomhed. Insolvente debitorer måtte ofte overlade deres faste ejendom til Roeloffs - og han kom snart til at drive en omfattende ejendomshandel. I tilgift beklædte han talrige lokale tillidshverv.

Sønnen Christian Diederich Roeloffs (1801-85) førte forretningen videre. Manufakturvarer og kaffe blev nu de vigtigste varer, og købmanden virkede $\mathrm{i}$ praksis som lokalt bankinstitut: ydede lån af egen kapital, modtog lån, formidlede obligationer og pantebreve. Han drev også ejendomshandel, og landbruget blev udvidet til det største på Vesterlandfør - bl.a. ved overtagelse af jord og huse fra dårlige skyldne- 
re. Søfarten havde ikke længere større interesse - atter typisk for udviklingen. Som faderen beklædte også C.D. Roeloffs en mængde poster i det lokale selvstyre - han blev kaldt »kongen af Vesterlandfør«. Som god konservativ mand var han også positiv over for den danske administration, og han hilste de nye statsforhold efter 1864 med inderlig uvilje.

Bogen afsluttes med gode redegørelser for landbrugsdriften i 1800årene. Her drager skildringen nytte af gamle føringers fortælling. Også de særegne administrative forhold før de preussiske reformer, skolevæsenet og de politiske forhold behandles indgående.

Bogen vil med sin detailrigdom uden tvivl blive værdsat lokalt. Samtidig er den takket være det spændende og sjældne kildemateriale fra familien Roeloffs med til at belyse kapitalismens udvikling på den rige $ø$ i perioden 1800-1880. Analysen af de to Roeloffs-købmænd og bankmænds aktiviteter kunne nok være ført videre. Men bogen gør opmærksom på kilder, som forhåbentlig finder vej til offentlige samlinger, så de kan inspirere til videre studier - både hvad angår Vesterhavsøerne og andre egne.

Lars N. Henningsen

Lars N. Henningsen: Provinsmatadorer fra 1700-årene. Reder-, købmands- og fabrikantfamilien Otte i Ekernforde i økonomi og politik 1700-1770.

Udgivet af Studieafdelingen ved Dansk Centralbibliotek for Sydslesvig i kommission hos Rosenkilde \& Bagger, 1985, 472 sider, ill.

Ved et tilfælde blev arkivar Lars N. Henningsen interesseret i familien Otte, da den midt i det attende århundrede tilbød at beskæftige samtlige fattige i Slesvig og Holsten. Interessen medførte et forskningsprojekt med det formål at kulegrave familiens forhold i det hele taget. Dette blev muliggjort af et toårigt stipendium ved Studieafdelingen ved Dansk Centralbibliotek for Sydslesvig. Resultatet heraf præsenteres i den nu foreliggende bog.

Familien Otte fra Ekernførde har vist sig at udgøre et udmærket forskningsobjekt. Foretagendet voksede nemlig relativt hurtigt frem i årene omkring 1700, blomstrede derpå i en årrække for endelig at blive likvideret og få boet gjort op i årene efter 1766.

Virksomheden blev grundlagt af Christian Otte (1674-1747), som var søn af en skomager og startede helt fra bunden; men han fik 
opbygget et anseligt handelshus med rederi og erhvervede i 1735 desuden godset Kriseby i Svansen. Firmaet videreførtes af sønnen Frederik Wilhelm Otte (1715-1766), som gjorde rederiet til et af monarkiets allerstørste - medens brødrene og familien blot fungerede som temmelig passive investorer. Virksomheden omfattede $\mathrm{i}$ de gyldne år både rederi, skibsværfter, fajancefabrik, en række tekstilmanufakturer samt mel- og stivelsesfabrik. Desuden investerede familien $i$ andres virksomheder som for eksempel Asiatisk Kompagni i København og sukkerraffinaderi i Ålborg. Endelig anbragte den en del af kapitalen i jordegods, nemlig Kriseby, Binebæk i Siseby sogn ved Slien og Frederiksgave på Fyn.

De mangeartede aspekter af denne omfattende virksomhed har Lars Henningsen beskrevet indgående, og den er i sig selv en omfattende undersøgelse værd. Der er nemlig meget langt mellem monografierne over private handelshuse $\mathrm{i}$ det attende århundrede på vore breddegrader. Denne tingenes tilstand er blandt andet affødt af, at der stort set intet er bevaret af epokens private handelshuses arkiver. For Otternes vedkommende således kun en eneste protokol, som vedrører de juridiske forhold omkring godset Binebæk.

Lars Henningsen redegør indledningsvis for den danske og tyske litteratur, som ganske rigtigt er fragmentarisk og i høj grad centreret om hovedstaden. Dog ville forfatteren have kunnet fremdrage en rakke glimrende monografier om tidens nederlandske, franske og engelske handelshuse og rederier. Som et enkelt eksempel herpå skal blot nævnes Lucy S. Sutherland: "A London Merchant 1695-1774«, Oxford 1933 (optrykt 1962). Dette udmærkede værk er en biografi over William Braund, som var købmand, skibsreder, søassurandør med videre $i$ perioden fra 1741 til 1774 og en typisk repræsentant for englændernes aktiviteter.

Ifølge sagens natur har Henningsen først og fremmest vendt sig til det utrykte kildemateriale. Han har besøgt ikke mindre end femten forskellige arkivinstitutioner og i disse gennemarbejdet et imponerende stort og mangeartet kildemateriale. Som læser har man fuld tillid til, at den erfarne arkivmand har udtømt de relevante arkivfonds. Dette indbærer, at mange forhold kan beskrives i spændende detaljer. Men vel at mærke uden at hverken kildemængden eller detaljerigdommen tager magten fra forfatter eller læser. Bogen er klar disponeret, forsynet med stadige sammendrag og konklusioner, og den er dertil skrevet $\mathrm{i}$ et flydende og let læseligt dansk. Dette sikrer, at det er spændende og tankevækkende at følge med i Otte-familiens historie. 
Men den særlige værdi ved bogen er, at det har været en hovedtanke hos forfatteren at indsætte de fundne resultater vedrørende familien Otte $i$ en perspektivgivende og meningsuddybende generel ramme, overalt hvor det har været muligt. Således afrundes bogens hovedkapitler kompetent med afsnittene "Skibsrederen i perspektiv«, "Købmanden i perspektiv« og »Fabriksejeren i perspektiv«. Heri gør forfatteren forbilledligt opmærksom på, hvilke af de fremdragne træk ved Otterne, der er generelle, og hvilke der er specielle for denne familie.

Skibsfarten var og blev hjørnestenen for familien Ottes indtjening. I 1761 rådede rederiet da også over 24 skibe på tilsammen mere end 1.300 kommercelæster. Betragtet i perspektiv var dette en imponerende flåde: på størrelse med de største privatrederiers i hovedstaden $\mathrm{i}$ den florissante periode, og det vil sige Duntzfelt, Lars Larsen, Blacks enke og de Coninck! Frederik Wilhelm Otte skulle i sin samtid helt til Norge eller Hamborg for at finde sine ligemænd indenfor privat rederivirksomhed.

Foruden størrelsen var også ejerformen atypisk. Otte-rederiet var karakteriseret ved, at alle dets fartøjer tilhørte FR. W. Otte alene eller en snæver kreds af familien. Tilsvarende kapitalkoncentration kendes kun i visse af tidens norske foretagender så som den navnkundige Hans Hornemanns i Trondhjem.

Med hensyn til repræsentativitet var Ottes flådes erfaringer med konjunkturerne for udenrigsfarten derimod helt fælles med al anden dansk-norsk søfart på fremmede destinationer. Særlig tydeligt slog disse konjunkturer igennem under Store nordiske Krig og Den preussiske Syvårskrig eller Kolonikrigen, hvor de neutrale skibe kunne opnå glimrende fragtrater og drive særlig indbringende egenhandel.

Foruden disse internationale konjunkturer må man dog også huske på, at især efter den slesvigske inkorporation i 1721 løb familien Otte ind $i$ visse problemer som følge af det nye danske tilhørsforhold. Som et led i styrets merkantilistiske politik favoriseredes København handelsmæssigt på mange måder i forhold til provinsen. Tænk blot på forordningen om de fire species i 1726, toldloven i $1735 \mathrm{og}$ kommerceforordningen i 1742. På den anden side havde Otte-rederiets skibe god gavn af, at regeringen for eksempel sluttede traktater med en række nordafrikanske kaperstater - og derved i realiteten åbnede Middelhavet for undersåtternes søfart fra slutningen af 1740erne.

Såvel push-effekten i form af restriktioner hjemme som pull-effekten i form af gunstige konjunkturer ude fik Otterne til at slå sig på rederi og fragtfart for fremmed regning. I ly af J. H. E. Bernstorffs traktatpoli- 
tik og neutralitetsværn skummede rederne fløden; i så henseende hørte Fr. W. Otte til de driftigste og dygtigste. Hovedaktiviteten var fragtfart med tømmer og korn fra Østersøen til Portugal, Spanien og senere Middelhavet. Derimod var returfragterne af salt og vin mindre indbringende. Og kun sjældent gik Otte aktivt ind i selve handelen med egne varer. Dette hænger blandt andet sammen med det forhold, at trods de omfattende aktiviteter var den likvide kapital begrænset, idet næsten alle penge var bundet $\mathrm{i}$ familierederiets mange skibe.

Den specielle fart mellem Balticum og Sydeuropa udgjorde som sagt grundlaget for alle familiens aktiviteter. I de mange udmærkede bilag kan den interesserede blandt andet følge flåden, skipperne, ladningerne og sejlruterne. Især er dette muligt i det omfattende bilag 21 , så det fuldstændige baggrundsmateriale hertil er deponeret $i$ både Landsarkivet i Åbenrå, Handels- og Søfartsmuseet på Kronborg og Schiffahrtsmuseum i Flensborg. Navnlig i spørgsmålet om skibenes faktiske sejlmønstre, eksempelvis i Middelhavet, har Lars Henningsens findekunst ført ham vidt omkring $i$ arkivmasserne med et fint resultat til følge.

Købmandskab og egenhandel havde haft nogen betydning for Christian Otte, medens sønnen Frederik Wilhelm Otte kun drev en relativt beskeden engroshandel. Denne bestod af import af tømmer, jern og kalk fra Østersøområdet og vin fra Frankrig; hertil kom en vis transithandel mellem fremmede havne med fremmed korn. Dette mønster ligner meget det, vi kender for eksempel for Flensborgs vedkommende på samme tid. I øvrigt går Henningsen ikke dybt ind i netop handelsvirksomheden.

Derimod bringer han et stort kapitel om fabriksejeren Fr. W. Otte og hans kreds. Her gennemgås de mange foretagender, som Ottekapitalen blev involveret i fra $1754 \mathrm{og}$ fremefter. Der var dels fajancefabrikken, kniplingstrådfabrikken og kammerdugsfabrikken, der alle var organiseret som aktie- eller interessentselskaber med flere parthavere. Dels var der brødrene Ottes helt egne virksomheder, nemlig uldmanufakturet, der først lå i Binebæk og siden i Ekernførde, fajancefabrikken, først på Kriseby derpå også i Ekernførde, samt mel- og stivelsesfabrikken på Kriseby.

Flere af foretagenderne var af anselig størrelse. Således blev uldmanufakturet indrettet i 7 nyopførte fabriksbygninger ved Kakabillebækken, hvor der arbejdede 80 mennesker, foruden 150 hjemmespindere i omegnen. Hermed hørte foretagendet til blandt de største private i den danske provins. 
Problemet med fabrikkerne var imidlertid det grundlæggende, at deres varer ikke var konkurrencedygtige overfor importvarer, fordi de var for dyre og/eller for dårlige. I familien Ottes tilfælde gav kun kniplingstrådfabrikken et vist afkast.

Da investeringerne i fabriksvæsenet var temmelig store, synes det mærkeligt, at den ellers så udpræget husholderiske og hurtigt reagerende Fr. W. Otte vedblev med at pumpe penge i disse urentable foretagender. Lars Henningsen fremfører to forklaringer herpå, som begge synes plausible. Enten var det, fordi Otte var præget af tidsånden og overbevist om, at investeringerne snart ville lønne sig, eller også var det, fordi styret i København så med særdeles milde øjne på de undersåtter, som fremmede fabrikker og manufakturer. Sandsynligvis må den første forklaring tillægges afgørende vægt; men den sidste har givetvis også spillet en vigtig rolle for Otte. Ikke fordi han skulle opnå store statslige subsidier, thi sådanne fik han faktisk aldrig nogen af - han finansierede som nævnt sine foretagender ved hjælp af egne midler fra fragtfarten. Men fordi navnlig forholdet til J. H. E. Bernstorff spillede en stor rolle for Otternes samlede virksomhed.

En af grundene til, at Otte havde Bernstorffs bevågenhed, var sikkert, at i Otte personificeredes en af den fabrikvenlige Bernstorffs ønskedrømme: at de handlende skulle anvende en del af deres kapital som industriforlæggere. Men skønt den industrifremmende orotodokse merkantilistiske politik netop kulminerede under Bernstorffs tid i Kommercekollegiet fra 1752 til 1766, var det sjeldent, at handelsfolk ville gå ind i projekterne. Måske fordi Bernstorff havde en ulyksalig tendens til at forbeholde statsstøtten til mere fantasifulde end realistiske udenlandske projektmagere.

Foruden at lede Kommercekollegiet var Bernstorff det dominerende medlem af geheimekonseillet (den reelle regering i Frederik Vs tid), og han ledede Tyske Kancelli (udenrigsministeriet).

I denne sidste egenskab kom J. H. E. Bernstorff også i forbindelse med Fr. W. Otte. Under den alvorlige udenrigspolitiske krise i 1762 mellem Danmark-Norge og Rusland $\mathrm{i}$ anledning af det uafklarede gottorpske spørgsmål kom Otte til at spille en afgørende rolle. I kraft af den anseelse, han havde vundet hos Bernstorff på grund af sin økonomiske indsats, kunne Otte skabe kontakt mellem sin ven Caspar von Saldern og udenrigsministeren. Otte og von Saldern ønskede begge brændende at undgå den truende dansk-russiske krig. I modsætning til den tidligere forskning på området påviser Lars Henningsen den meget aktive og betydningsfulde rolle, som Otte spillede, og som var en 
nødvendig betingelse for, at von Saldern kunne fungere som Bernstorffs hemmelige fredsagent i Sankt Petersborg, samt at han senere kunne påskønnes økonomisk derfor.

Foruden de nævnte centrale temaer behandler bogen om Otterne en række andre interessante spørgsmål. Blandt andet giver Henningsen et rids af livsholdningen og privatlivet, af problemerne ved at have en gigant som Otte $\mathrm{i}$ en lille by som Ekernførde og så videre. Alt $\mathrm{i}$ alt får vi en mangefacetteret, interessant og veloplagt skildring af, hvad forfatteren med et af sine mange moderne udtryk kalder provinsmatadorerne i Ekernførde.

Vi får præsenteret et familiebillede med Frederik Wilhelm Otte i en stærkt dominerende rolle. Han var manden med den gode udgangsposition, initiativet og de præcise fornemmelser for, hvad der bedst kunne satses på i rederiet. Hans indstilling mindede på mange måder om en moderne kapitalistisk forretningsmands, og virksomheden var i mange henseender et foregangsforetagende.

Ved sine engagementer $\mathrm{i}$ manufakturdrift og fabrikker vandt han efterhånden J. H. E. Bernstorffs bevågenhed. Om egentlig belønning fra styrets side blev der imidlertid aldrig tale. Otterne sad for langt fra magtens centrum i København; men ved eget initiativ og dygtighed vandt familievirksomheden en enestående succes. Dog skinner det tydeligt igennem flere gange, at Fr. W. Ottes gode forbindelse til Bernstorff affødte en række væsentlige fordele for firmaet. Otte benyttede sig flittigt af sine forbindelser $\mathrm{i}$ et nærmest patron/klient-agtigt forhold. I dette tilfælde som i så mange andre fra tiden bemærker vi det yderst komplicerede samspil mellem statsinteresser og privatinteresser.

Successen stod og faldt med Fr. W. Otte selv, og straks efter hans død i 1766 besluttede den efterladte familie af lade firmaet likvidere og gøre boet op. Efter Lars N. Henningsens kvalificerede skøn må formuen på dette tidspunkt have været på mindst 200.000 rigsdaler, hovedsagelig indtjent ved rederivirksomheden.

Efter 1766 blev skibsflåden afviklet, godserne og aktieposterne blev solgt, medens handelsvirksomheden til dels blev fortsat. Fabrikkerne derimod var faktisk usælgelige - under boafviklingen lige som tidligere var og blev de smertensbarnet.

Otte fik aldrig beskæftiget alle de fattige i Slesvig og Holsten i sine fabrikker. Men Lars Henningsen fik vakt sin nysgerrighed og har fået skrevet en fremragende bog om familiens mange aktiviteter. 
Georg Alfred Runge: Das Königliche Appellationsgericht für das Herzogtum Schleswig in Flensburg 1852-67.

Kiel 1985. 287 s. + registre, ill.

Det er godt, at de fleste danske og tyske Sønderjyllands-forskere i dag kan se nogenlunde uhildet på begivenhederne under den hårde nationale strid i 1800 -tallet. I lang tid var det meste af, hvad der blev skrevet om det gamle hertugdømme, tydeligt nationalt præget, også hos dem, der prøvede at give redelig og objektiv oplysning.

Forfatteren til denne bog synes fri for sådanne fordomme. Han fødtes i Dresden 1917, tog juridisk eksamen i Østtyskland 1955 og virkede derovre til 1979, hvorefter han flyttede til Vesttyskland. Han bor nu i Harreslev. For bogen her fik han i 1985 en juridisk doktorgrad ved Kiels universitet.

Emnet er den appellationsret, den danske regering efter treårskrigen 1848-50 oprettede som øverste instans for hertugdømmet Slesvig, adskilt fra retsvæsenet i Holsten, - en institution, som indtil for få årtier siden på tysk side $\mathrm{i}$ almindelighed enten kritiseredes temmelig stærkt eller også omtaltes helt kort som en uinteressant overgangsordning. Runge vil med sin bog yde denne domstol retfærdighed ved en saglig skildring af dens tilblivelse og dens virke i det korte åremål, inden den blev ophævet af projserne.

For en mand, der først bosatte sig i Slesvig som pensionist, måtte det være et stort arbejde at sætte sig ind i forholdene her, så han kunne gå $\mathrm{i}$ gang med en sådan opgave. Foruden at læse en mængde tyske bøger og arkivstof om emnet lærte han så meget dansk, at han kunne studere en række danske værker foruden håndskrevne dokumenter $\mathrm{i}$ Rigsarkivet i København. Bogens register over tyske og danske arkivalier og bøger vidner om stor flid i de få år, Runge har haft til dette arbejde, og han fortæller om en masse enkeltheder - helt ned til knapperne på dommernes uniformer, som tildels havde den danske højesterets som forbillede.

Forstudiernes store omfang og den tidnød, Runge må have været $i$, giver en rimelig forklaring på, at der kan spores enkelte huller $\mathrm{i}$ hans læsning og dermed $\mathrm{i}$ forståelsen af visse forhold. Stoffet kunne også på visse punkter være behandlet noget strammere og derved mere overskueligt, og der er - vel tildels på grund af utilstrækkelig korrekturlæsning - ret mange fejl, dog oftest mindre væsentlige. Men alt i alt skal Runge have ros for bogen. Den viser, at appellationsretten stort 
set løste sin ganske vanskelige opgave særdeles respektabelt, og rummer i tilgift mange interessante detailler.

Det ville have lettet forståelsen hos tyske læsere, hvis det korte afsnit om retsforholdene før 1848 havde nævnt, at herredet er en gammel nordisk administrativ og retslig inddeling, som ikke kendes syd for Ejderen, og at Slesvig - i hvert fald til 1658 - var et dansk len og aldrig før 1864 havde hørt til det tyske rige. Runge omtaler, at Frederik VI i 1834 oprettede en stænderforsamling for Slesvig og en for Holsten og samtidig som noget nyt indførte en fælles regering på Gottorp og en fælles overappellationsret i Kiel som 3. instans for begge hertugdømmer, så den i 1713 oprettede overret på Gottorp nok stadig virkede som 2. instans, men ikke længere var øverste domstol for Slesvig. Men han udtrykker ikke som professor Kurt Jürgensen, hvis artikel fra 1984 om overappellationsretten han har læst, forbavselse over, at den enevældige konge gik med til dette nye fællesskab mellem hertugdømmerne, som han tidligere havde sagt nej til. Det knyttede jo det danske hertugdømme Slesvig endnu tættere til det tyske Holsten og prisgav den vigtigste danske landvinding ved den store nordiske krig, da hele Slesvig fik sin egen overret og regering på Gottorp, adskilt fra Holsten.

Bogen fortæller udførligt om de midlertidige ordninger af Slesvigs øverste retsvæsen fra 1850, da den særlige slesvigske overret på Gottorp ophævedes, og overappellationsrettens kompetence for Slesvig afskaffedes, til 1/6 1852, da den nye appellationsret kunne begynde sit arbejde i det loyale Flensborg, som nu blev sæde for alle hertugdømmets højeste embedsmænd.

Der berettes grundigt om den nye domstols virke, herunder dens personale. Den var ikke så ringe, som visse tyskere har påstået. Præsidenten C. L. E. Stemann (1802-76), der var født i Husum, ledede rettens arbejde på fremragende vis og gjorde bl.a. også en højt værdsat indsats som retshistorisk forfatter, efter 1864 med bopæl i København. Den flensborgske dommer Johannes Meyer skrev for et par år siden en udmærket artikel om Stemann med stor respekt for ham. Der skete vist ikke nogen uret, da han blev foretrukket som præsident fremfor den fortræffelige flensborger, professor Christian Paulsen, der sad i den øverste domstol for Slesvig fra 1850 til sin død 1854. Stemann og alle rettens andre dommere blev afsat uden pension af prøjserne i marts 1864, da de ikke ville aflægge ed på ubetinget lydighed over for de nye magthavere. De rejste alle nordpå, hvor de gennemgående endte $i$ vigtige embeder, herunder 3 som dommere i Højesteret. Runge nævner 
her kun Werner Ussing og Fritz Meyer og er måske ikke opmærksom på, at Hother Smith kom i Højesteret i 1874. I denne forbindelse ses bogens mest overraskende fejl, der nok skyldes sprogvanskeligheder. Der står, at dommer Chr. Juel senere i København kom i bestyrelsen for »Kreditkasse für Grundeigentum in Fernost«. Det må være »Kreditkassen for Landejendomme i Østifterne«.

I sin beskrivelse af rettens arbejde omtaler Runge også dens virksomhed som eksamenskommission 1851-64 for unge jurister, der ville tage den særlige slesvigske embedseksamen. Efter hans vurdering stod rettens virke $i$ civile og kriminelle sager fuldt på højde med det arbejde, der udførtes af den holstenske overappellationsret i Kiel. Han fremhæver også, at retsplejen i Slesvig efter 1850 blev hurtigere end før. Da de danske dommere, hvoraf ca. halvdelen var født i hertugdømmerne, den 19/3 1864 måtte standse deres virksomhed, synes der ikke at have været restancer (Rückstände), men dog formentlig løbende sager under planmæssig, hurtig behandling.

Der udnævntes nu nye tysksindede dommere; men indtil 1867 fortsatte appellationsretten iøvrigt på mange måder sit arbejde i Flensborg temmelig uændret, bortset fra, at det snart danske, snart tyske retssprog fremtidig kun var tysk. Så indførte en forordning fra Berlin en ny prøjsisk retsforfatning fælles for de to hertugdømmer, fremtidig provinsen Slesvig-Holsten. Appellationsretten for Slesvig forsvandt, og Flensborg fik nu som 2. instans kun en »kredsret« (fra 1879 Landgericht) med appel til provinsens fælles appellationsret i Kiel (fra 1879 overlandsretten, der nogenlunde svarer til en landsret $i$ Danmark). Den stod igen under Prøjsens højesteret, Oberappellationsgericht i Berlin. Fra 1879 var højeste instans det tyske kejserriges rigsret i Leipzig.

Runge viser også stor interesse for den bygning, appellationsretten sad i til 1867 i sydfløjen af det regeringskompleks, som efter 1850 opbyggedes i Flensborg i en smuk gammel købmandsgård på Holmen. Byggeriet lededes af Flensborgs stadsarkitekt L. A. Winstrup (181589). Efter det klassiske magtdelingsprincip rummede det samlede bygningskompleks et særligt Stænderhus for stænderforsamlingen (parlamentet), nordfløjen med den slesvigske regerings forvaltning og så sydfløjen med retssale m.m.; dette svarer iøvrigt til fordelingen i de tre led af det nogle årtier senere nybyggede Christiansborg i København. Runges fremstilling bygger her $\mathrm{i}$ stor udstrækning på en udmærket skildring af Winstrups bygningsarbejder i Sønderjylland, skrevet af Erik Bondo Svane (1911-45) og trykt i Sønderjyske Årbøger 1946. Det fortælles bl.a., at det danske rigsvåben og ordene "Med Lov skal Land 
bygges« fra Jyske Lov, som delvis gjaldt i Sønderjylland lige til 1900, blev fjernet fra retsbygningen (vist i 1867) og erstattet med Prøjsens ørn. Men det kendte store maleri af Lorenz Frölich »Valdemar Sejr giver Jyske Lov« hænger stadig i Flensborg Landgerichts sal i den nyere retsbygning i Søndergravene.

Efter 1883 blev Winstrups regeringsbygninger ved Holmen hovedsagelig brugt som byens rådhus, også under den danske overborgmester I.C. Møller 1945-51. Runge beklager meget, at bystyret i 1964 lod disse spændende bygninger nedrive til grunden for at give plads for det åndløse varehus Hertie.

Frants Thygesen

Frithjof Löding: Theodor Storm und Klaus Groth in ihrem Verhältnis zur schleswig-holsteinischen Frage. Dichtung während einer politischen Krise.

Quellen und Forschungen zur Geschichte Schleswig-Holsteins. Bind 84. Neumünster 1985, 214 sider.

F. Lödings værk om slesvigeren Storms (1817-1888) og holsteneren Groths (1819-1899) stillingtagen til det "slesvig-holstenske spørgsmål« er en dissertation fra universitetet i Kiel. Forfatterens hovedformål er en litteraturteoretisk og historisk-politisk analyse af begge digteres lyriske værker fra 1840erne og 1864 ff. Löding beskriver digternes kunstteoretiske overvejelser og gør rede for, hvordan digtene nærmer sig eller fjerner sig fra den rene "forfatterkunst « - l'art pour l'art - og hvor de kommer til at ligne politisk journalisme. Han skildrer den historiske situation, der gav stødet til digtenes tilblivelse, og afdækker ved flittig brug af biografisk kildemateriale, især breve, de to digteres politiske eller apolitisk-egoistiske, opportunistiske, motiver. Således lykkedes det at tyde digtenes politiske budskab og at tolke digternes reaktioner på et samfund, der var gennemsyret af nationale modsætninger og borgerskabets liberale reformkrav.

Metoden gennemføres konsekvent og overbevisende.

Bogen indledes med et rids over Slesvig-Holstens historie i første halvdel af 1800-tallet. Denne baggrundsskildring gengiver stort set den gangse slesvig-holstenske opfattelse af Slesvigs historie. F. Löding viser under sit analyserende arbejde og $\mathrm{i}$ sine vurderinger dog en større forståelse for det danskes hjemstavnsret i Slesvig, især naturligvis "Nordslesvig", end man kunne forvente. Han synes desværre at mangle 
danske sprogkundskaber, ellers ville han have opdaget Anna Simonsens lille, men relevante afhandling "Theodor Storm og Danmark" (Sdrj. Årbg. 1950, s. 140-52), der i store træk bekræfter hans egne resultater: Storms drøm havde været et uafhængigt Slesvig-Holsten, frit for enhver fremmed indflydelse, hvad enten den kom fra nord eller fra syd. Hele hans digteriske produktion bærer vidnesbyrd om hans dybe kærlighed til hjemstavnen. Han var, som han et sted kalder sig selv, "sin hjemstavns mest trofaste søn! (A. Simonsen, s. 142, 151, 152). F. Löding når imidlertid til et langt mere differentieret billede end A. Simonsen.

I to afsnit (Storm s. 36-133 og Groth s. 134-197) gennemgås digte og enkelte prosatekster, som omhandler eller strejfer emnet den tyskdanske modsætning: den slesvig-holstenske »rejsning «, det danske herredømme over Slesvig, krigen 1864 og hertugdømmets indlemmelse i Preussen. I et afsluttende kapitel drøftes fællestræk og forskelle i de to digteres holdninger.

Storm og Groth holdt fast ved en æstetisk tradition, der hyldede »den rene digtekunst «, hvis indhold er de evige, almengyldige værdier. Begge digtere afviste enhver form for politisk tendenslitteratur: "Wenn Schwerter klirren, sind es nicht Gedichte .... (Storm). Men de levede $i$ en tid med store omvæltninger på det samfunds- og nationalpolitiske felt. Hverken Storm eller Groth kunne unddrage sig den opblussende tysk-danske modsætning, den fandt genlyd i deres digte. De to digteres æstetiske krav førte imidlertid til, at begge undlod at reflektere over de historisk-politiske forhold: Storm og Groth fornægtede i deres værk de modstridende parters relative ret i kampen om Slesvig, de ophøjede deres egne tysk-nationale krav til en historien indeboende naturkraft og gav dem derved et skær af »almengyldighed «. Især Storms digte fik en stærk propagandistisk slagside.

Begge digtere var tysksindede. Den politiske naive Groth blev båret af 1840ernes nationale opbrudsstemning, hans nærmest upolitiske holdning medførte, at han under Treårskrigen kunne se lidende mennesker på begge sider af fronten. Th. Storm var derimod en i høj grad politisk engageret borger, han var nationalliberal slesvig-holstener og ønskede et uafhængigt, demokratisk Slesvig-Holsten. Danskerne - og også de danske slesvigere - var for ham kun »de fremmede«, der ville erobre hans tyske hjemstavn. Selvom han efter 1864 kunne forliges med Slesvig-Holstens indlemmelse i den tyske stat Preussen, blev han til en preusserhader. Storm afskyede det reaktionære preussiske regeringssystem, "das Junkerregiment «, og de nye magthaveres voldsherre- 
dømme. Han ligestillede endda preusserne med danskerne: de var trængt ind $i$ landet og forhindrede hans hjemstavns udvikling $i$ borgerlig-liberal retning. Han mødte den tysk-franske krig 1870-71 og indstiftelsen af det tyske kejserrige med kritik - og opdagede i disse år de danske slesvigeres nationale selvbestemmelsesret! K1. Groth affandt sig nok så hurtigt med den ny situation og bekendte sig efter 1871 til den preussiske stat. Men begge digtere trak sig efterhånden resigneret tilbage fra det politiske liv og søgte i det kunstneriske arbejde at leve op til kravet om en litteratur, der var hævet over dagens politiske strid.

Frithjof Lödings vellykkede afhandling giver læseren et godt indblik $i$ to forfatteres værk fra en politisk krisetid.

Johann Runge

Barn og ung i Sydslesvig 1900-1982. Bind I \& II. 1986. red. af Jørgen Hamre og Johann Runge.

Udgivet af Studieafdelingen ved Dansk Centralbibliotek for Sydslesvig. I kommission hos Rosenkilde og Bagger. 510 sider, indb., ill.

"Humor er egentlig ikke sydslesvigernes stærke side«, skriver Fr. Mommsen i "Barn og ung i Sydslesvig 1900-1982«. Men heri tager han fejl. Det viser han selv, og det viser mange andre i det dobbeltbind, som Dansk Centralbibliotek for Sydslesvig udgav ved årets start.

Bøgerne viser også, at den sydslesvigske erindringslitteratur nu rigtig er kommet på vej. Hvad der startede som enkeltpersoners bidrag, har efterhånden udviklet sig til at blive samlede værker med bidrag fra en lang række wikke-litterære « personer - dvs. fra personer, som nok er kendte i den sydslesvigske hverdag, men mere som forenings- og skolefolk og mindre for deres skrivende aktiviteter. Det betyder derfor også, at der $\mathrm{i}$ højere grad lægges vægt på dagligdags beskrivelser og mindre på generelle reflektioner.

Det gælder specielt »Barn og ung i Sydslesvig 1900-1982«, og det er bøgernes styrke - men $i$ visse henseender også en svaghed.

Når det er bøgernes styrke skyldes det, at mange oplevelser bliver mere nærværende, men især får det betydning for forståelsen af de reaktioner og handlingsmønstre, som vi kender symptomerne på, men hvis årsager har været mere eller mindre ukendte.

"Vi var mange, der var danske, men dansk kultur og dansk måde at leve på, det kendte vi intet til«, skriver tidligere bibliotekar ved Centralbiblioteket Fr. Mommsen. Det er måske bøgernes vigtigste 
tema. Det går igen i de fleste indlæg, at mange af skribenternes forældre var tilknyttet det danske arbejde - eller blev tilknyttet det i 1920 eller 1945 og tiden der fulgte - uden at være sig bevidst, hvad man forstod ved at være dansk og hvorfor man følte sig dansk. " Som barn troede jeg, jeg var tysk «, skriver W. L. Christiansen. Men i dag er han dog mblevet til en nogenlunde dansk mand«.

Bente Hillebrecht er en af dem, der mest konsekvent diskuterer dette problem. For hende skyldes det først og fremmest den nære kontakt med folk nordfra, at mange sydslesvigere blev sig deres danskhed bevidst. Men det spillede også en afgørende rolle, at den tyske omverden reagerede så voldsomt overfor alt dansk, en reaktion som gjorde sig gældende indtil 1950'erne.

Det tyske tryk avlede modtryk, dvs. skabte et sammenhold og en fælles dansk identitet og bevidsthed, skriver da også mange af forfatterne. Bente Hillebrecht mener derfor, at det $\mathrm{i}$ dag er blevet sværere for de unge at forstå, hvad der er specielt dansk, når den tyske omverden er blevet mere forstående overfor det danske, ja, vi bliver »ligefrem respekteret«, skriver hun. Børn og unge vil i dag ikke med samme selvfølgelighed kunne finde deres nationale ståsted.

W. L. Christiansen fortæller, hvorledes hans far fortrød, at han ikke havde sendt sin søn i dansk skole. Da han var ansat ved tysk kommunal institution, så stred det mod hans sans for loyalitet, hvis hans barn skulle $i$ en dansk skole. Men da han alligevel blev afskediget i 1933 fordi han var dansksindet og derfor politisk upålidelig - så fortrød han, at sønnen var kommet $i$ tysk skole og ikke $i$ en dansk.

Hvor mange har ikke været i den samme situation? Det var vel netop en stor del af de mennesker, som var baggrunden for den store og voldsomme opblomstring for den danske bevægelse efter 1945. W. L. Christiansen skriver da også, at man i hvert fald opnåede én ting i 1933: "... at det på grund af kravet om »Ariernachweis« gik op for mange, hvor deres familier kom fra! «

De to bind dækker perioden fra 1900-1982. Men det er dog ret ujævnt. Langt den største del af stoffet skildrer 1930'erne og 1940'erne, og det er egentlig en skam. Her kunne redaktørerne godt have grebet lidt mere styrende ind. Men til gengald giver det muligheder for at sammenligne de forskellige oplevelser. Og de viser da alle den samme tendens: kampen for det daglige brød, kampen mod myndighederne, kampen mod flygtningene, kampen mod tyske unge, når man er på vej hjem fra skole, den lange skolevej til specielt Duborg-skolen osv. $\mathrm{Ja}$, egentlig er det ret fantastisk, at der trods alt var så mange, der var 
trofaste overfor det danske arbejde - før 1945! Men selv om det var hårdt, er der ingen som beklager deres barndom. Tværtimod fremtræder den ofte $i$ et måske for idylliserende skær?

Det ville måske nok have gjort indholdet endnu mere spændende, hvis flere af forfatterne oprindelig havde været tyske. Men de har alle deres rødder »i orden « - eller giver i hvert fald udtryk for det: kun få oldeforældre kommer fra Holsten!

Når årstallene ofte er lidt misvisende, hænger det også sammen med, at flere indlæg næsten fortæller mere om forældrene end om sig selv. Og mange gange gør de alt for meget ud af deres tidligste barndom, som de alligevel ikke rigtig kan huske noget fra, men hvor det da $i$ højere grad bliver genfortælling af andres oplevelser, hvad andre har fortalt. Derved mister det noget af sin kilde-værdi.

Det er måske derfor, at f.eks. Anders Ture Lindstrøm kalder sit bidrag for "Erindringer i utide»? Det behøver han i hvert fald ikke, selv om også han starter med forældrene og sine yngste år. Men måske hentyder han til, at mange forhold $\mathrm{i}$ barndommen og ungdommen ikke opleves og forstås i nogen større sammenhæng? Anders Ture Lindstrøm fortæller f.eks. selv, at han ikke nåede at registrere »den gradvise dansk-tyske afspænding efter 1955 $\ll$. Til gengæld forholder han sig til sin egen fortid. Den registreres ikke blot, men den bearbejdes. Og det burde andre indlæg også have gjort i større udstrækning. Nogen skriver simpelthen for meget og som regel for registrerende og genfortallende. Her mener jeg også, at en kraftigere redaktionel beskæring ville have været på sin plads. Det gælder især Hans Werner Hansens næsten 90 sider lange indlæg, hvor der er så mange gode historier - men altså også en del, der er til overs.

Men »Barn og ung i Sydslesvig 1900-1982« har været utrolig god og spændende læsning. Dels fordi man får så meget at vide, men også fordi man på den ene side er ved at få latterkrampe, og få sider senere sidder med en stor klump i halsen. Det gælder især Gerhard Ernst's meget fine bidrag. Men bøgerne har også været en stor oplevelse, fordi de med Hedvig Lorenzens ord fortæller os, hvad det er der giver "livet indhold: kærlighed til fædrelandet, frihedsidealer, tolerance og respekt for anderledes tænkende«. Og som Meta Lorenzen skriver, så er det ofte også forhold, som tilsyneladende ingenting er, som er med til at give et menneske identitet.

Disse bøger fortjener stor udbredelse og er oplagte gaveemner til næsten enhver lejlighed. 
Gabriele Stüber: Der Kampf gegen den Hunger 1945-1950. Die Ernährungslage in der britischen Zone Deutschlands, insbesondere in Schleswig-Holstein und Hamburg.

Studien zur Wirtschafts- und Sozialgeschichte Schleswig-Holsteins. Bind 6. 934 sider. Karl Wachholtz Verlag, Neumünster 1985.

„Erst kommt das Fressen, dann kommt die Moral«. Således indleder Dr. Gabriele Stüber sin massive afhandling om krise- og hungerårene under den britiske besættelsespolitik i Sydslesvig, Holsten og Hamborg, der forsyningsmæssigt blev administreret sammen i de første efterkrigsår. Perioden 1945-1950 har dermed fået et væsentligt nyt bidrag til belysningen af de sociale og økonomiske vilkår. 934 sider tekst, litteraturhenvisninger og noter er meget, måske også en anelse for meget. Til gengæld er bogen både velskrevet og veldokumenteret og dermed et godt arbejdsinstrument både for forskere og lagmænd, der måtte interessere sig for denne bevægede tid. Det skal tillige fremhæves, at Gabriele Stübers skildring af den bevægede besættelsesperiode går lidt videre, end den traditionelle konservative officielle slesvig-holstenske fortolkning af samtidshistorien. Samtidshistorien er ikke noget harmløshedens evangelium, Gabriele Stüber gør i flere sammenhænge klart opmærksom på nogle af de politiske problemstillinger efter 1945, der ellers nødigt nævnes syd for grænsen. Der er iøvrigt også i et vist omfang gjort brug af dansk kildemateriale og forsøgt en lidt mindre firkantet fortolkning af begrebet "Speckdäne« efter 1945.

Selv om den ældre tyske historikergeneration ikke kan lide at høre det, så betød den tyske katastrofe i 1945 kaos og opløsning, moralsk og politisk, en naturlig følge af den totale krigs totale nederlag. De allierede besættelsesmagter befriede også tyskerne fra nazismen, men det var uundgåeligt, at nazitiden måtte få varige svære følger for det tyske folk og samfund. Specielt de første besættelsesår var ikke særlig behagelige for tyskerne, og det er ikke så sært, at det har taget tid at trænge igennem med forskning på dette væsentlige område af det tyske folks sociale og økonomiske fornedrelse.

Under krigen havde de besatte landes folkeslag måttet sulte og arbejde for den nazistiske krigsmaskine, hundredtusinder gik til af sult, bl.a. i Holland og Grækenland. Tyskerne var ingenlunde klare over, hvor upopulære eller forhadte, de var blevet. De første års besættelsespolitik med et lavt kalorieniveau kostede tusinder af menneskeliv, men hvad fik man mon at spise i Østeuropa og på Balkan? De fordrev- 
ne flygtningemasser fra øst gjorde det ikke bedre. Ruinkriminaliteten florerede, røverbander plyndrede levnedsmiddellagre. Spædbørn og ældre var særlig udsatte for sult og kulde. Skrap rationering og militærjustits kunne ikke hindre det sociale forfald, unge og flygtninge blev kriminelle for at overleve. Landmænd i Sydslesvig og Holsten levede højt på at forsyne byernes befolkning med sortbørsvarer. Uden sortbørs havde samfundet sandsynligvis fungeret endnu dårligere.

Endnu i 1950 var 60-70\% af alle skolebørn i dårlig ernæringstilstand, især flygtningebørn var elendigt stillede.

Gabriele Stüber understreger sultens virkninger på de besatte tyskere: når man lever på 1300 kalorier, tænker man ikke på krigsskyld og afnazificering, men på at overleve. Og siden blev de jo hurtigt trætte af at gå i sæk og aske.

Gabriele Stüber skildrer udførligt den britiske besættelsesmagts problemer med at ernære den britiske zone og skriver anerkendende om de store britiske ofre for at holde tyskerne nogenlunde i live. De valutahungrende briter, der selv tidligt måtte genindføre rationering, var nødt til at købe mad til tyskerne til dyre verdensmarkedspriser. Det burde man kunne se lidt mere om i en normal tysk historiebog. Udenlandske hjælpeorganisationers omfattende støtte beskrives detaljeret, derunder også Sydslesvighjælpen. Efter forfatterens opfattelse havde Sydslesvighjælpen nok et dansk-politisk sigte, selv om det ikke glemmes, at også betydelige tyske kredse nød godt af fødevarehjælpen. Glemt bliver heller ikke de mange tyske flygtninge i Danmark. Men mange historiske myter lever stærkt, det ville derfor være hensigtsmæssigt at få en nøgtern og kølig redegørelse for hele den danske fødevarehjælp til samtlige tyske områder.

Der er mange spændende emner at tage fat på $\mathrm{i}$ vor sydlige nabos nyeste historie, fanger, fængsler og fangelejre 1933-1945, afnazificeringen efter 1945 f.eks. Der er meget at gøre inden for det store område, der hedder flygtninge i Sydslesvig og Holsten. Dr. Gabriele Stübers veldokumenterede socialhistoriske værk er et spændende initiativ til indføring $i$ en barsk tids problemer. 
1959-1984. 25 Jahre Deutsches Gymnasium für Nordschleswig. Eine Festschrift 1945-1984.

Redaktion: Immo Doege og Hans Jürgen Nissen. Åbenrå 1984, 318 s., ill.

Med dette andet bind har "Deutscher Schul- und Sprachverein für Nordschleswig«, der står som udgiver, fået skrevet de første 50 år af det tyske gymnasiums historie. Første bind omhandlende perioden til 1945 er anmeldt i Sønderjyske Årbøger 1981.

Fremstillingen af denne skoles historie afspejler en vigtig side af det tyske mindretals liv med 1945 som det skæbnesvangre år, hvor mindretallets fortsatte eksistens og dets overlevelsesmuligheder var et åbent spørgsmål. I ydre henseende er dette markeret $\mathrm{i}$ to-bindsudgivelsen, idet første bind er beretningen om det "gamle« gymnasium til dets lukning i 1945, mens det andet bind beretter om fortsættelsen, »der den Zeitraum des Neubeginns nach 1945 bis heute umfasst«.

Bogen falder $\mathrm{i}$ to dele. På de første godt hundrede sider fortsætter Immo Doege den $\mathrm{i}$ første bind påbegyndte fremstilling af det tyske skolevæsens udvikling efter 1920 med speciel henblik på eksamensskolen, hvorefter de følgende 200 sider indeholder mange slags bidrag fra såvel tidligere elever og lærere som fra nuværende, der beskæftiger sig med skolens daglige liv og undervisningen under forskellige synsvinkler. Der kan her være grund til at pege på de indlæg, der belyser et for et mindretalsgymnasium centralt tema, nemlig kravet om dobbeltsprogetheden og de med dette krav forbundne udfordringer - og problemer.

Bogen afsluttes med en nyttig oversigt over lærerkræfter ved skolen siden 1959 samt over elevtal, ledsaget af en statistisk bearbejdelse.

Det af Immo Doege fremlagte arbejde om det tyske skolevæsens opbygning efter anden verdenskrig med særlig henblik på eksamensskolevæsenet er bogens kærnestykke. Heri skildres indgående den juridiske og politiske baggrund $\mathrm{i}$ dens mange facetter, til den gymnasiale undervisning blev genoptaget 1959 efter en afbrydelse på 14 år som følge af begivenhederne efter det tyske sammenbrud i maj 1945, der resulterede $\mathrm{i}$, at næsten alle tyske skoler blev lukket og den erhvervede eksamensret blev inddraget. Hjemmetyske elever, der ønskede at tage kvalificerende eksaminer var henvist til de danske gymnasier, medens det tyske mindretal søgte at opbygge et skolevæsen nedefra (1948: 4 tyske skoler, 1958: 30).

Med København-Bonnerklæringerne 1955 blev eksamensforbudet for de tysksprogede skoler ophævet og dermed var der banet vej for 
en videreudbygning af det tyske skolevæsen. Alligevel gik der endnu nogle år, inden det tyske gymnasium kom i gang, idet nogle inden for den hjemmetyske forældrekreds fandt, at oprettelsen af et tysk gymnasium påny ville kunne isolere mindretallets unge, hvorfor det var tilstrækkeligt med en mellemskoleafdeling ved de tyske skoler, medens andre var af den opfattelse, at elever efter en studentereksamen forlod Nordslesvig og senere hen var deres tilbagevenden til hjemstavnen meget usikker og endelig blev spørgsmålet, om der var et tilstrækkeligt elevgrundlag til at bære et gymnasium rejst. Den tyske skoleforening besluttede sig dog for oprettelse af et gymnasium, der efter forhandlinger til såvel dansk som tysk side startede undervisningen august 1959.

Immo Doego afstår fra nærmere at gå ind på den negative holdning, som han sporer fra dansk side over for de tyske genopbygningsforsøg. Han vil blot skildre, på hvilken måde efterkrigstidens danske lovgivning virkede. Det træder frem omkring kontroversielle spørgsmål som f.eks. beslaglæggelsen af de tyske skoler ("Zur juristischen Haltbarkeit ... kann hier nicht Stellung genommen werden « s. 20) og omkring retsopgøret ("Das sehr komplexe Problem ... muss unberücksichtigt bleiben«. S. 10) ligesom det vedrørende cirkulæret om gennemgang af de på tyske skoler benyttede læse- og lærebøger hedder: „Über die Rechtmässigkeit dieser Verfügung kann hier nichts ausgesagt werden« (S. 28).

Det skal ikke bebrejdes ham i et festskrift til det tyske gymnasium. Men der spores en mangel på den selvbesindelse, der kom til udtryk i den hjemmetyske loyalitetserklæring fra efteråret 1945, hvori en afstandtagen fra mindretallets politik under nazistisk ledelse kom til udtryk, når den modvind, som ramte mindretallet og dets skolevæsen forklares på følgende måde: „Dem allgemeinen dänischen Hang zur Kriminalisierung grösserer Teile der deutschen Volksgruppe in den ersten Nachkriegsjahren fielen somit nicht zuletzt auch die Schulen der deutschen Volksgruppe und der grössere Teil ihrer Lehrer zum Opfer« (S. 9). Det kniber altså stadig med at forstå den berettigede forbitrelse, som mindretallets adfærd og politiske kurs ikke mindst under besættelsen havde vakt i danske kredse!

Knud A. Rasmussen 
Henrik Becker-Christensen og Jørgen Witte: Fra købstad til storkommune, Aabenraa bys historie, bind 4, 1945-1970.

Skrifter udgivne af Historisk Samfund for Sønderjylland nr. 61, Aabenraa 1985,398 s., ill.

Målet med lokal- og kulturhistorie er jo i sidste instans, at det enkelte menneske skal kende sig selv lidt mere. En historiker vil i løbet af sit virksomme liv skifte mellem at fortælle ny viden for andre - og at få sat et »historisk lys « på ting i sit eget liv, som indtil da var uhistoriske, fordi »sådan var det bare《 - ikke mindst i barndommen. Da jeg i 197475 arbejdede med Aabenraas mennesker og huse mellem 1850-1920 havde jeg da også ind imellem den oplevelse, at en stemning, et indtryk pludselig fik en forklaring. De mange mærkelige efternavne i den indre bys baggårde eller i Rugkobbels nye blokke - det var jo den sydfra tilvandrede arbejderklasse fra omkring 1900. De underlige trappeopgange $\mathrm{i}$ den indre by, når jeg rendte med politisk materiale - det var jo vidnesbyrdene om den indre bys ombygning efter 1850 , hvor husene skiftede anvendelse og fik flere og flere lejemål.

Ved læsningen om Aabenraa mellem 1945 og 1970 havde jeg adskillige gange den samme oplevelse. Som tilflyttet københavnerbarn i det nye boligforeningsbyggede Rugkobbelkvarter »uden for lands lov og ret« var alt jo i 1957 lige mærkeligt og selvfølgeligt - og siden tildels glemt igen. Men med historien om Aabenraa andelsboligforenings start i 1941, og om kommunens stærke engagement $\mathrm{i}$ løsningen af den hårde bolignød efter 1945 begyndte mønstret bag Rugkobbel-kvarteret at danne sig. Den vej så sådan ud - ja, det var jo selvbyggerhusene fra begyndelsen af 1950'erne. I de blokke eller huse boede de varste rødder - nå ja, det var altså kommunens ejendomme. Osv. osv.

Også det dunkelt opfattede helhedsindtryk af byen som stillestående og fattig, men alligevel med en masse nye blokbebyggelser og rester af store projekter, får $\mathrm{i}$ det her udkomne bind sin nærmere forklaring. 1957 var i slutningen af den tid, hvor et gammelt sparsommeligt købmandsstyre havde overtaget magten igen efter nogle få hektiske år efter krigen, hvor det socialdemokratiske styre havde taget tidlig forsmag på velfærdsstaten.

$\mathrm{Og}$ endelig er der personer, som pludselig ses i et nyt lys. Som den fru Strømming, som jeg mest kendte som stresset geografilærer, der nu viser sig at have været en gæv dame, som i 1949 havde formastet sig til at klage over, at gifte kvinder overhovedet ikke stod $\mathrm{i}$ vejviseren. Det var 4 år efter, at en anden lærerinde havde klaget over, at hun fik 
lavere 25 -års gratiale end sine mandlige kolleger - og så havde man endda glemt at invitere hendes mand med til jubilæet!

I enhver nogenlunde grundig og troværdig byhistorie er der således tusind ting til fornøjelse for den pågældende bys borgere, især de, der har oplevet tiden selv. Og Aabenraa 1945-1970 er et hæderligt eksemplar af slagsen. I sammenligning med andre byhistorier, som jeg har læst i de seneste år, er for eksempel adskillige kapitler ret så underholdende skrevet - f.eks. afsnittet om byrådets arbejde "fra Fink til Camma«. Forfatterne har da også, ifølge forordet, ønsket at se på deres lille by "med en troldsplint $\mathrm{i}$ øjet«. Dertil kommer den flittige brug af lokale vittighedstegninger - men hvad ellers i Bo Bojesens fødeby?

For den udenforstående, forsker eller »menigmand ", har den traditionelle byhistoriske monografi (beskrivelse af en by) en eller to akilleshæle. Den ene er, at så mange byhistorier følger den traditionelle model med, at "så meget som muligt skal med«, og helst inddelt efter arkivgruppernes logik i kirke, skole, osv. osv. Herved bliver byhistorierne for udenforstående dels let noget kedelig, dels betyder den omfattende emneopdeling, at man har svært ved at opfatte byen som en helhed, som en by-personlighed med sit eget liv og sin egen stil. Heldigvis rådes der i Aabenraa 1945-1970 noget bod på dette ved et glimrende oversigtskapitel i starten, der sammenfatter udviklingen og bringer nogle oversigtskort. Med hensyn til emneopdelingen har forfatterne været sig bevidst, at der under alle omstændigheder er tale om et valg ("Selv om en historiker anvendte hele sit liv, ville han dog ikke kunne beskrive alle sider af en bys historie«, siger forfatterne meget fornuftigt på side 9!) - og flere af emnerne er da også valgt som specielt Aabenraa'ske, som for eksempel afsnittet om den betydelige engroshandel, om bolignøden, om trafikproblemerne og om det dansktyske. Alligevel er der forholdsvis mange gentagelser og afsnit med kun tørre facts, som kunne være undgået, hvis beskrivelsen af Aabenraa 1945-1970 i endnu højere grad var blevet "hængt op« på nogle få hovedemner, et fælles skelet, hvadenten det nu kunne have været den fysiske, den økonomisk-sociale eller den politiske sammenhæng. I afsnittet om byrådspolitikken falder f.eks. mange brikker på plads, som har været fyldigt beskrevet forinden.

Den anden akilleshæl ved en bymonografi er, at byen "står alene«, at man ikke ved, om byen er speciel, foran, bagud osv. på en række områder. I virkeligheden burde byer beskrives to og to eller tre og tre, helst sammen med helt anderledes byer. Ved en sådan sammenligning 
kunne for alvor byens særlige udviklingsprofil komme til sin ret. - Ved sammenligning med den nye industriby Esbjerg, der siden århundredeskiftet har været socialdemokratisk styret, slår det for eksempel en, hvor meget det Holger Fink'ske styre siden 1920 var kommet til at betyde for vilkårerne for småfolk i Aabenraa. Talrige sociale foranstaltninger, som vi i dag betragter som en selvfølge, kom først til Aabenraa enten $\mathrm{i}$ socialdemokratiets korte regeringstid 1946-50, eller når der på landsplan direkte blev lovgivet om det. I det perspektiv står den socialdemokratiske borgmester Buchreitz' indsats ikke - som det længe blev opfattet $\mathrm{i}$ byen - som en ren revolution, men som en indførelse af ting som skolelæge, skoletandlæge, børnemælk, kommunale jordkøb, planlægning osv., som havde eksisteret i Esbjerg siden 1914. På den baggrund fremstår borgmester Erik Jessens tid 1958-1970 som en fremsynet, progressiv periode, der endelig gjorde Aabenraa til en moderne by. Dette havde bl.a. sin baggrund $i$, at dette styre ikke var primært borgerligt, men en videreførelse af en speciel Aabenraa'sk tradition siden 1940 for en "upolitisk « midterbevægelse.

For at vende tilbage til Rugkobbel-kvarteret passer kvarterets nye boligformer: rækkehuse, småblokke, ens huse, elementhuse osv. ind i det også esbjergske og københavnske billede af den første efterkrigstids mange eksperimenter med bebyggelsestyper i modsætning til fantasiløsheden mellem 1958-1978 - tiden, som skabte Guldbjergparkens dødsenstriste betonblokke.

Og mens vi er ved det ydre miljø: byen - og arkitekt K. A. Flade får med rette ros for at have været foran med bygningsbevaringen i slutningen af 1960 'erne. Ak, ja - hvor flade kan laurbær blive i 1980'erne.

Sin særlige grænselandstone får byhistorien jo ikke mindst med det stadige dansk-tyske spørgsmål. Der lægges ikke skjul på, hvad mindretallet gjorde under krigen, og hvor svært det var at afsværge fortiden, men heller ikke Buchreitz' konsekvente aversion mod "tysken « beskrives ukritisk. Undertiden gives der en antydning af lejre også inden for tyskheden, og $\mathrm{i}$ hvert fald er det interessant at se de lokale repræsentanter for den nazismekritiske Haderslev-bevægelse fra 1943: Jebsen, Stolzenburg, v. Bergen, Raun, pastor Beuck m.fl. Her anes et pust fra 1800-årenes hæderlige storborgertyskhed, inden "tysk« også blev et politisk valg langt »til højre for midten«.

Baner Aabenraa 1945-1970 således ikke spændende nye veje i byhistorien, er det dog, som det vil fremgå af foregående, en godt dækkende, redelig og dog munter gennemgang af 25 snart spændende, snart 
yderst stilfærdige år. Den kan kun anbefales til alle Aabenraaere gamle eller nye!

Peter Dragsbo

\section{En replik}

Min bog »Udskiftningen og dens økonomiske og sociale følger i Sønderjylland ca. 1730-1830. En analyse af et udvalgt område på Nordals« (Studier, udgivet af Historisk Samfund for Sønderjylland nr. 1, Åbenrå 1984) har været anmeldt flere steder i sønderjyske medier. Hovedparten af disse anmeldelser har været kritiske. Værre er dog, at kritikerne synes at udtale sig uden først at have gjort sig bogens mål og metoder klart. De tager end ikke stilling hertil. Da det således må have skabt uklarhed i specielt sønderjyske læseres opfattelse af det centrale i bogens indhold, drister jeg mig til at komme med et par kommentarer, der samtidig tager stilling til nogle af hovedpunkterne i kritikken. De anmeldelser, jeg her tænker på, er i Flensborg Avis 20-11-1984 (F. S. Grove-Stephensen), Sønderjysk Månedskrift 1985 nr. 2, s. 51-53 (P. Kr. Iversen) og Sønderjyske Årbøger 1985, s. 211-13 (H. P. Jensen).

Målet med min undersøgelse har været at belyse udskiftningens betydning i økonomisk og social henseende. Hertil var der behov for en analyse af jordfordelingen før og specielt efter udskiftningen. Med henblik herpå har jeg forsøgt at opstille et mål for udskiftningens heldige eller uheldige gennemførelse i de enkelte landsbyer, baseret på arronderingsgrad og afstand fra bol til mark. Ud fra disse forhold har jeg søgt at vurdere udskiftningens økonomiske betydning for bolsmænd, kådnere og inderster. Midlet hertil har været skifteforretningernes oplysninger om de enkelte brugs kvæghold, udsæd og samlede aktiver og passiver, som jeg har sat i relation til udskiftningsresultatet for de enkelte landsbyer.

Den traditionelle opfattelse - som bl.a. er præget af Fr. Mager, Troels Fink og W. Prange - vurderer dyrkningsfællesskabet som en absolut hindring for økonomiske fremskridt i landbruget. Udskiftningen er for disse forskere et klart brud på den produktionsmæssige udvikling, der bliver til stor fordel for bønderne. Det er klart, at når jeg skal begrunde en ny undersøgelse af udskiftningens produktionsmæssige betydning, tager jeg udgangspunkt i de eksisterende unders $\varnothing$ gelser om emnet, finder uundersøgte felter i tidligere analyser og fors $\varnothing$ ger at anlægge en ny tilgangsvinkel. Her har jeg kunnet konstatere, at 
både Mager, Fink og Prange har fremført den traditionelle opfattelse af landbrug under dyrkningsfællesskab uden nøjere analyse heraf (f.eks. statistiske beregninger). Jeg har måtte spørge mig selv: Er det muligt - helst også statistisk - at be- eller afkræfte den traditionelle opfattelse af udskiftningens virkninger på landbrugets økonomi? Med dette mål har jeg gennemført min analyse af de økonomiske vilkår før og efter udskiftningen og er nået til et mere nuanceret billede end tidligere, hvor man mere holdt sig til sandsynlige skøn baseret på samtidige beretninger end egentlige beregninger. I almindelighed har jeg kunnet tilslutte mig den gængse opfattelse, at udskiftningen skabte en mere rationel drift og dermed en forøgelse af landbrugsproduktionen og en forbedring af de økonomiske vilkår for bondestanden. Dog har jeg måttet fremhæve, at der også under dyrkningsfællesskabet var fremgang i landbrugsproduktionen, blot ikke så stor som efter udskiftningen. Der var med andre ord tale om en gradvis produktionsfremgang i landbruget i hvert fald fra 1730, og landboreformerne - og her især udskiftningen - var et middel til endnu større forøgelse af produktionen, ikke et revolutionerende brud (således som en umiddelbar betragtning af lovgivningen lader ane rent strukturelt).

Jeg er blevet kritiseret for at have brugt ordet Sønderjylland i titlen, mens analysen kun dækker Nordals - således som det fremgår af undertitlen. Sønderjylland er medtaget $i$ hovedtitlen for at understrege, at analysen sættes ind i en primært sønderjysk sammenhæng - modsat kongerigsk - og tager hensyn til de særlige lovgivningsmæssige, politiske og jurisdiktionelle forhold, der gælder for hertugdømmet, og den litteratur, der findes om udskiftningen i området.

Hvad angår valget af undersøgelsesområde, skal det ses i sammenhæng med min målsætning, da jeg har lagt op til at belyse sammenhængen mellem udskiftning og økonomisk og social udvikling, og da opgaven skulle have et begrænset omfang, var det mest oplagt at vælge et mindre lokalområde i Sønderjylland, f.eks. et herred, for at kunne behandle det som en afgrænset helhed og komme til bunds heri, frem for at udvælge visse mindre områder, f.eks. sogne fra hele Sønderjylland, hvilket $i$ andre sammenhænge kan være en ganske fortrinlig metode. Da det samtidig ville være en fordel at vælge et område med høj opdyrkningsgrad, der ikke var præget af de tidlige udskiftninger, men hvor udskiftningen fulgte ganske kort efter 1766- og 1770-lovene, faldt valget på Nordals (Nørre herred $\div$ Helved og andre områder under Notmark sogn, hvilket jeg har argumenteret for s. 153, note 11). 
Disse forhold betød, at analysen kunne gennemføres under optimale betingelser for at isolere selve udskiftningen som forklaringsårsag til den økonomiske og sociale udvikling. Derved bliver analysen ikke repræsentativ for hele Sønderjylland - hvad jeg aldrig har hævdet. Hvilket enkeltområde ville iøvrigt være typisk for hele Sønderjylland? Skal mine undersøgelsesresultater fra Nordals sammenlignes med andre sønderjyske egne, skal de særlige jordbundsforhold og driftsformer, der er så afvekslende i hertugdømmet, selvfølgelig tages i betragtning, hvilket betyder, at en direkte sammenligning ikke er mulig. Hovedresultaterne kan dog sammenlignes, og i hvert fald kan arbejdsmetoden finde anvendelse $\mathrm{i}$ andre egne, både sønderjyske og kongerigske. Og at demonstrere en arbejdsmetode, som kunne begrunde tidligere ubegrundede antagelser, har været mit egentlige anliggende.

Mine anmeldere har fremhævet, at jeg ikke har omtalt den alsiske frugtavl. Det er nok lidt af en fejl, at jeg ikke har ladet flere bemærkninger falde herom, da den er særegen for Als. Men det skyldes dels, at den ikke omtales i nogen særlig udstrækning i det kildemateriale, jeg har benyttet, dels at frugtavl ikke spiller nogen rolle i udskiftningen eller bevirker forskel i den økonomiske udvikling før og efter. Frugten blev jo dyrket på tofter, i kålhaver og æblegårde, der i forvejen var i særdrift.

I denne sammenhæng hævdes, at jeg har udeladt biindtægter, da jeg har arbejdet med »rensede» tal fra skifteforretningerne. Det er ikke rigtigt, at jeg bevidst har forsøgt at holde frugtavlen uden for beregningerne. Derimod har jeg forsøgt at "rense« de enkelte priser for inflationen for at kunne sammenligne over tid, samtidig med at jeg har undladt at medtage ejendomsværdien under aktiver (da den kun forekommer efter udskiftningen) og skifte- og begravelsesomkostninger, rigsbankhæftelse (efter 1813) og beløb afsat til arvinger under passiverne, da de ikke har nogen driftsøkonomisk betydning som passiver. Det har derimod skatterestancer, lønninger og gæld i øvrigt. Dermed tør jeg ikke hævde, at jeg har fanget alle forhold af betydning ved vurdering af driftsøkonomien før og efter udskiftningen - som en af anmelderne siger, er der "mange usikkerhedsmomenter i gamle tal«. Men ved at bygge på en ensartet kildegruppe før og efter udskiftningen mener jeg at have et rimeligt sammenligningsgrundlag. I øvrigt havde det været ønskeligt, om anmelderne $i$ højere grad var gået ind i en debat om brugen af skifteforretninger $i$ denne sammenhæng.

Som flere af anmelderne vil også jeg håbe, at fortsatte undersøgelser 
om sønderjysk landbrugshistorie vil se dagens lys, specielt om den $\mathbf{i}$ mange henseender betydningsfulde udskiftning, som stadig i høj grad præger landskabet. Det sidste ord er ikke sagt. Kun ved fortsatte undersøgelser over udskiftningen i andre sønderjyske egne vil vi kunne nå til et mere velbegrundet syn end før på landboreformernes faktiske virkninger for landbefolkningen $\mathrm{i}$ hertugdømmet.

Per Grau Møller 


\section{Bognyt}

Festskrift til Troels Dahlerup. Arusia-Historiske Skrifter V. Århus $1985.428 \mathrm{~s}$.

Professor i nyere historie ved Århus Universitet, dr. teol. Troels Dahlerup fyldte 3. dec. 198560 år. I den anledning ønskede en række kolleger og tidligere elever at hylde ham med et festskrift og takke ham for inspirerende undervisning. Festskriftet indeholder 27 bidrag spændende fra arkivar Michael $\mathrm{H}$. Geltings overordentligt spændende artikel om biskop Helias i Ribe, en flamlænding i 1100-tallets Danmark, frem til Leo Tandrups portræt af C. $O$. Bøggild-Andersen, der døde 1967. Artiklerne henter hovedsageligt emner inden for Troels Dahlerups forskningsområder: den middelalderlige kirkeorganisation, adelshistorien og landbohistorien, men også emner inden for andre sider af den nyere historie er der blevet plads til. Af særlig interesse for årbogens læsere er 3 artikler, nemlig Henrik Fangel: Vesterbæk-en forsvundet hovedgård i Vestslesvig, Lars N. Henningsen: J. H. E. Bernstorff som patron (om forholdet til Fr. Wilh. Otte) og Andrea Boockmann: Das Wirtschaftsbuch der Abel Dorthea von Thynen. Gutswirtschaft und Herrschaftsküche in Schleswig-Holstein in der Mitte des 17. Jahrhunderts.

HHW.

\section{H. E. Sørensen: Vadehavet og vesteregnen.}

Melbyhus, 1985. 96 sider, ill.

Med dette sjette bind er H. E. Sørensens Sønderjyllands beskrivelse færdig. Beskrivelsen svarer hverken til Trap eller Gyldendals egnsbeskrivelse; det er den oplagte historiefortæller, der er $\mathrm{i}$ arbejde, vælger sit stof efter interessefelt, med de spring og sidespring, det medfører. Men H. E. Sørensen er en fornøjelig vejviser, og bag beskrivelsen må ligge en kæmpemæssig arbejdsindsats, der fortjener at blive belønnet ved, at mange anskaffer værket til den private boghylde. - Det er iøvrigt imponerende, at H. E. Sørensen har fået hvert af seks bind til at løbe ud på side 96, det må vist være, hvad man kalder planøkonomi.

Til vesteregnen hører vitterligt Tønder - og Højerområdet. Dem har H. E. Sørensen imidlertid behandlet i første bind af serien "Langs grænsen «. Til gengæld inddrager han nu Ribe, hvorved Sønderjylland unægtelig udvides noget. Hans grundlag for at gøre det »en gang en kongerisk enklave i hertugdømmet Slesvigu er forkert, men beskrivelsen stoffyldt.

Skildringen i dette bind er nøjagtig så livfuld som i de tidligere med sans for den gode historie, fremdragelse af person - og egnsstof, der har været på vej i glemmebogen, og overvejende fremragende illustrationer, der dog $\mathrm{i}$ opsætningen kan virke noget flimrende. Sagnstof inddrages fortløbende, men i forbindelse med skildringen af pastor Schmidt, Vodder, kunne H. E. Sørensen 
dog godt have udeladt Rostockmyten, der i sammenhængen fremtræder som historisk sand.

H. E. Sørensen har så mange spændende indfaldsvinkler, at hans skildring fængsler den, der kender stoffet $i$ forvejen. For turister er den enkelte bog $i$ denne serie velegnet til læsning i sommersol på en grøftekant. Overskrifter og indholdsfortegnelse gør det let at finde den enkelte lokalitet.

K.F.

Karen Andersen: Hårkullorna fra Våmhus.

Udg. ved Peter Laursen, Frederikshavn 1984.

I 1959 skrev Karen Andersen fra Frederikshavn sin første artikel om hårarbejde. Da hendes undersøgelser om disse specielle arbejder fortsatte, bragte de hende flere gange $\mathrm{i}$ berøring med Sønderjylland og flere af hendes efterfølgende artikler blev skrevet til sønderjyske tidsskrifter og årbøger, især til Sønderjysk Månedsskrift (1966 og 1981) og til Nordslesvigske Museer (1975 og 1979).

Karen Andersen arbejdede ufortrødent videre på det store undersøgelsesarbejde, også efter at hun fyldte 80 år, i det håb at kunne samle sine resultater $i$ en stor afhandling. Det lykkedes imidlertid ikke, og da hun døde i 1982, lå foruden den vældige, men ikke færdigbearbejdede materialesamling, en række kortere manuskripter. Disse er nu bearbejdede og udgivet af Peter Laursen, der gennem mange år på Bangsbomuseet på nært hold havde fulgt Karen Andersens arbejde.

Den nu foreliggende bog på 144 sider indeholder 12 afsnit samt 34 sider med detaljerede tabeller. Både i flere af afsnittene og - især - $i$ tabellerne gemmer sig mange oplysninger fra Sønderjylland. Specielt er der i tabellerne samlet materiale om handelsveje og om de svenske hårfletterskers vandringer gennem Danmark og Hertugdømmerne. I afsnittet om danske hårflettersker benyttes også en prøvebog på museet på Gottorp og et lille afsnit tager problemet om den tyske konkurrence med maskinfletninger op.

Selvom bogen ikke er blevet det store, samlede værk, som oprindelig var planlagt, og selvom store dele af det sønderjyske materiale kun er blevet ret spredt udnyttet, er der dog i bogen, der er smukt og rigt illustreret, også en del oplysninger af interesse for den sønderjyske erhvervs- og handelshistorie.

J.S.

Henrik Becker-Christensen og Preben Sørensen: Hedeby.

Kilder og tekster. Amtscentralen for undervisningsmidler i Sønderjylland. 1985. 44 sider, ill.

Indledningsvis præsenterer forfatterne i en kort artikel Hedeby og diskussionen om dens placering. Derefter følger 18 kildeudtog til belysning af navnet, kampene om Hedeby, Hedeby som handelscenter, Hedeby og kristendommen og endelig araberen Ibrahim ibn Jacubs skildring af beboerne, særlig kendt for hans vurdering af deres sanglige ydelser: »det er en brummen, som kommer af deres struber, i lighed med hundegøen, dog endnu mere dyrisk end denne«. 
Derefter følger tekstudtog under overskriften Det glemte Hedeby (Danckwerth, Erik Pontoppidan, Johannes von Schrøder) og Det genfundne Hedeby (Sophus Müller, Johannes Steenstrup, Friedr. Knorr og Herbert Jankuhn). Hæftet sluttes med en gengivelse af $\mathrm{H}$. V. Gregersens skildring i "Slesvig og Holsten indtil 1830 (1981).

Hæftet rummer et righoldigt kortmateriale og velvalgte illustrationer, som papirkvaliteten dog hindrer $\mathrm{i}$ at komme helt til deres ret.

Hæftet er fremkommet samtidig med åbningen af det fremragende museum ved Hedeby Nor. De mange historisk interesserede, der valfarter hertil, kunne have megen glæde af at sætte sig ind i stoffet ved hjælp af hæftet, der i sin sværhedsgrad ellers især må være rettet mod gymnasiets elever. Lad os håbe, at ekskursionsbevillingen vil tillade mange danske gymnasieklasser at aflægge besøg i Hedeby. Det må forventes, at museumsledelsen, såsnart den har fảet udarbejdet det tysksprogede katalog, lader det følge af en dansksproget. Selv nogenlunde tyskkyndige kan komme $\mathrm{i}$ vanskeligheder stillet over for den tekniske terminologi.

K.F.

Helle Denckert og Henrik Fangel: Aabenraa Byhistorisk Atlas.

Udgivet af Aabenraa Museum og Amtscentralen for Undervisningsmidler i Sønderjylland. Aabenraa 1985. $48 \mathrm{~s}$.

1. maj 1985 fejrede Aabenraa by sit 650 års købstadsjubilæum, og \#Aabenraa Byhistorisk Atlas« er måske den bredest favnende blandt jubilæumspublikationerne. Bogen er tænkt som et undervisningsmateriale, men kan i mindst lige så høj grad benyttes af den almindelige historisk interesserede laser.

Gennem 29 kort, prospekter og luftfotos tegnes et tværsnit af byens udvikling gennem mere end 650 år. Den ledsagende tekst forklarer letforståeligt og vidende, hvordan bybilledet og dets omgivelser har udviklet sig i samspil med de skiftende vilkår for byens trivsel. Læseren følger byen fra den spæde start på bybakken og gennem århundreder, hvor de omgivende enge og bakker dannede en uigennemtrængelig mur, indtil vore dages mere spredte bybebyggelse også har taget enge og bakketoppe $i$ besiddelse. Den lille bog giver faktisk i kort form en byhistorie fra omkring år 1000 til i dag - overkommelig for den, der ikke orker at læse de bindstærke værker. Undervejs făr læseren talrige enkeltoplysninger om veje, vandløb, gadenavne, institutioner og virksomheder osv, og der er tabeller over udviklingen i befolkningstal, skibsflåde m.v.

De enkelte stort gengivne kort og billeder kan åbne øjnene for mange spændende iagttagelser. Blot ét eksempel: På det sidste kort i bogen illustreres, hvordan matrikelskel mange steder $i$ byen fortæller om beliggenheden af vandløb, kystlinjer, byvolde og byens gamle borg - et sådant kort inspirerer til at gå på opdagelse $i$ gaderne på jagt efter fortidens endnu levende spor. Enkelte af de gengivne luftfotos er desværre så grumsede, at de næppe muliggør detailstudier. Men det er skønhedspletter i en publikation, som bør efterlignes andetsteds. 
Christian Kaatmann: Stationsbyer i Sønderjylland - Toftlund og Hjordkær. 68 sider. Ill. Institut for Grænseregionsforskning. 1985.

Statens humanistiske forskningsråd besluttede i 1980 at iværksætte et projekt om stationsbyens historie i perioden 1840-1940. Forskningsrådet fandt, at det ville være vanskeligt at inddrage Sønderjylland $i$ undersøgelsen, da forholdene her var helt anderledes end i kongeriget. Imidlertid så man gerne, at der blev foretaget en særlig undersøgelse af de sønderjyske stationsbyer. I 1984 indledtes så et samarbejde mellem Forskningsrådet og Institut for Grænseregionsforskning om stationsbyprojektet. Det første resultat af den sønderjyske undersøgelse foreligger nu. Institutet har udgivet Christian Kaatmanns lille afhandling om Toftlund og Hjordkær.

Det kan straks siges, at undersøgelsen er meget forskellig fra de hidtil udkomne bøger om stationsbyer nord for Kongeåen. Christian Kaatmanns bog er letlæselig, men nogen dybdeboring er der ikke tale om. Stationsbyprojektets oplæg til undersøgelsen er kun fulgt i beskedent omfang. Stationsbyernes topografiske udvikling samt politiske (nationale), sociale og kulturelle forhold omtales kun kort, hvor hvert enkelt område ret let kunne være et kapitel for sig. Til gengald indeholder den lille bog en række gode og morsomme illustrationer fra den beskrevne periode. Forfatteren siger $i$ forordet, at det er en foreløbig undersøgelse, og han beklager, at der kun findes meget lidt lokalhistorisk litteratur om stationsbyerne $\mathrm{i}$ Nordslesvig. Man kan så håbe på, at denne bog kan inspirere de mange lokalhistoriske foreninger til i deres årbøger at følge sagen op. I så fald har bogen udfyldt en mission.

P.A.

Logumskabet. Redaktion: Poul Svensson. Fotografier: Helge Krempin. Forlaget De unges Kunstkreds, 1985.

56 sider, ill., samt 19 helsides farveplancher.

I sin serie om sønderjysk kirkekunst har De unges Kunstkreds udsendt denne nye pragtbog. "Ønsker man en mere fyldestgørende og samtidig mere folkelig historieformidling, må billedvirkningen udnyttes fuldt ud«, hævder Poul Svensson, og det bliver den her i Krempins fornemme optagelser af skabet $i$ sin helhed og detaljer fra det, især dog i de 16 store plancher, der gengiver de 16 helgenfigurer, der dækker hver sit skabsafsnit, når lågerne lukkes. Her fremkommer med fotografiet en detailrigdom, der fæstner sig stærkt.

Mag. art. Elisabeth Kofod-Hansen beskriver i sit afsnit skabet og drøfter dets funktion. Hun rejser spørgsmålet om det oprindelig har haft sin plads på alterbordet - $\mathrm{i}$ relation til, hvad tilfældet har været $\mathrm{i}$ andre cistercienserklostre, specielt Doberan, hvor der har været et skab af nogenlunde samme karakter. Det diskuteres, om skabet snarere har tjent til opbevaring af de hellige kar end til opbevaring af relikvier.

Konservator Mikkel Scharff redegør for skiftende tiders restaureringsarbejde. Fra og med den store restaurering i kirken i $1844-45$ er skabet flyttet to gange og har været konserveret eller restaureret mindst 6 gange. Menighedens krav til opvarmning af kirken har bevirket skift i klimaforholdene, som det 
middelalderlige inventar ikke har kunnet tåle. Scharff redegør for, at der fraset lågerne næppe er meget af det oprindelige skab fra 1300-tallets begyndelse bevaret, ligesom moderne undersøgelser viser, at der er sket kraftig ændring af farvevirkningen i billederne $i$ forhold til den oprindelige. I et særligt afsnit giver Elisabeth Kofod-Hansen en introduktion til de enkelte helgener, der er afbildet, og redegør for kategorierne apostle, martyrer, bekendere og jomfruer, der dækker hver sin vandrette zone på skabslågerne. - Man vil føle sig velforberedt efter læsning af denne bog, når man næste gang stilles over for skabet - dog måske tillige berøvet nogle illusioner. - Gamle provst Schülein, der i sin tid introducerede skabet for mig, var overbevist om dets funktion som relikvieskab og fortalte, at han vidste, i hvilken kommodeskuffe $\mathrm{i}$ byen et af relikvierne var gemt. Han havde endda făet lov at låne det og viste det til en læge, der ikke ville attestere, at knoglen stammede fra det menneskelig legeme, hvorimod en dyrlæge kunne fastslå, at det mageligt kunne passe ind i fårets. Sic transit gloria sancti.

K.F.

Claudius Helmut Riegler: Emigration und Arbeitswanderung aus Schweden nach Norddeutschland 1868-1914 (Studien zur Wirtschafts- und Sozialgeschichte Schleswig-Holsteins bd. 8, Neumünster 1985).

$294 \mathrm{~s}$.

Den betydelige udvandring fra Slesvig og Holsten efter 1864 og den samtidige intensivering af landbruget skabte en følelig mangel på arbejdskraft. Fra 1890'erne fyldte polske, russiske og galiziske arbejdere de ledige pladser. I årene forinden, især fra 1868, var svenskerne den vigtigste arbejdskraftreserve. De blev hvervet i hjemlandet af agenter, hvoraf de fleste boede i Lübeck, og de fandt udbredt beskæftigelse på de større landbrug, ikke mindst i mejeridriften, og ved jernbanebyggeri samt på skibsværfterne ved Kiel.

Rieglers bog om denne svenske indvandring belyser omhyggeligt emnets mange aspekter. Der berettes særlig grundigt om forholdene i Holsten, mens eksempler fra Slesvig er spredte. Her fandt svenskerne imidlertid også flittig anvendelse - f.eks. på de større landbrug og ved bygningen af amtsbanerne. Bogen er den første samlede behandling af de svenske landarbejderes forhold. Det er ofte oprørende læsning om lidet menneskeværdige kår, om agenternes kneb og om myndighedernes behandling af de fremmede. Bogen bygger på et meget omfattende kildemateriale, og den vil kunne danne et godt udgangspunkt for en mere detaljeret beskrivelse af de specielle forhold i Slesvig.

Uffe-Skolen. Tonning. Dansk bornehave og skole 1935-1985.

Red. Erik Johansen og Uwe Stollberg. Tønning 1985, 72 sider, ill.

$I$ indeværende år holder mange danske skoler i Sydslesvig deres $\mathbf{4 0}$ års jubilæum; i 1985 kunne Uffe-Skolen i Tønning holde sit 50 års jubilæum, bl.a. markeret med denne smukke og indholdsrige lille bog. 
Midt under nazismens jerngreb blev skolen oprettet på baggrund af en forældrekreds' ønske og nogle landsmænds stærke tro på det rigtige i at opfylde det. Regerinspræsidenten i Slesvig gav sin tilladelse i modstrid med de lokale myndigheders ønske, nok under indtryk af det tyske mindretals store samtidige skolebyggeri i Nordslesvig. - Kommunegartner P. Larsen-Grøn, Holbæk og rektor H. P. Hansen, København var de ledende $i$ arbejdet nordfra. Vandrelærer Jørgen Jørgensen, Slesvig havde forberedt jordbunden med undervisning i dansk og husflidskurser. Børnenes deltagelse i Larsen-Grøns ferierejser og nogle unges ophold på danske højskoler var en anden vigtig faktor; fra 1927 fandtes en lille værdifuld dansk bogsamling i byen, i 1932 fik Slesvigsk Forening sin afdeling i byen,. I 1931 havde pastor H. F. Petersen sin første konfirmand, i 1934 døbte han ti børn. Samme år indsendte 17 forældre ansøgning om dansk skole for deres 25 børn. Den blev så taget i brug med A. Kilde Jensen som første leder den 20. oktober 1935, og måneden efter fulgte børnehaven. Altsammen træk, der belyser en national vækkelse, hvis mønster man kender andetsteds fra - også i Nordslesvig, nogle årtier tidligere.

Der er mange bidragydere til hæftets skildring af de 50 års skolevirke - men intet bidrag er ligegyldigt, og man făr tillige indsigt $i$ byens samlede forhold og udvikling. Ingen nulevende skal nævnes i denne korte omtale; men det skal fremhæves, at skoleinspektør Anders Kølvrå's indsats i tiden fra 1939-55 aftegner sig vægtigt i skildringen. Vil man have sin viden uddybet, læser man samtidig i »Barn og ung i Sydslesvig" (1986) side 370-381.

K.F.

Leif Dahl og Helge Krempin: Sophie B. Jensen. En Kunstner i grænselandet. Forlaget De unges Kunstkreds, 1985, 124 sider, ill.

Bag den såvel indholdsmæssigt som udstyrsmæssigt fornemme bog ligger et udstrakt teamwork, som ofte bag kunstkredsens arbejder. Leif Dahl takker da også i sin epilog tekstforfatterne Carsten Henrichsen og Paul Tappe, Poul Svensson som manager, og Johann Runge for finpudsning af de til tysk oversatte tekster. Mange flere har hjulpet, og så er der dog kommet en smuk helhed ud af det.

Mennesket og kunstneren træder frem, og 50 af hendes værker præsenteres smukt $i$ bogens store format $-31 \times 24 \mathrm{~cm}$ - heraf 25 sort hvide og 25 farvegengivelser. Helge Krempin demonstrerer her atter sin eminente dygtighed som fotograf, og Sopfie B. Jensens farver træder klart og dækkende frem.

Der er al mulig grund til at udsende en bog som denne. Danske kunstnere i Sydslesvig har og har haft det svært. De opfylder ikke betingelserne for at få dansk statsstøtte, og de optages ikke på de officielle lister, inden for hvilke opkøb til samlinger eller udsmykning foretages med tyske midler. Ethvert forsøg på at rokke ved dette forhold, må hilses med tilfredshed - og det formål tjener bogen også.

Bogen rummer udførlig redegørelse for Sophie B. Jensens uddannelse og studier og indgående og klar vurdering af hendes kunst - og sætter den i relation til hendes skæbne som grænselandsmenneske, om hvilken en række af hendes store værker markant vidner. Og så er mødet med Sopfie B. Jensens 
portrætter og portrætskitser, hentet ikke mindst i Flensborg, måske det, der fascinerer mest.

Bogens første sider, hvor Sophie B. Jensen beretter om sig selv og sine tanker over en periode på 50 år, vil blive stående som et kulturhistorisk dokument.

Nærværende korte omtale må kun betragtes som en appetitvækker. Bogen er takket tilskud gribende billig, og den bør nå langt ud. Og så er det bedste af det hele, at den ikke sætter slutstreg. Den af vækst spinkle og af fremtoning beskedne maler fortsætter sit arbejde og sin udvikling. - Et besøg hos hende er som et besøg i Alladins hule. Jeg har kun én indvending mod bogen: at man flere steder taler om Sophie. Det minder mig om de studentereksamensstile, hvor Karen Blixen omtales som Karen, Tove Ditlevsen som Tove. Lad dog damen beholde sit fulde navn.

K.F.

\section{Oversigt over årsskrifter og periodica}

udgivet af lokalhistoriske foreninger, museer og arkiver i Sønderjylland $1985-86$.

Ved Ib Andersen

Bov

Fra Bov Museum.

Udgivet af Historisk Forening for Visherred.

Årgang 8. 1985. Indhold: H. H. Bang: Foreningen - Nis Johnsen: Sangkor i Bov gennem 100 år - Hans Lorenzen: Min deltagelse i modstandskampen Gunnar Nielsen: Snefoged i Hokkerup - Chr. Larsen-Bjerre: Flyveplads ved Krathuse og flyskjul i Frøslev plantage - Chr. Larsen-Bjerre: En anden krigsbegivenhed - Peter Thomsen: Tiden i Kragelund under 2. verdenskrig.

Redaktør: Inger Jørgensen, Hokkerup. Skriftet kan erhverves ved henvendelse til Thorvald Larsen, Østerløkke 13, 6330 Padborg. Telf. 04671914.

\section{Broager}

Broagerland.

Udgivet af Lokalhistorisk Forening for Broagerland.

Nr. 3. 1984. Indhold: Chr. Frederiksen: Et hus i Brunsnæs - Hans Chr. Andresen: Min oldefars bryllup og stormfloden 1872 - Richard Dethlefsen: Egernsund i ældre tid - Lory Carstensen: Hyrden fra Broager, der blev blomstermaler - Peter A. Petersen: Brunsnæstjørnen - Juul Petersen: Teglværklerets historie på Broagerland og ved Nybøl Nor gennem tiden - Chr. Høy: Færgefart ved Egernsund -

Skriftet kan erhverves ved henvendelse til Ihles boghandel, Storegade 23, 6310 Broager. Telf. 04441100.

\section{Felsted}

Historisk Årbog For Felsted Sogn.

Udgivet af Historisk Forening for Felsted Sogn. 
Nr. 3. 1985. Indhold: J. H. Jensen 1896-1979 - Jacob Clausen: Verdenskrigen 1914-18 - Svend Lauesgaard: Erindringer fra tiden før og efter Genforeningen - Peter Petersen: Den danske flåde i Søgård sø - Hans Jørgen Thomsen: Sagn fra Felsted sogn - Ib Andersen: Gamle minder fra Hisselgård $\mathrm{i}$ Tumbøl - Peter Petersen: Claus Eskildsen - Ib Andersen: Landsbyen Kiding - Anders Jessen: Træk af Felsted sogns fattigvæsens historie - Peter Petersen: Historisk Forening for Felsted Sogn 1984-1985.

Redigering: Anders Jessen, Felsted, Ib Andersen, Varnæs og Peter Petersen, Ny Skovbøl. Skriftet kan erhverves ved henvendelse til Mette Lassen, Bygbjergvej 17, Felstedmark, 6200 Aabenraa. Telf. 04685119.

\section{Gråsten}

Historisk Forening for Graasten by og egn.

1985. Indhold: Verner Bruhn: Generationen imellem - Hans Munk Hansen: Teglværker i Rinkenæs sogn - J. V. Hansen: Graasten omkring 1937/38 Elsebeth Thygesen: Årets gang 1984.

Skriftet kan erhverves ved henvendelse til Poul Andersen, Munkemølle, 6300 Gråsten. Telf. 04658244.

\section{Hjordkar}

Hjordkær-heftet.

Udgivet af Hjordkær Borgerforening.

1985. Indhold: H. C. Clausen: En episode i 1943 - Christian Begh: Vore gamle veje - Peter S. Jørgensen: Før Genforeningen i 1920.

Skriftet kan erhverves ved henvendelse til Anders Eriksen, Fuglevænget 27, Hjordkær, 6230 Rødekro. Telf. 04666830.

\section{Kliplev}

Fra Kliplev sogn.

Udgivet af lokalhistorisk forening for Kliplev sogn.

1985. Indhold: Foreningen - For 50 år siden (Hejmdal) - A. Callesen: Da besæettelsen kom til Kliplev - P. M. Petersen: Tågetanker - Jes P. Nielsen: Minder fra Kliplev - H. Larsen: Kliplev frivillige brandværn - I. Hansen: En almuekvinde fortæller - Billeder fra det gamle Kliplev - Hilsen fra Søgaard Beskrivelse af Kliplev, 1864 - Kort over Kliplev, 1877 - J. Hansen: Kliplev gårde - J. K. Hansen: Et tysklandseventyr.

Skriftet kan erhverves ved henvendelse til Peter Martensen Petersen, Vestervang 3, Kliplev, 6200 Aabenraa. Telf 04687688.

\section{Lojt}

Det gamle Løjt.

Udgivet af Løjt Sogns lokalhistoriske forening.

Nr. 8. 1985. Indhold: Mads J. Lildholdt: Brevveksling - Anne Bundesen: Penneveninder på genforeningstiden - Nis Jørgensen: Udvandring til Australien - Julius Berg: Kært barn har mange navne - Petrea Schmidt: »Æ Bleendmands Gaard « i Barsmark - Hans Hansen Toft: Fladsten-dagbogen - Jacob Holdt: Anlæg i Rundemølle Dal - Sophie Berg: En løjtinger-sømands skæbne - Urban Schrøder: Dyrkjær - en fantasi - Bent Thomsen: Fra det gamle 
Barsmark - Petrea Schmidt: Skorstensindretningen - Hans Hansen Toft: Ved Spindehjul og Tælleprås - Erika Krag: Afskrift af et brev fra en sømandsenke - Petrea Schmidt: Elwine fra Dybvighovedvej - Hans Mikkelsen: Den kjedsommelige Prædikant - Jens Bruun: Orgelpulpituret i Løjt kirke - Petrea Schmidt: To sømandsbreve - Hans Joachim Spies: Fredensborgdugen fra Løjt - Petrea Schmidt: Et skolebillede - Henry Iversen: Sofie Iversen - tante Fie - Mads J. Lildholdt: Omkring afstemningstiden - Julius Berg: Lidt om vejene i Skovby - Povl Reuter Jespersen: To gamle breve - E. Juhler: Præstesønnen fra Als. Kirsten Hansen og Gunnar Kjer Hansen: For 40 år siden.

Skriftet kan erhverves ved henvendelse til Mads Lildholdt, Barsøvej 89, Lejt Kirkeby, 6200 Aabenraa. Telf. 04667383.

\section{Rodding}

Historisk årbog for Rødding kommune.

Udgivet af Rødding bibliotek.

1985. Indhold: Chr. Gundesen: Erindringer fra Rødding - P. H. Søndergaard: Flugten over grænsen - Niels H. Kragh Nielsen: Besættelsestiden 1940-45 i Rødding kommune - Lokalhistoriske arkiver, foreninger og udvalg.

Skriftet kan erhverves ved henvendelse til N. H. Kragh Nielsen, Rødding bibliotek, Kongevej 6, 6630 Rødding. Telf. 04841288.

\section{Sottrup}

Årsskriftet for Sottrup Sogn.

Udgivet af Lokalhistorisk Forening for Sottrup Sogn.

1985. Indhold: Olav J. Bonefeld: Christian Jacobsen fra Sottrupskov lodsede "La Marseillaise« ud i Lillebælt - Ingeborg Kock: Den første læge i Vester Sotttup og nogle minder - Hans Madsen: Dragonpræsten i Sottrup - Jens Lampe: Øster Sottrup skoles historie - Olav Bonefeld: Bolsmandssennen blev matematiker og russisk statsråd - Rigmor Petersen: Tanker og minder om en blomst - O. Andersen: Preussernes overgang til Als 1864 - Elisabeth Kjølseth: Pastor Nis Hanssen og træk af livet i Sottrup 1859-1866 - Olav Bonefeld: Da storken endnu var gæst i vort sogn - Kirsten Dall: 1984 - året der gik.

Skriftet kan erhverves ved henvendelse til Olav Bonefeld, V. Snogbæk 33, 6400 Sønderborg. Telf. 04467136.

\section{Varnoes}

Varnæs Birk.

Udgivet af Varnæs Birks Borgerforening.

Nr. 11. 1986. Indhold: Hans Petersen: Min livsmelodi - Thomas Kaufmann: Et eventyr under Verdenskrigen - Ib Andersen: Hejmdal 1913-14 - Peter Petersen: Varnæs sogn 1914-18 - Ib Andersen: Varnsinger som krigsdeltagere i 1864 - Urban Schrøder: Anna Jørgensdatter i Nørskov og hendes Nytårshilsen 1783 - Viggo Hviid og Ib Andersen: Volles Ras. En original fra Varnæsvig - Thomas Kaufmann: Trange tider langsomt skrider. Jul i Bovrup i gamle dage - Jes Chr. Clausen: Varnæs Birks Borgerforening 1984-85 - Skål for Varnæs.

Redigeret af Ib Andersen, Varnæs. Skriftet kan erhverves ved henvendelse til Arne Videbæk, Lærkevej 1, Varnæs, 6200 Aabenraa. Telf. 04680572. 


\section{Noter og nyt}

\section{Nekrologer}

\section{Olav Christensen 2.2.1910-6.1.1986}

Ved fhv. socialinspektør Olav Christensens død har Historisk Samfund for Sønderjylland mistet et mangeårigt bestyrelsesmedlem og sin tidligere kasserer, Haderslev by sin meget vidende lokalhistoriker og bibliograf og Sønderjylland en indsigtsfuld personalhistoriker. Tabet for familien og den store kreds af venner og bekendte kan ikke sættes på nogen formel, men er afhængigt af Olav Christensens store menneskelige kvaliteter.

Ved Olav Christensens 70-års dag, som indtraf, efter at han var blevet ramt af den sygdom, der $\mathrm{i}$ de senere år standsede hans produktivitet, skrev Peter Kr. Iversen her i Sønderjyske Årbøger en omfattende artikel, som henviste til de vigtigste områder, hvor Olav Christensen havde gjort en indsats: HaderslevSamfundet, Det unge Grænseværn, den lokalhistoriske arkivbevægelse, Historisk Samfund for Sønderjylland og den personalhistoriske forskning, for blot at nævne nogle. Denne liste er også fyldestgørende nu, 6 år efter, men helt til det sidste fulgte han, såvidt kræfterne tillod det, med $\mathrm{i}$ litteraturen indenfor sine gamle arbejdsfelter. Det var ham derfor en stor glæde, at så mange på hans 75-årsdag viste ham, at han ikke var glemt trods sygdommen.

Medens Olav Christensen $\mathrm{i}$ sine yngre år lagde de fleste kræfter i det dansk-nationale arbejde, blev de senere anvendt på den sønderjyske lokal- og personalhistorie. Her kan hans betydning næppe overvurderes. Skolet som han var $i$ at holde rede på lange talkolonner skabte han med sin systematiske sans de grundlæggende og banebrydende bibliografier over Haderslev-litteratur og slægtshistorisk litteratur med tilknytning til Sønderjylland. Hans forbillede har ingen hidtil kunne leve op til i Sønderjylland, og det tjener som en stadig inspiration. Hans egne arbejder bygger altid på et solidt kildekendskab og giver ud over de rent saglige oplysninger også det personalhistoriske »baggrundsstof «, som er så væsentligt og i perioder så forsømt. I Olav Christensens værker bliver det stående og beviser sin værdi fremover.

Når man forsøger at danne sig et overblik over Olav Christensens publikationer - en bibliografi er under udarbejdelse af sønnen Henrik Fangel forbavses man over, at der også har været tid til det organisatoriske arbejde. Men det var der, endda til tider megen tid. Timerne blev ikke talt, for arbejdet skulle gøres og blev gjort, også selvom det var rutinearbejde med f.eks. Historisk Samfunds regnskab og ekspedition.

Pionergerningen inden for den lokalhistoriske arkivbevægelse sammen med folk som Hans Brandt, Strange Nielsen og Aage Bonde er imidlertid nok den side af hans virke, som på landsbasis har sat sig de dybeste spor. Uden disse mænds indsats havde vi næppe fået den "lokalhistoriske bølge", hvis dønninger er gået over hele landet og har medført voksende anerkendelse af dette arbejde. Når Haderslev $\mathrm{i}$ dag har et byhistorisk arkiv med en videnskabeligt uddannet leder, skyldes det ikke blot, at Olav Christensen i sin tid fik oprettet det 
Olav Christensen foto: (Historiske Samlinger)

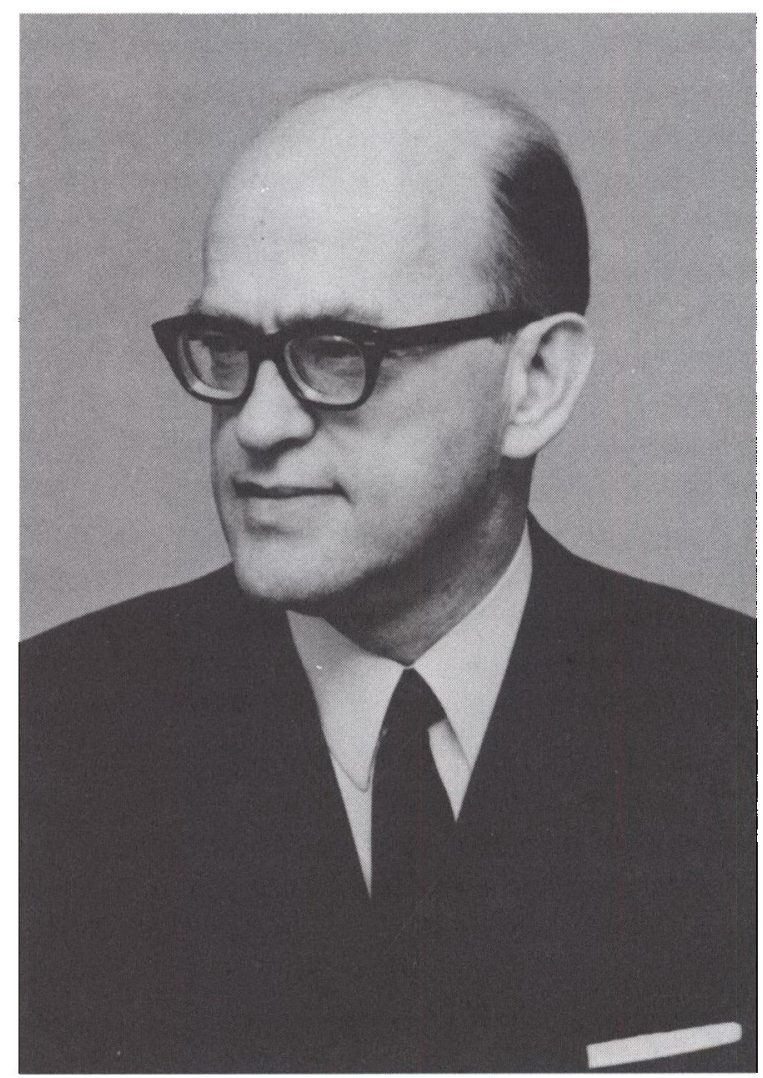

byhistoriske arkiv i Haderslev som et af landets første, men også i høj grad det opfølgende organisatoriske arbejde på landsbasis.

Man må tro, han ville have glædet sig over at opleve det.

Hans H. Worsøe

\section{Peter Clausen, 24.10.1900-2.9.1985}

Igen er en af Historisk Samfunds gamle veltjente tillidsmænd gået bort. Skoleinspektør Peter Clausen, den første formand for Åbenrå amtskreds, døde den 2. september $1985 \mathrm{i}$ en alder af knap 85 år. Han var født den 24. oktober 1900 i Begyndt ved Hostrupskov, Ensted sogn som søn af landmand Peter Clausen og hustru Cathrine, f. Sørensen. Han var således netop gammel nok til at kunne komme med i 1 . verdenskrig, men slap dog herfra uden men. Efter hjemsendelsen besluttede han at gå bogens vej, at blive lærer, idet der ved den tilstundende genforening måtte blive brug for mange danskuddannede 


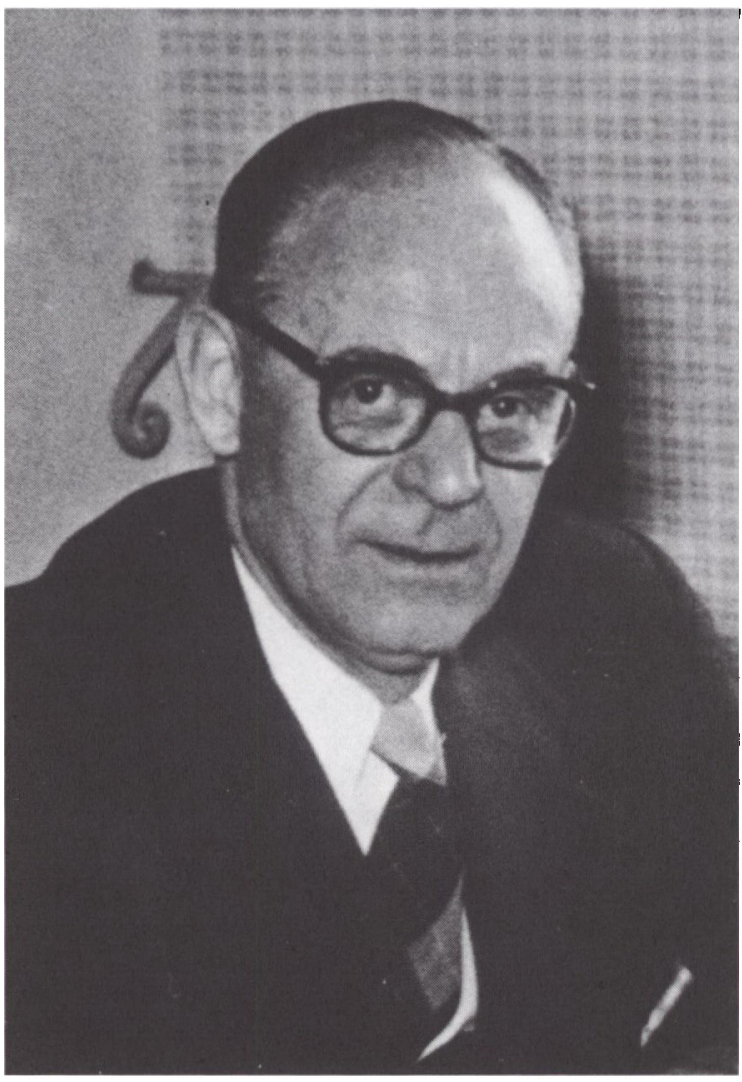

Peter Clausen

foto: (Historiske

Samlinger)

lærere, og han var indstillet på at gøre en indsats i genforeningsprocessen. Han kom på Haderslev Statsseminarium, hvorfra han dimitteredes 1922, og samme år bestod han en særskilt fagprøve i tysk. Vinteren 1922-23 var han lærer på den nyoprettede efterskole i Rens og fik derefter fra 1. april 1923 ansættelse som andenlærer i Bolderslev, Bjolderup sogn.

I 1927 indgik han ægteskab med Mette Marie Thomsen og forfremmedes 1. januar 1928 til førstelærer ved Borg skole i Brede sogn, hvorfra han dog allerede 1. september 1929 med varme anbefalinger fra tidligere stillinger kom til det i national henseende mere udsatte Hostrup sogn i Slogs herred. Her afløste han i Jejsing den navnkundige personal- og lokalhistoriker Chr. Maibøll som førstelærer. Det var således en ganske almindelig karriere for en ung landsbylærer, P. Clausen havde gennemgået indtil da. Men derefter søgte han 1936 til Sønderborg, hvor han blev viceskoleinspektør ved den kommunale Sct. Jørgensskole. Som tyskkyndig blev den erfarne skolemand efter besættelsen af flygtningeadministrationen ansat til at medvirke ved opbygningen af skolevæsenet for børnene i de tyske flygtningelejre og var bl.a. med til at sørge for, 
at gymnasiaster blandt flygtningene blev ført op til studentereksamen $i$ Vingsted ved Vejle. Efter at være vendt tilbage til Sønderbog blev han kort efter i 1947 udnævnt til skoleinspektør ved den som selvstændig skole midlertidig fungerende Skolevejs skole i Åbenrå, og han fik her den betydningsfulde opgave at forberede udflytningen til den nye Rugkobbelskole i 1953 med en lærerstab, hvori der var mange unge uden den store pædagogiske erfaring. Her på denne nye skole kom hans hovedindsats som skolemand, som administrator og pædagog til at ligge. Han fik kort sagt i løbet af kort tid skolen til at virke, og han kunne med god samvittighed og i forvisningen om at have gjort et solidt stykke arbejde trække sig tilbage som pensionist ved udgangen af oktober 1967.

Også udadtil kaldtes der på hans rige evner. Fra ungdommen var han interesseret i nationalt og kulturelt arbejde. I Bolderslevårene var han således meget aktiv i ungdomsarbejdet og blev formand for ungdomsforeningen. I Ábenrå blev han allerede 1949 indvalgt i bestyrelsen for fadderskabsforeningen for Tønning og var foreningens formand 1955-64. Endvidere var han kredsformand i Foreningen Norden 1953-56. Det var kendt, at P. Clausen havde historiske interesser, og at han havde en sjælden evne til at fange sine elevers interesse i dette fag. Det var derfor helt naturligt, at Historisk Samfund for Sønderjylland's styrelse i 1955 , da den ny struktur skulle føres ud i livet, henvendte sig til ham med anmodning om at medvirke ved oprettelsen og konstitueringen af Åbenrå amtskreds. Han blev indvalgt i styrelsen 1955 og i løbet af vinteren og foråret 1956 gennemførtes derefter under hans ledelse dette organisatoriske arbejde. Han blev Åbenråkredsens første formand og udførte her et forbilledligt arbejde i de første vanskelige år indtil 1958, da han af arbejdsmæssige grunde måtte trække sig tilbage. Historisk Samfund er Peter Clausen stor tak skyldig for, at han ville være med i dette organisatoriske arbejde.

Peter Kr. Iversen

\section{Chr. Stenz, 14.11.1909-29.4.1986}

Det er ulige mere interessant at skrive hyldestartikler ved runde mærkedage end at skulle skrive nekrologer over gamle venner og medarbejdere. $\mathrm{Nu}$ er også Chr. Stenz og dermed igen een af den kreds af yngre, som fra midten af 50 'erne var med i omstruktureringen af Historisk Samfund og arbejdet i forbindelse hermed gået bort. Johan Hvidtfeldt, Hans Neumann og Olav Christensen har vi måttet tage afsked med og af mine nære medarbejdere fra den gang er nu kun Knud Fanø og Troels Fink tilbage. Det er imidlertid glædeligt at se, at der nu igen er en kreds af unge og yngre, som er villige til at ofre kræfter på foreningens fortsatte trivsel.

Det stod nappe skrevet i stjernerne, da Niels Chr. Stenz, som hans fulde navn var, den 14. november 1909 så dages lys på en gård i Kondrup lidt nord for Randers, at han skulle komme til at udføre sin livsgerning i Sønderjylland, både syd og nord for grænsen. Han fik sin uddannelse som landmand hjemme og ude i gode lærepladser og kom derefter vinteren 1929-30 på Askov Højskole, hvor han opmuntredes til at læse videre. Han kom på Tønder Seminarium, 
hvor han for første gang stiftede bekendtskab med den særlige grænselandsstemning, og hvor han oplevede mindretallets nazificering. Og hos sin onkel Peter Petersen på Røj, den senere konservative folketingsmand, fik han lejlighed til at træffe sammen med mange af vesteregnens kendte personligheder, hvilket var med til at præge hans politiske ståsted. På og uden for seminariet var det vel dog Claus Eskildsen, som især kom til at påvirke ham. Hans interesse for danskhedens kår i Sydslesvig blev vakt, og efter lærereksamen 1935 og et års vikariat $i$ Vejstrup ved Skamlingsbanken søgte og fik han 1936 ansættelse ved den nyoprettede danske privatskole i Ladelund i Kær herred lige syd for grænsen. Her stiftede han hjem, idet han den 2. oktober 1938 holdt bryllup med sin et par ár yngre studiefæelle Ingeborg Nielsen.

Under krigen så han sig imidlertid nødsaget til sammen med sin familie at søge stilling nordpå, og han virkede da indtil 1945 som førstelærer i Nørre Hostrup. Han var her aktiv inden for modstandsbevægelsen, men benyttede også tiden til i 1944 at tage faglærereksamen i historie. I det hele taget søgte han bestandig ved kurser af forskellig art at dygtiggøre sig.

I 1945 tog han igen syd på, hvor han nu blev lærer i en barak i Vesby, Medelby sogn, medens hans hustru holdt skole i et privathjems storstue i selve Medelby. Det var under yderst spartanske forhold, familien her måtte arbejde og bo. Det er derfor også så meget mere beundringsværdigt, at der blev tid og kræfter til at arbejde med en stor undersøgelse om sprogforholdene i Mellemslesvig, hvis resultat publiceredes i Sønderjyske Årbøger 1947. Undersøgelsen om "Det danske Sprogs Stilling i Mellemslesvig i 1946« er en slags videreførelse af den tyske hjemstavnsforsker Paul Selks undersøgelse i 1930'erne om sprogforholdene i området. Stenz benyttede samme fremgangsmåde som Selk, idet han indsamlede oplysninger både om forældrenes indbyrdes talesprog, deres sprog med børnene og om antallet af rensprogede familier. Og samtidig undersøgtes forholdene inden for de gamle indfedte slagters talesprog. I et stort tabellarisk materiale belyser han udviklingen i de 10 år, der var gået siden Selks undersøgelser, og som det var at vente, var det danske sprog i de fleste sogne i tilbagegang. Afhandlingens kvalitet belyses bedst ved, at den af Dansk Historisk Fællesforening blev tilkendt prisen for den bedste afhandling i samtlige danske årboger 1947. I begrundelsen for tildelingen siges, at afhandlingen overalt er saglig og objektiv, at det store stof ikke har overvældet forfatteren og at whans fremstilling er klar og overskuelig og nu og da oplives af de små konkrete træk, der bedre end lange forklaringer fortæller om de forvirrede sproglige forhold i grænselandet«. Men med denne afhandling, der må betegnes som Chr. Stenz' mest betydningsfulde i videnskabelig henseende, var hans interesse for sprogudviklingen i Mellemslesvig ikke slut. Han fulgte stadig udviklingen nøje og udmøntede sin viden $\mathrm{i}$ afhandlinger i Sprogforeningens Årsberetning 1955/56 og 1971/72, i en længere redegørelse i Grænseforeningens Årbog 1977 samt i en række mindre artikler.

Tiden i Vesby var blevet godt udnyttet, men de primitive og små forhold her kunne i længden ikke tilfredsstille det unge, energiske lærerpars ambitioner om også at skabe sig en mere udfordrende pædagogisk karriere. De landlige forhold i Medelby sogn omskiftedes derfor 1949 med stillinger i Flensborg, han som lærer ved Chr. Paulsenskolen, hvor han allerede 1951 blev viceinspektør, medens Ingeborg fik ansættelse ved Gustav Johannsenskolen. Interesseret og 
Christian Stenz

foto: (Historiske

Samlinger)

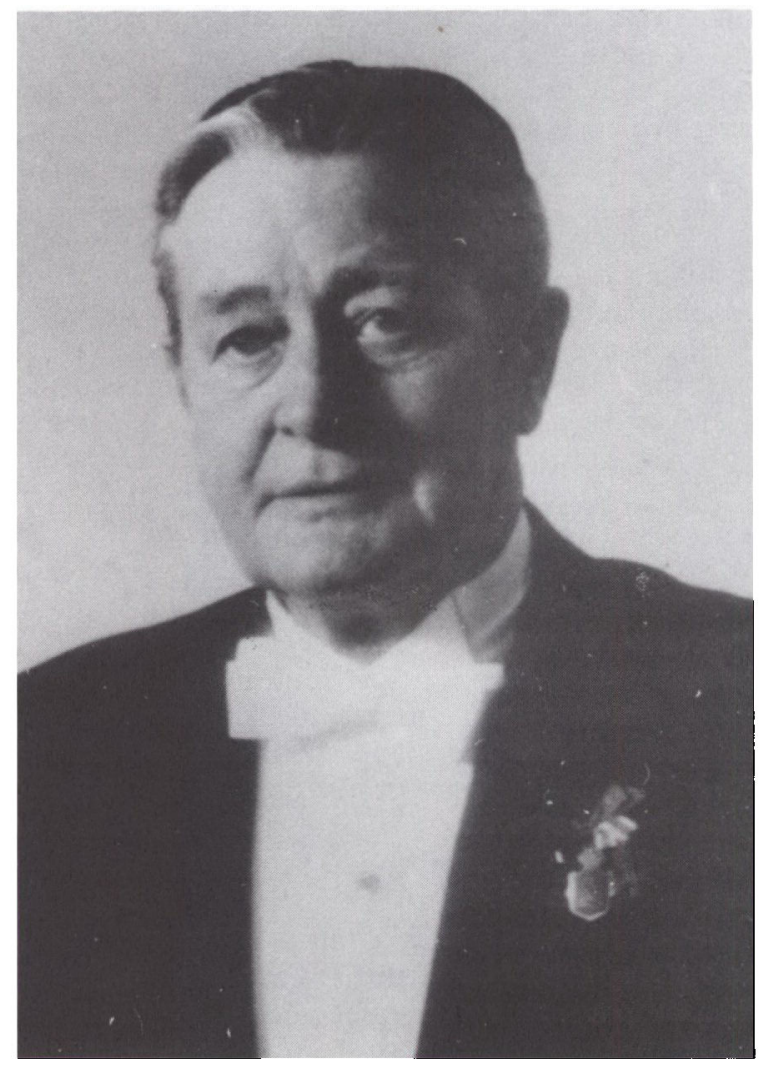

engageret $i$ organisatorisk arbejde var han 1949-52 formand for den danske lærerforening i Flensborg.

$\mathrm{Da}$ der fra forskellig side inden for Historisk Samfunds medlemskreds var blevet udtalt ønske om, at der blev bragt mere sydslesvigsk stof i Sønderjysk Månedsskrift, var det naturligt, at tanken faldt på at rette henvendelse til Chr. Stenz om at tiltræde redaktionen af tidsskriftet. Han tiltrådte da her 1949, og det følgende år blev han indvalgt i foreningens styrelse. Fra 1957 påtog han sig sekretærarbejdet og udførte her indtil 1966 en ganske særlig indsats ved tilrettelægningen af egnsvandringerne. Som næstformand fra 1966 fortsatte han endnu en årrakke dette specielle arbejde. Af redaktionsudvalget for Sønderjysk Månedsskrift var han medlem til 1979, altså ialt 30 år, og har vel her gennem årene selv leveret omkring 60 artikler, større eller mindre. Især helligede han sig kommenteringen af valgene syd og nord for grænsen og hans statistiske undersøgelser og beregninger i forbindelse hermed vil have blivende værdi.

Da undertegnede efteråret 1980 trak sig tilbage som formand, overtog Chr. 
Stenz som næstformand ledelsen af foreningen og gjorde dette på udmærket måde, indtil der i maj 1981 kunne vælges en ny formand. Samtidig udtrådte han af styrelsen og blev på årsmødet i Løgumkloster udnæunt til foreningens æresmedlem efter 31 års meget aktiv og værdsat medvirken $i$ ledelsen.

Chr. Stenz' organisatoriske interesser fandt anvendelse på mange områder. Efter at han i 1957 sammen med sin hustru havde fået ansættelse ved Rugkobbelskolen i Åbenrå, hvor han også blev viceinspektør og fungerede som sådan indtil sin pensionering 1978, deltog han aktivt i politisk arbejde. Han var ved nogle folketingsvalg fra 1964 konservativ kandidat i Tønder og Løgumklosterkredsene, og 1970 indvalgtes han som konservativt medlem af Sønderjyllands amtsråd, hvor han især lagde sine kræfter i arbejdet inden for K-U-udvalget. Han var her medvirkende til, at Sønderjysk Månedsskrift kunne bringe afsnit af Museumsårbogen i sit decemberhæfte, hvorved disse blev kendt i en større kreds. En kort tid var han tillige medlem af det sønderjyske amtsprogramråd for radioen. En overgang var han formand for Åbenrå-kredsens konservative vælgerforening og af sit parti var han udpeget til medlem af bestyrelsen for Dansk Kultursamfund. Indtil sygdom lagde hindring i vejen herfor, ledede han arbejdet inden for Grænseegnens Arbejdsudvalg.

Men også inden for sine fagfællers kreds gjorde han en betydningsfuld indsats, idet han var stiftende medlem af Dansk Historielærerforening og var foreningens første formand. Også som lærebogsforfatter har han gjort sig fortjent, idet han skrev en lille Sønderjyllands Historie beregnet for de ældre årgange $\mathrm{i}$ folkeskolen.

Af hans litterære virksomhed i øvrigt kan nævnes, at han medvirkede som redaktør ved Bov Sogns Historie, og at han gennem årene har skrevet utalte avisartikler. Sidst men ikke mindst skal dog hans livfulde erindringer nævnes, som udsendtes 1982 i Historisk Samfunds serie Sønderjyske Levnedsløb under titlen Dansk Lærer i Grænselandet. Her får man et glimrende billede af Stenz som fortæller, og det er skade, at han, før sygdom ramte ham, kun nåede at få skildringen ført frem til 1949.

Chr. Stenz var en flittig mand, der som engageret havemand kunne mere end hyppe sine egne kartofler. Han kunne overkomme meget, og han har gjort en indsats inden for Historisk Samfund, som vil blive mindet i taknemmelighed.

Peter Kr. Iversen

\section{Landsarkivet for de sønderjyske landsdele, 1985}

Medens antallet af besøgende på landsarkivets læsesal for første gang i mange år ikke udviste stigning, men synes at have stabiliseret sig på omkring 4000 (1985: 4211, 1984: 4299) har arbejdet med hjemkaldelse af embeders og offentlige myndigheders arkiver atter $\mathrm{i}$ det forløbne år bevirket en kraftig stigning i afleveringerne (380m i 1985 imod $153 \mathrm{~m}$ i 1984). Blandt de store afleveringer er der grund til at nævne Tønder kommune 1864-1940 og sammenlægningskommunerne frem til 1970. Desværre er der foretaget store kassationer i materialet fra den preussiske forvaltnings tid, men ikke desto mindre er der tale om en historisk set meget værdifuld aflevering. Andre store afleveringer 


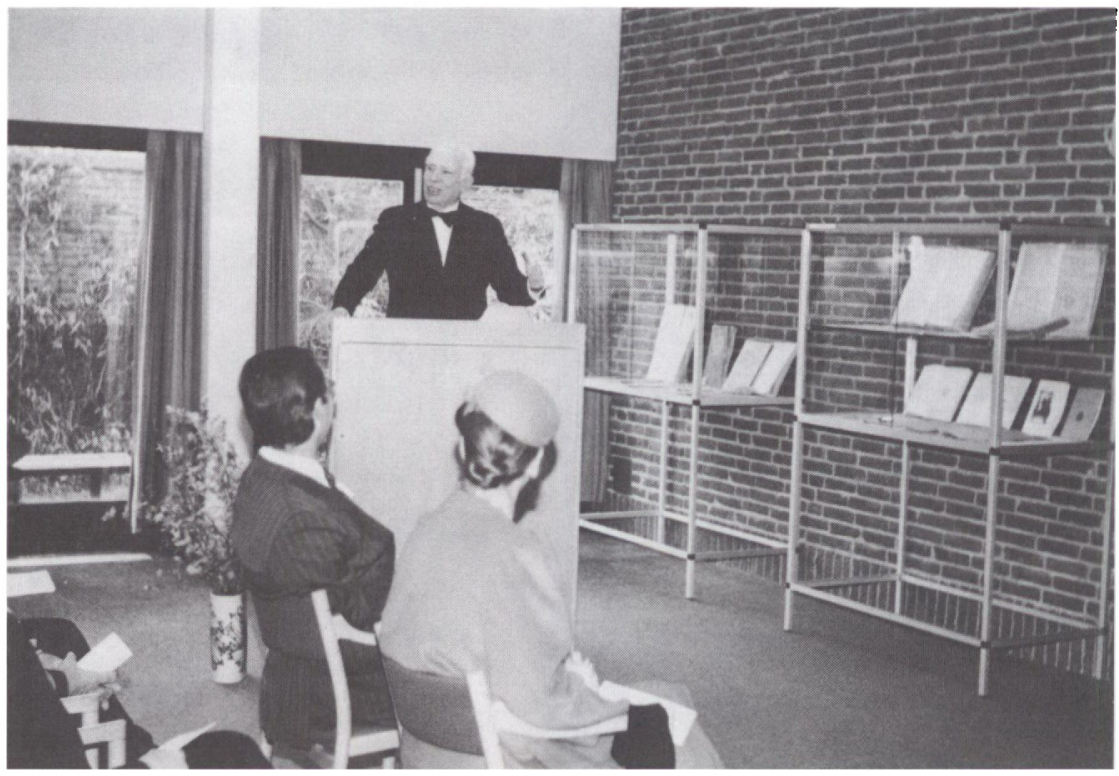

Troels Fink på talerstolen ved åbningen af jubilaumsudstillingen (Historiske Samlinger)

er modtaget fra dommerembederne i Rødding, Toftlund, Gråsten, Sønderborg, Løgumkloster og Tønder. Med sidstnævnte fulgte adskillige meter familieretlige sager fra tiden før 1920. Endelig er Haderslev Seminariums arkiv 18641920 modtaget i 1985 .

Selvom landsdelen er ved at være dækket med lokalhistoriske arkiver, som landsarkivet har et udmærket samarbejde med, afleveres der stadig en del privatarkiver og foreningsarkiver til landsarkivet, således at den herværende store og betydningsfulde samling lobende suppleres. Blandt de afleverede foreningsarkiver kan nævnes så forskelligartede ting som Aabenraa amts sognerådsforening, H. P. Hanssens Mindefonds arkiv 1971-80, De danske børneinstitutioner i Aabenraa, Sønderjyllands Symfoniorkester, Gånsager Brugsforening, Kegleklubben af 1864 og Kirkeligt Samfund for Haderslev foruden en mængde afleveringer af enkelte bind og pakker.

De $\mathrm{i}$ sidste årsberetning nævnte ordningsarbejder $\mathrm{i}$ toldarkiverne er blevet afsluttet og manuskriptet til en samlet registratur over de sønderjyske toldarkiver 1920-1969 samt Grænsegendarmerikorpset er i december 1985 indleveret til trykning i Rigsarkivet og vil forhåbentlig foreligge færdigtrykt, når denne beretning læses. Den ledige stilling ved landsarkivets værksted er besat med konservator Martin Degn Pedersen, således at værkstedet atter kan fungere med konservering, indbinding og oplæring af nye elever. Arkivar Lars $\mathrm{N}$. Henningsen er 1. september vendt tilbage fra 2 års orlov ved Studieafdelingen i Flensborg. Arkivets medarbejdere har også i 1985 i vid udstrækning deltaget i det historiske organisations- og formidlingsarbejde bl.a. med afholdelse af 


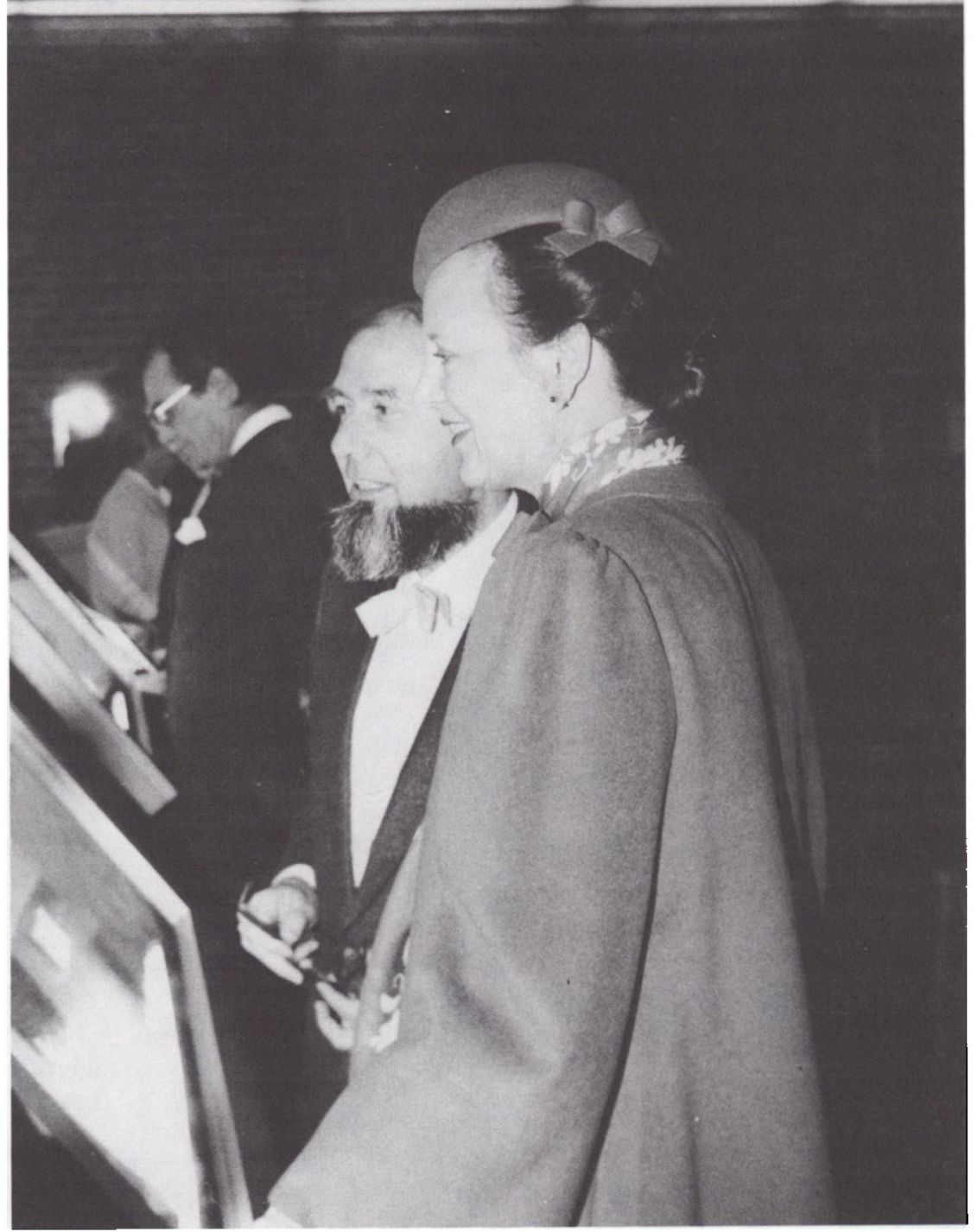


foredrag, udgivelse af publikationer og kursusledelse både på landsarkivet og udenfor dette.

Et af de foretagender, som har hjemme på landsarkivet, Historiske Samlinger for Sønderjylland, har i 1985 med ansættelsen af lektor Henrik Fangel som leder og lokalhistorisk konsulent fået karakter af en egentlig institution og har samtidig skiftet navn til Institut for sønderjysk Lokalhistorie. 25-året for samlingernes oprettelse blev den 23. november fejret på landsarkivet med reception og billedudstilling. Iøvrigt henvises til instituttets egen beretning.

Den enkeltbegivenhed, som mere end nogen anden prægede arbejdet på landsarkivet i det forløbne år, var Aabenraa bys 650-års jubilæum, eller rettere sagt 650-årsdagen for udstedelsen af Aabenraa bys skrå Phillippi-Jacobi dag, 1. maj 1335. Da skråen opbevares på landsarkivet som et af dettes klenodier, var det naturligt, at landsarkivet og dets medarbejdere aktivt deltog $i$ byjubilæet. Borgmester Camma Larsen-Ledet havde da også tildelt arkivet en væsentlig rolle både ved forberedelserne og ved selve jubilæets festligholdelse, som strakte sig fra jubilæumsdagen til langt hen på sommeren. I anledning af jubilæet besøgte Hendes Majestæt dronningen og Hans Kongelige Højhed prinsen 1. maj Aabenraa, og ved besøgets start på rådhuset om morgenen blev skråen præsenteret af landsarkivaren. Derefter blev den i hast transporteret tilbage til landsarkivet, hvor den dannede det naturlige midtpunkt i udstillingen "Arkivalier fortæller Aabenraa historie«, som i overværelse af HM dronningen med folge sidst på formiddagen blev åbnet af professor dr.phil. Troels Fink. Til denne udstilling, hvortil landsarkivet havde udarbejdet et lille katalog, havde lektor Immo Doege bidraget med materiale vedr. mindretallet og museumspædagog Helle Denckert sammen med lektor Henrik Fangel med materiale vedr. det nyudgivne byhistoriske atlas. Efter jubilæumsdagen blev udstillingen holdt åben for publikum, således at den også kunne beses i forbindelse med de to byhistoriske foredrag som Aabenraa amtskreds under Historisk Samfund for Sønderjylland arrangerede på landsarkivet om efteråret. Udstillingen og jubilæumsarrangementerne i det hele taget bevirkede, at en række skoler og enkeltpersoner aflagde besøg på landsarkivet i jubilæumssæsonen og har således lokalt været med til at udbrede kendskabet til landsarkivet og dets samlinger.

Blandt årets øvrige besøg er der særlig grund til at nævne, at Dansk Arkivselskab $\mathrm{i}$ forbindelse med et kursus på Hotel Hvide Hus den 22. november med 60 deltagere aflagde besøg på landsarkivet, samt at styringsgruppen for de Nordiske Forskningskurser ligeledes i november afholdt møde på landsarkivet, ved hvilken lejlighed rigsarkivar dr. phil. Vagn Dybdahl fortalte om Sønderjyllands historie.

Når man ser tilbage på året 1985, må man konstatere, at det har været et begivenhedsrigt år, og at landsarkivets samlinger har modtaget vigtige og omfattende nyerhvervelser. Pladsproblemer synes der dog ikke foreløbig at være udsigt til, men det er med stigende bekymring, at man under de nuværende økonomiske vilkår for statsinstitutioner må konstatere, at landsarkivets nye bygning efterhånden stiller stadigt voksende krav om vedligeholdelse.

Hans H. Worsøe 


\section{Institut for sonderjysk lokalhistorie (Historiske Samlinger)}

Styrelsen for Historiske Samlinger for Sønderjylland besluttede på sit møde den 22. november 1985, at institutionen skulle skifte navn til Institut for sønderjysk lokalhistorie. Baggrunden for dette navneskifte var, at Historiske Samlinger fra 1 . august med ansættelse af en fuldtidsbeskæftiget leder, der samtidig fungerer som lokalhistorisk konsulent for Sønderjylland, har ændret karakter. Fra at være en samling, hvis formål udelukkende var at indsamle billeder, bånd, film, traditionsstof, sang- og salmebøger m.m., har institutionen nu også fået et bredere sigte, nemlig at vejlede og rådgive lokalhistoriske foreninger og arkiver i Sønderjylland i deres virksomhed. Oprettelsen af sådanne amtskonsulentstillinger har længe været et stærkt ønske hos de lokalhistoriske arkivers organisationer, og Sønderjyllands amt er takket være en kraftig forhøjelse af amtets tilskud til Historiske Samlinger det første sted i landet, hvor en sådan konsulent er tiltrådt.

Der findes i Sønderjyllands amt ca. 70 lokalhistoriske arkiver, foreninger, grupper og udvalg, hvoraf langt de fleste foretager indsamling af arkivalier og billeder. Disse arkiver er især oprettet i 1970'erne og 1980'erne, og en del af dem er organiseret i sammenslutningen Lokalhistoriske arkiver og samlinger i Sønderjylland (LASS), der er en amtskreds under Sammenslutningen af Lokalhistoriske Arkiver (SLA).

Arkiverne i Sønderjylland er organiseret på forskellig vis. Nogle er kommunale og drives $\mathrm{i}$ tilknytning til et bibliotek, andre er foreningsdrevne, og $\mathrm{i}$ nogle tilfælde er der tale om, at et mindre udvalg står for indsamlingen af arkivalier. Kun enkelte steder er der fast, lønnet personale på deltid. I langt de fleste tilfælde er det frivilligt og ulønnet personale, der står for indsamling, registrering og formidling af materialet.

Behovet for rådgivning og vejledning viste sig at være til stede, og der blev hurtigt bud efter den lokalhistoriske konsulent. Der har været henvendelser vedrørende vejledning i registrering af så vel arkivalier som billeder, ligesom konsulenten har medvirket ved stiftelse af nye lokalhistoriske foreninger. I forbindelse med konsulentens arbejde er der aflagt besøg i en række arkiver, hvorved der er knyttet en række gode kontakter.

Konsulentvirksomheden er sket i samarbejde med LASS og Historisk Samfund for Sønderjylland. Konsulenten havde således lejlighed til at præsentere sig for de lokalhistoriske foreninger ved aftenmøder i Augustenborg og Kliplev, arrangeret af Historisk Samfund for Senderjylland.

De første fem måneder må opfattes som en del af den indkøringsfase, der skal til for at få dette nye arbejdsområde til at fungere.

Disse første måneder lover imidlertid godt for det fortsatte arbejde.

\section{Historiske Samlinger}

De Historiske Samlinger udgør stadig en del af institutionens arbejdsområde og derfor bruges betegnelsen Historiske Samlinger stadig om denne afdeling af instituttet.

Billedsamlingen har i løbet af 1985 haft en tilvækst på ca. 1800 billeder samt otte scrapbøger og fire fotoalbum. Blandt afleveringerne skal især nævnes en stor samling billeder vedrørende højskoleforstander Hans Lunds liv og 
virke, en vardifuld samling billeder, der illustrerer Aabenraa elforsynings virksomhed helt tilbage fra 1940 'erne samt en stor samling af nødpengesedler fra 1919-20. Det er vort håb at få denne samling af nødpengesedler suppleret, således at det bliver muligt alsidigt og bredt at dokumentere også denne side af landsdelens kulturhistorie.

Samlingernes negativsamling er blevet forøget ganske betydeligt i 1985 . Fotograf L. v. Münchow, Aabenraa, har således afleveret hele sin meget store negativsamling, hovedsagelig på film, og især omfattende portrætfotos. Fru Marie Kuhrts børn i Gråsten har deponeret deres bedstefar C. C. Biehls store glasnegativsamling.

C. C. Biehl var postkortfabrikant og langt de fleste af glasnegativerne er forlæg for hans postkort. Negativerne, der er af særdeles god kvalitet, er især optaget $\mathrm{i}$ tiden fra omkring århundredskiftet og frem til 1. verdenskrig og omfatter ialt 2-3000 stk. Arbejdet med identifikation og ordning af negativerne er indledt.

I det fotografiske atelier er der af Jens Ravn Jensen fremstillet 1199 billeder. Ialt er udlånt 470 billeder i kopi, heraf 111 til Aabenraa bys historie bind 4, der omfatter tiden 1945-70. Mange af kopierne er benyttet af andre institutioner på udstillinger eller i publikationer. Blandt de flittigste benyttere af samlingerne er fuldmægtig Sv. A. Faaborg, Aabenraa, men også mange andre har foretaget besøg og gennemset et betydeligt antal billeder. Antallet af udlånte billeder dækker således over en omfattende brug af samlingerne.

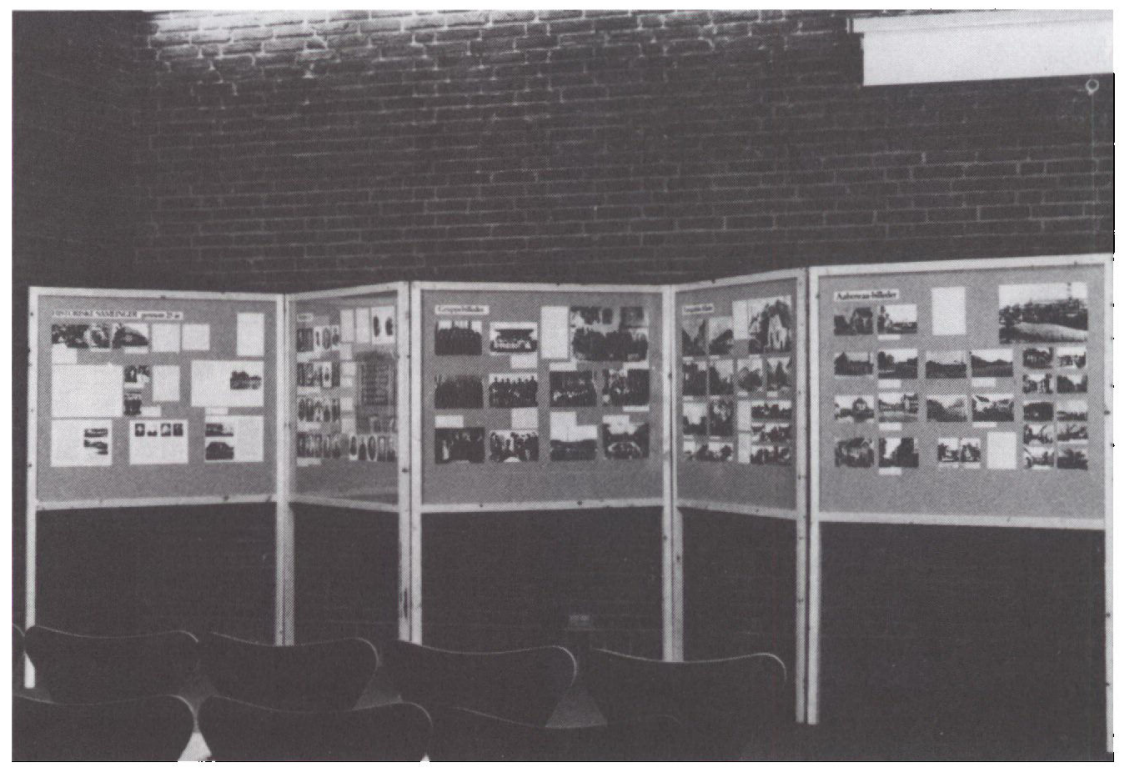

Fra jubilaumsudstillingen nov.-dec. 1985, hvor instituttets nye udstillingsudstyr blev taget i brug. Udstillingen viste eksempler på de typer af billeder, som Historiske Samlinger har indsamlet igennem 25 ar. Pd billedet ses halvdelen af udstillingen. 


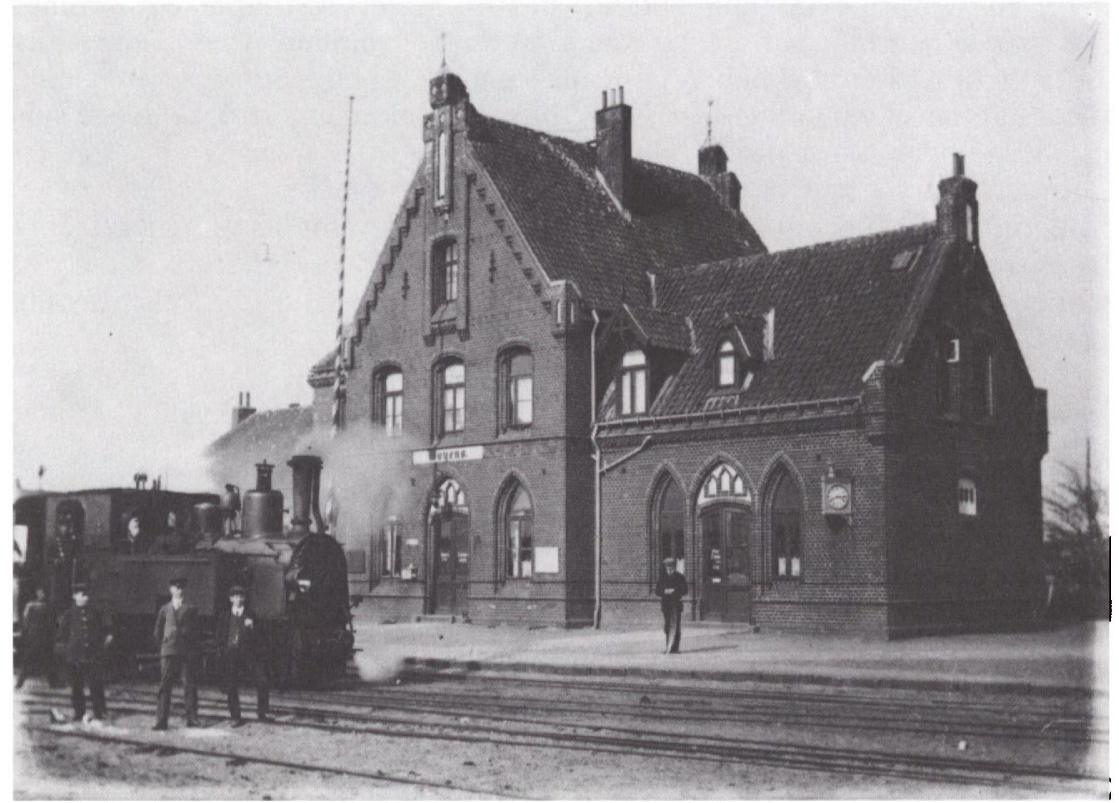

Med postkortfabrikant C.C. Biehls store glasnegativsamling har Historiske Samlinger fäet en pragtfuld samling billeder $i$ hande, der dakker hele Nordslesvig $i$ perioden fra ca. 1900 til 1940. Her ses et eksempel fra samlingen: Smabanetog $i$ Vojens $i$ begyndelsen af drhundredet.

Fruerne Inge Skifter Andersen og Birthe Wive har stået for ekspedition af de mange billeder til gennemsyn og for registrering iøvrigt.

Båndsamlingen er forøget med 22 bånd, alle overspillet af Jens Ravn Jensen, og samlingen af sangbøger er forøget med fem sangbøger. Ved hjælp af en bevilling fra Lauritz og Augusta Dahls mindelegat er der indkøbt en stor Revox båndoptager, således at båndsamlingens udstyr hermed er helt up-todate.

Historiske Samlinger kunne i 1985 fejre 25-året for samlingernes beståen. Dette jubilæum blev markeret med en udstilling og et arrangement for en bred kreds af indbudte gaster den 23. november $i$ Landsarkivets foredrags- og udstillingssal. På udstillingen vistes for første gang det udstillingsudstyr, som instituttet bl.a. med støtte fra Sydbanks Fond har anskaffet, og som det er tanken, at også de lokalhistoriske arkiver og foreninger kan gøre brug af. På ti store plancher vistes eksempler på de typer af billeder, som er indsamlet $\mathrm{i}$ årenes løb, dels $\mathrm{i}$ form af originaler, dels $\mathrm{i}$ form af affotograferinger. På et bånd var samlet klip fra Historiske Samlingers store båndsamling, klip der samtidig skulle give glimt af Sønderjyllands historie fra ca. $1914 \mathrm{og}$ fremefter. I foredragssalens montrer var udstillet albums, glasnegativer, bånd og sangbøger for at illustrere de historiske samlingers virkefelt. 
Plancheudstillingen stod i december måned på Det sønderjyske Landsbibliotek og blev således set af mange mennesker.

I forbindelse med jubilæet trak styrelsens formand, professor, dr. phil. Troels Fink sig tilbage og trådte tillige efter eget ønske ud af styrelsen, som han har siddet $\mathrm{i}$ siden samlingernes start. $\mathrm{Ny}$ formand blev landsarkivar Hans $\mathrm{H}$. Worsøe, mens Historisk Samfunds formand, Poul Andersen, blev valgt til ny næstformand. Sammen med lederen udgør de instituttets forretningsudvalg.

Ved undertegnedes tiltræden som lokalhistorisk konsulent den 1. august 1985 tog Historiske Samlinger samtidig afsked med sin grundlægger og mangeårige leder, fhv. landsarkivar Peter Kr. Iversen, der dog stadig har tilknytning til instituttet som medlem af styrelsen. Den billedsamling, som blev skabt på Peter Kr. Iversens initiativ, omfatter nu op imod 100.000 billeder, og det var således med god samvittighed, at Peter Kr. Iversen kunne takke af også på denne post for hermed at hellige sig sine mange andre interesser.

Historiske Samlinger er såvel den afgåede formand, Troels Fink, som den afgåede leder, Peter Kr. Iversen, megen tak skyldig.

Henrik Fangel

\section{Studieafdelingen ved Dansk Centralbibliotek for Sydslesvig, 1985}

Året 1985 har været præget af et spændende, men tidkrævende redaktionsarbejde og intensiv historisk forskning.

Bjørn Poulsen, stipendiat siden februar 1983, arbejder på et stort projekt, som har fået titlen "Det sydlige Slesvig i senmiddelalderen. Landbrug og marked «. Det forløbne år er gået med at udnytte en omfattende samling af kildemateriale på ca. 7.000 kartotekskort, fordelt på topografiske, saglige og personregistre, som er blevet samlet under projektets indledende fase. Nye kilder er inddraget i den igangværende analyse. Værkets første kapitler foreligger; de skildrer oprøret i 1472, adeligt og gejstligt gods i Sydslesvig, bønder, kromænd og møllere, landbrugsproduktion og dens afsætning samt håndværkere og handlende i byerne. Beskrivelsen af fjernhandelen fra Bredsted, Husum og Flensborg er påbegyndt. - En række problemer vedrørende toldregnskaber blev diskuteret i Sønderjyske Årbøger 1985. Bjørn Poulsen offentliggjorde desuden: "Arkæologi i Flensborg 1984" (i: META, Nyt om middelalderen 1985, s. 72-76), "Mønter $i$ den senmiddelalderlige danske agrarøkonomi« (i hikuin 11, 1985, s. 227-236), "Korn eller kvæg. Landbrugets specialisering i senmiddelalderen « (i: Bol og By 1985, s. 7-20).

Arkivar Lars N. Henningsen, stipendiat fra 1. september 1983 til 31. august 1985, afsluttede sit store og stofmættede værk "Provinsmatadorer fra 1700årene. Reder-, købmands- og fabrikantfamilien Otte i Ekernførde i økonomi og politik 1700-1770«. Lars Henningsens bog, der er på 471 sider, udkom den 15. november $1985 \mathrm{og}$ har fåt en række meget fine anmeldelser. Bogen er lovet anmeldt i nærværende årgang af Sdj. Årbøger. Studieafdelingen skylder Statens Humanistiske Forskningsråd og Sydbanks Fond tak for tilskud til denne udgivelse.

W. L. Christiansen, der fra 1. februar 1985 til 30. november 1985 var medarbejder ved Studieafdelingen i forbindelse med ABM (:Beskæftigelses- 
fremmende foranstaltninger), har afleveret og ordnet sit store privatarkiv (90 arkivkasser), skrevet første version af "Die Geschichte der SPF 1946-1954" og forfattet sine erindringer, som har fået titlen $» F r a$ blakket slesviger til dansk sønderjyde«. Hans ophold ved Studieafdelingen vil desuden resultere i nogle mindre samtidshistoriske artikler.

Den 1. december 1985 tiltrådte arkivar Klaus Egeberg som stipendiat og påbegyndte en historiografisk undersøgelse af den slesvigske lokalhistorie. Stipendiatopholdet måtte imidlertid ophøre allerede den 31. januar 1986, idet Klaus Egeberg blev udnævnt til landsarkivar i Grønland. Det kan dog forventes, at han vil udmønte de to måneders studier $\mathrm{i}$ artikelform.

Under redaktionsarbejdet med Studieafdelingens udgivelser skrev bibliotekslektoren bl.a. en tysk konklusion til Lars Henningsens bog og en række biografiske skitser til "Barn og ung i Sydslesvig 1900-1982«. Han holdt foredrag for vandrelærerne i Sydslesvig om "Christian Paulsen«, om "Aspekte unserer Landesgeschichte aus dänischer Sicht 1864-1920-1945-1955« på Amtsvolkshochschule Satrup og om "Die dänische Minderheit und ihre deutsche Umwelt " på Goethe-Institut $i$ København. Det sidste foredrag blev offentliggjort i Grenzfriedenshefte 1985, s. 196-208. Han arbejder nu på "Den danske Menighed i Flensborg«, der vil udkomme i efteråret 1987.

Jane Bossen, leder af Den slesvigske Samling, afleverede i januar 1986 sit manuskript "Helligåndskirken 1386-1986«, som er en indgående beskrivelse af bygningens og inventarets historie.

I december 1985 kunne Barn og ung i Sydslesvig 1900-1982 bind 1 og 2 (510 sider) udleveres til ca. 450 subskribenter. Bogens officielle udgivelsesdag blev den 10. januar 1986. Denne dag markeredes ved en reception. De to nye bind med barndoms- og ungdomserindringer dækker hele Sydslesvig fra Tønning og Husum over Kollundmark til Agtrup og Ladelund, fra Ladelund østover til Harreslevmark, Flensborg og Tarup og sydover til Strukstrup, Slesvig og Rendsborg. Det er 16 bidrag fra godt en halv snes lokaliteter, fra land og by og fra alle sociale lag. De to bind, der har fåt en særdeles fin modtagelse af pressen, er tilegnet Lars H. Schubert (1907-1984). Også dette værk er lovet anmeldt $i$ denne årgang af Sdj. Árbøger. Studieafdelingen takker "Kong Frederik og dronning Ingrids fond til humanitære og kulturelle formål« og »Det unge Grænseværn« for tilskud til denne udgivelse.

Også i det forløbne år har en række danske og tyske historikere søgt og fået vejledning i deres forskning. Flere af dem har haft brug for en arbejdsplads på Studieafdelingen og har trukket på Studieafdelingens og Centralbibliotekets muligheder for adgang til information.

Johann Runge

\section{Institut for Grænseregionsforskning, 1985}

I lighed med tidligere år var arbejdet i 1985 igen præget af en bred vifte af forskningsprojekter. Takket være støtte fra såvel offentlig som privat side, herunder forskningsfonde samt kontraktforskning lykkedes det at fastholde et højt aktivitetsniveau. 
Inden for det samfundsvidenskabelige område fortsatte de igangværende undersøgelser om uddannelses- og beskæftigelsesforholdene i Sønderjylland. En del af disse undersøgelser har også udløbere til andre egne af landet. Nyt i den forbindelse er et projekt om erhvervskvalifikationer. Ny teknologi og hurtige strukturændringer medfører således hele tiden ændrede kvalifikationskrav inden for de forskellige erhverv. Ofte er det vanskeligt for uddannelsesinstitutionerne at leve op til disse nye krav. Et hovedformål med undersøgelsen er derfor at kortlægge virksomhedernes omstilling og at præcisere og formidle de derved forbundne nye kvalifikationskrav til medarbejderne. Undersøgelsen vil bygge på case-studier fra virksomheder i og uden for Sønderjylland.

Af andre projekter kan nævnes undersøgelser af den offentlige sektor nord og syd for grænsen, de økonomiske konsekvenser af en fast Storebæltsforbindelse, den dansk-tyske grænsehandel, forbrugsvarernes vej fra producent til forbruger i Nord- og Sydslesvig samt økonomiske prognoser for Sønderjylland.

I 1985 blev følgeforskningen i det regionale tv-forsøg TV-Syd også bragt til afslutning. Hovedindsatsen lå på gennemførelsen af en større spørgeskemaundersøgelse. Den skulle dels belyse modtagelsen af TV-Syd blandt regionens befolkning og dels supplere den tidligere gennemførte undersøgelse af medievanerne i Syd- og Sønderjylland. Parallelt hermed er der blevet gennemført en undersøgelse af mediebrugen blandt det danske mindretal i Sydslesvig. Resultaterne af disse undersøgelser blev offentliggjort i årets løb.

Inden for det humanistiske område fortsatte projekterne om det danske og det tyske mindretals historie, stationsbyernes udvikling i Sønderjylland 18401940 , mødet mellem sprogene i den dansk-tyske grænseregion og folkesangen i Sønderjylland. En liste med udgivelser af resultater herfra såvel som de øvrige projekter kan rekvireres ved henvendelse til instituttet.

Udover forskningen har instituttet arbejdet med informations- og oplysningsvirksomhed, bl.a. formidlet gennem det lille tidsskrift PLUK, der i tre numre årligt orienterer om forskning $\mathrm{i}$ eller om Sønderjylland. Hertil kommer talrige foredrag, artikler, radioindlæg og besvarelse af henvendelser samt deltagelse i faglige konferencer.

Henrik Becker-Christensen

\section{Museer}

\section{Haderslev Museum}

Arkæologisk blev 1985 et yderst givtigt år med mange spændende fund og udgravninger. Blandt de vigtigste skal nævnes en rigt udstyret grav fra den ældre bronzealder ved Hønkys (Rødekro Kommune), en boplads fra samme periode ved Højgaard (Gram Kommune) samt grave og boplads fra jernalderen ved Hjemsted (Skærbæk Kommune). Endvidere skal nævnes 2 fund af danefæ: et lille lerhoved fra den ældre jernalder fra Grønninghoved (Christiansfeld Kommune), og en stor møntskat ( $7 \frac{1}{2} \mathrm{~kg}$ ) fra 1600-tallet, fundet ved Sdr. Vollum (Bredebro Kommune). 


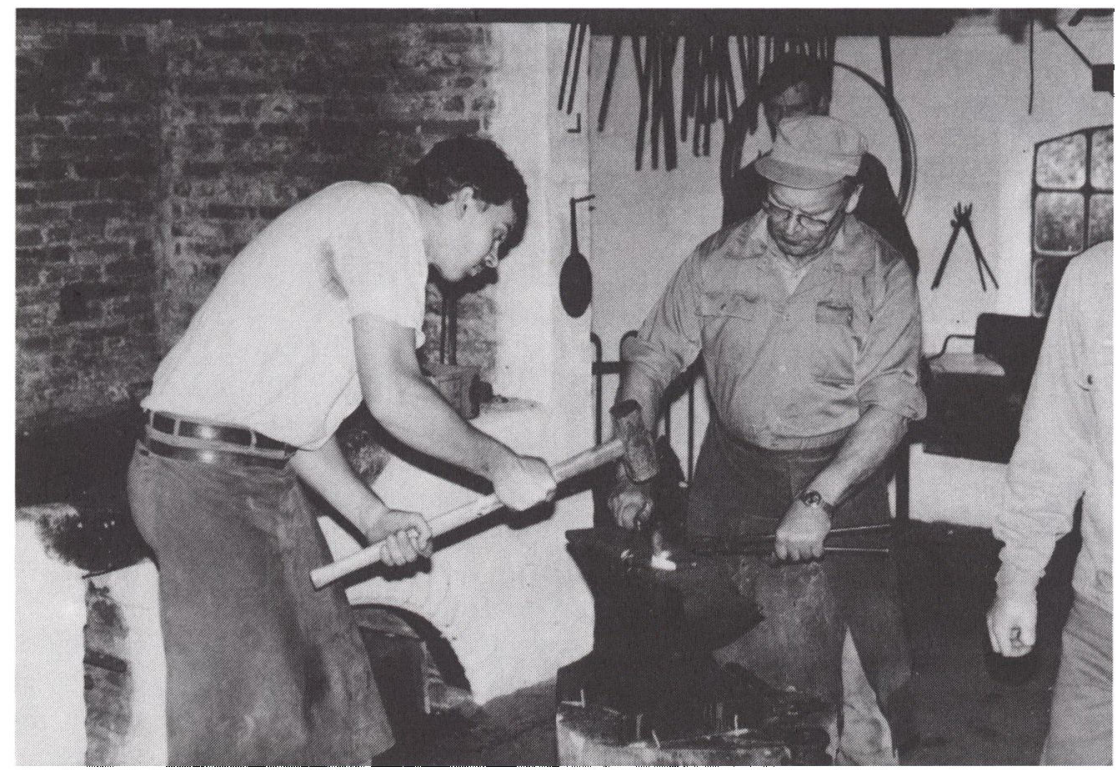

I skolernes efterårsferie var der demonstration af smedning $i$ Torning smedje. (foto: museet)

Af særudstillinger har der $\mathrm{i}$ årets løb været afholdt 8 , hvoraf Haderslev Kunstforening tegner sig for de $3+1$ i samarbejde med museet. Af disse skal især fremhæves en udstilling med keramikerne Heidi og Åge Birck, en udstilling af rav gennem tiderne, en stor etnografisk udstilling om kongedømmet Bhutan i Himalaya samt udstillingen "Hvad vi fik og fandt» om Museets nyerhvervelser gennem de sidste 5 år. Af nyheder i den permanente udstilling skal nævnes indretning af Torning smedie i frilandsafdelingen samt en nyordning af samlingen af landbrugsredskaber. Årets samlede besøgstal blev 25.522. Foruden udstillingerne på museet har der været arrangeret en række mindre særudstillinger i pengeinstitutter, på plejehjem m.v.

Ud over udstillingerne har der på museet været afholdt foredrag, koncerter, folkedanseropvisning m.v., ligesom museets medarbejdere har medvirket ved arrangementer uden for museet.

Af publikationer er der foruden informations- og skolemateriale udsendt nr. 2 af tidsskriftet »Lægæst «, en ny vejledning til Frilandsmuseet samt årsberetning 1985. Til sidstnævnte henvises for supplerende oplysninger om museets drift. Den tilsendes gratis ved henvendelse til Haderslev Museum. 


\section{Aabenraa Museum}

1985 har på flere måder skilt sig ud fra de foregående år. Først og fremmest har hele museets virksomhed været tilrettelagt efter Aabenraa's byjubilæum, og dertil har både kommune og stat ydet særlige tilskud. Dernæst fik museet efter ansøgning midler fra Statens Museumsnævn til nogle helt centrale opgaver, som ellers ikke kunne klares.

De mange aktiviteter, der er udfoldet i år, har dog langt fra kunnet udføres af museets faste personale alene. Netop i jubilæumsperioden har kommunen stillet personer under beskæftigelsesordninger til rådighed i et omfang, som bliver helt uopnåeligt i 1986.

I foråret 1985 kunne ombygningen af den tidligere kustodebolig endelig afsluttes. Udstillingsrummet blev dermed klar i god tid før by-jubilæet, hvor det viste sig uhyre velegnet ved den første særudstilling.

\section{Undersøgelser, forskning og indsamling}

Hovedparten af undersøgelserne udspringer normalt af enten udstillingsformidlingsopgaver, eller de består $\mathrm{i}$ små plukvise undersøgelser $\mathrm{i}$ forbindelse med gaver eller forespørgsler. Det er værd at fremhæve, at dette udadtil næppe synlige arbejde er den nødvendige betingelse for, at de losrevne genstande kan placeres $i$ forhold til den almene historie og de mennesker og den egn, som de har været en del af.

Som forberedelse af jubilæumsaktiviteterne blev et stort antal (ca. 350) kunstneriske fremstillinger af Aabenraa fra ca. 1800-1985 registreret og fotograferet. De omfatter næsten udelukkende billeder i privat eje i Aabenraa, og tilsammen giver registreringen en god oversigt over kunstnere og de motiver, man til forskellig tid har yndet. Udover bevaringsværdien vil denne oversigt danne et godt grundlag, når museet eller andre søger at arbejde videre med eller indsamle by-billeder.

Den oversigt over kilder til byens middelalderlige topograf, som blev udarbejdet sidste år, fik i år den følge, at de arkæologiske undersøgelser i Vestergade kunne fortsætte, efterhånden som de, ialt fire, huse forsvandt. Haderslev Museum forestod udgravningerne, mens Aabenraa Museum sørgede for formidling, og for at et stort antal løsfund blev udgravede. Det mest "positive« resultat af udgravningerne i Vestergade er, at gaden først for alvor bebygges i 1600-årene. Indtil da var her højst et par værksteder, og arealerne blev brugt til affald.

Årets mest omfattende undersøgelse gjaldt imidlertid museets egne genstande, nemlig den betydelige samling af oversøiske genstande. Hertil havde Statens Museumsnævn bevilget etnografisk bistand $\mathrm{i}$ tre måneder, idet den type samlinger dels er et helt uopdyrket felt, dels kan fortælle noget om, hvad de danske søfolks møde med det fremmede og eksotiske indebar.

Godt 700 genstande, der stammer fra Aabenraa-søfarten blev fotograferede og deres oprindelsessted, fremstilling og brug bestemt. Fremhæves kan det, at den sagkyndige gennemgang bragte nogle meget sjældne og værdifulde ting for dagen. Det drejede sig især om store fotoalbums fra Kina og nogle håndmalede japanske billedruller med fortællinger om ainuer m.m. 
Gaver og erhvervelser

Museet kan glæde sig over, at den jævne strøm af gaver fortsætter. De kommer fra ret forskellige kredse. En meget betydelig del repræsenterer den kreds, som kan benævnes søen og slægten, nemlig efterkommere efter eliten af købmænd, redere, kaptajner og skibsbygmestre.

Igennem snart mange år har museet således fra en dame bosat $i$ Tyskland modtaget billeder, erindringer, notesbøger fra kaptajnerne Krabb, Mathiesen og Ulderup, og langere tilbage senator Jürgen Ahlmann. I år blev der kopieret fotografier fra Stentoftgård, og modtaget fotografier og notesbøger fra samme sted, samt endelig en stamtavle over slægten Ahlmann.

Ved siden af disse minder har museet $\mathrm{i}$ år modtaget fotokopier af breve, digte og erindringer fra en kaptajnskone, samt breve fra en skibsdreng på Colibri 1853-55.

Til samlingen af sømandssouvenirs blev føjet en uhyre sjælden gondol med roere, alt lavet af kryddernelliker. Fra et yngre slægtled modtog museet desuden en meget fyldig og velbevaret samling af pigetøj, kjoler, forklæder, undertøj samt fotografier. Både forarbejdning, kvalitet og enkeltheder som forklæder og silkedansekjoler kaster lys over både miljøets velstand og over den opdragelse, som de små piger fik i tiden 1915-30.

Ved siden af disse traditionelle giverkredse modtager vi heldigvis også henvendelser fra arbejdere. I ét tilfælde fik museet således lov til at være med i udvælgelsen fra et dødsbo, og herved sikredes nogle ellers oversete husholdningsredskaber, et henkogningssæt og en symaskine. De havde været centrale $i$ den udprægede selvforsyning, som et typisk arbejdsmandshjem $i$ Løjt havde været afhængig af $i$ årene 1930-50. I øvrigt kan nævnes olietryk, bl.a. et kejserbillede fra ca. 1915, reproduktioner, kontrabøger fra en Aabenraa-købmand og en smeds delvist håndlavede cykelværktøj.

Af sparehensyn er der kun gjort indkøb til kunstafdelingen, og beløbet er yderligere halveret til kr. 10.000. På Grænselandsudstillingen er købt: Jes Schrøder "Mutter Germania", (lille skulptur i træ, bemalet gips), Maria Lüders Hansen »Billede«, oliekridt abstrakt, et helt ny-brud for hende. Fra museets egne udstillinger erhvervedes en bladcollage, "Jomfru Fanny» af Susanne Tvermoes.

\section{Bevaring}

Takket være en bevilling på 26.000 fra Statens Museumsnævn blev det i år muligt at fortsætte restaureringen af museets enestående samling af skibsportrætter. Ikke bare i lokalhistorisk sammenhæng er den store samling central, men også i dansk søfartshistorie. Blandt andet er de to billeder fra kinesiske flodmundinger, der nu er blevet restaurerede, i sig selv enestående og sjældne. Den sidste del af bevillingen gik til konservering af nogle af de bedste af halvmodellerne i billedkasser. Om dem ved vi, at de er fremstillet af søfolk, og at tilsvarende savnes på landets hovedmuseum, på Kronborg.

\section{Sarudstillinger og anden formidling}

Årets første særudstilling tog udgangspunkt i et materiale, halm, som for blot 40-50 år siden blev anvendt overalt, til tagtækning, til træsko, til kurve og hatte og meget mere. Udstillingen var fremstillet af Langelands Museum, og 


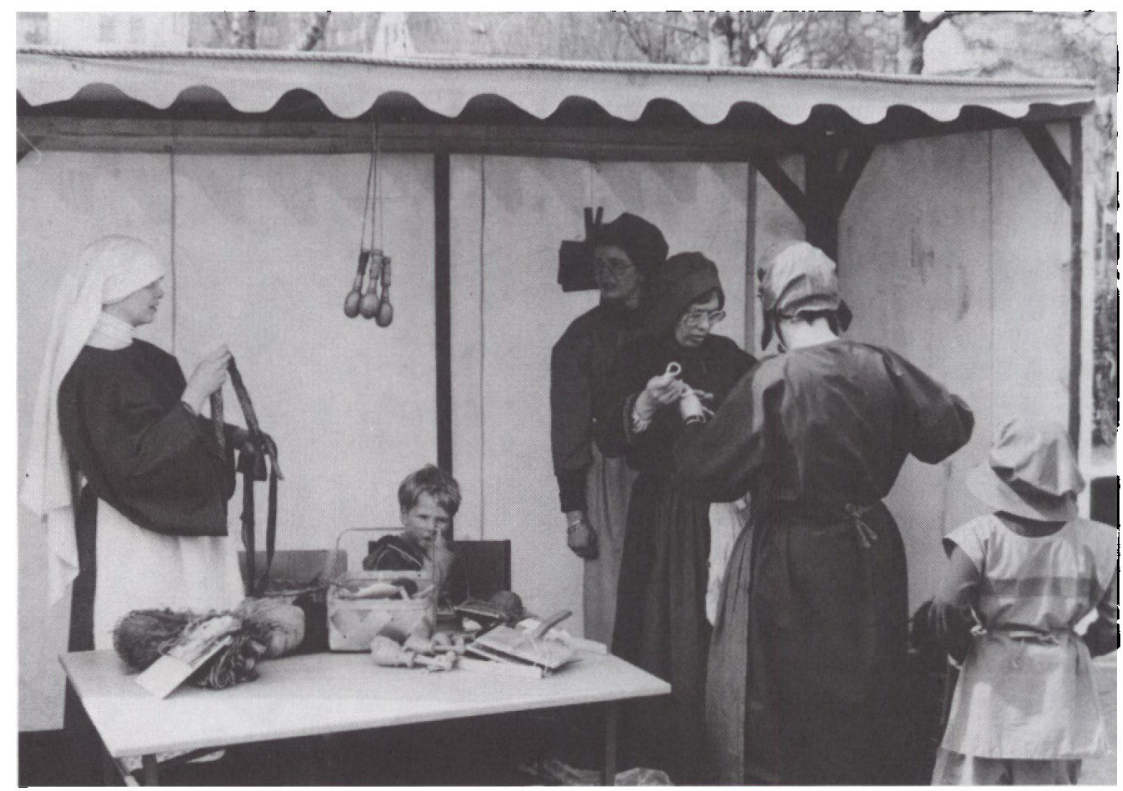

Under Aabenraas 650 drs jubilaum, i dagene 3.-4. maj 1985, var Sonderjyllandshallen og hele H.P.Hanssens Gade omdannet til en stor og velbesegt messe for byens erhverv.

Foran museet skabie en rakke frivillige $i$ samarbejde med museet et lille marked, der med dragter og boder skulle give en fornemmelse af middelalder. (foto: museet)

den gav en både konkret og perspektivrig indsigt $\mathrm{i}$ de omfattende tekniske ændringer, der har gjort halm næsten overfledig. I besøgstal blev udstillingen en stor succes.

De to næste særudstillinger blev åbnet til byjubilæet 1 . maj. I den ene forsøgte vi at give et billede af livet i Aabenraa i middelalderen ud fra de sparsomme fund, der findes her og på Nationalmuseet. Udstillingen dannede samtidig baggrund for udgravningerne $i$ Vestergade, hvorfra de friske fund løbende blev inddraget.

Den anden udstilling "Aabenraa Billeder 1800-1985«, lånt fra private hjem, blev vist $\mathrm{i}$ den nye sal. I den var repræsenteret både store kunstnere som Franciska Clausen, flere lokalkendte og mange amatører, herunder et par børn.

Endelig indgik museet ved byjubilæet $i$ et samarbejde med Nationalmuseet og stiftamtet om den særudstilling, der blev lavet på Brundlund Slot om bygningens historie og den nye viden, som de bygningsarkæologiske undersøgelser under restaureringen havde bragt frem.

Af kunstudstillinger har der været tre: Først Walisiske keramikere, arrangeret af British Club og med støtte fra British Council. Det var dejlig brugskeramik, som mange ikke bare så på, men også købte. Endvidere efter sommerferi- 


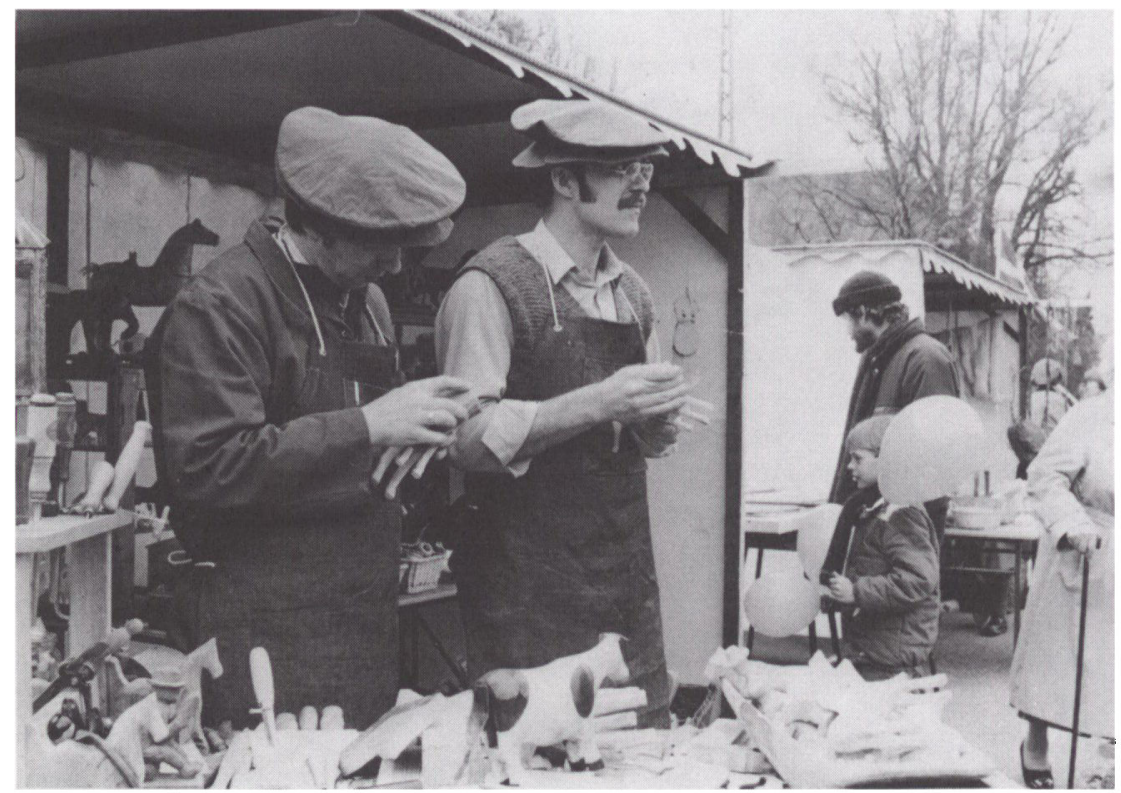

Her skarer de to brodre Vinther-Pedersen legetojsdyr, mens Elin Olsen, Inger Nielsen, Susanne Ảberg og Gunhild Eeg på forrige side spinder og vaver bånd. (foto: museet)

en to yngre kunstnere Ole Pultz og Dea Enna, og i efterårsferien Susanne Tvermoes. Især den sidste har med sine helt specielle blad-billeder over sagn og eventyr, samt sine dukker fået et stort begejstret publikum.

Årets sidste særudstilling "Fra børnenes verden « føjede sig til det traditionelle juletræ i december måned. Den viste en meget righoldig privat samling af købelegetøj ca. 1880-1930, suppleret med børnetøj og billeder af børn.

Ved siden af særudstillingerne har museet arbejdet med en række andre formidlingsformer. For at fejre byjubilæet udgav museet i samarbejde med Amtscentralen et Byhistorisk Atlas. Hæftet er udarbejdet af Henrik Fangel og Helle Denckert, og det giver både en konkret og alsidig oversigt over byens historie og et spændende undervisningsmateriale bygget over kort og billeder.

Ved messedagene først i maj arrangeredes på H. P. Hanssens Gade et "Middelaldermarked«. Det var resultatet af et usædvanligt godt samarbejde med nogle frivillige, der udfyldte hver sin bod: slagter, smed, keramik, træskæring, væuning og spinding. Markedet blev et farverigt åndehul og tilslutningen efter fortjeneste. Som helhed gav det løfter om, at den slags arrangementer, der henvender sig til næsten alle, vil kunne fortsætte, så museet får flere i tale. 


\section{Museet på Sønderborg Slot}

Museets bestyrelse og faste personale var uændret i 1985. Museet har som sædvanligt $\mathrm{i}$ de senere år beskæftiget 7 langtidsledige og en civil værnepligtig foruden ekstra medhjælp. Uden denne hjælp var det ikke muligt at opretholde hverken den ret store åbningstid, hjælpen til skoler eller museets øvrige aktiviteter. Nu lykkedes det at bevare et rimeligt aktivitetsniveau og samtidig opnå et besøgstal på 90.000 ligesom året for.

Til de aktiviteter, der markerer museets virke udadtil, hører særudstillingerne. I 1985 vistes samme antal som i de foregående år. Den store sommerudstilling var foranlediget af 40-året for 2. verdenskrigs afslutning i 1945. Da der var kommet en central opfordring til alle museer, arkiver, biblioteker m.v. om at lave udstillinger $i$ denne anledning, var mulighederne for lån stærkt begrænsede og interessen nok også mindre, end man kunne have ventet. De største og værdifuldeste lån kom derfor fra private. Derimod betød udstillingen, at museet modtog adskillige gaver, både genstande og billeder, fra 2 . verdenskrig.

En særudstilling, der trak mange gæster, var en opstilling af en række små, livagtige og detaljeret opbyggede scener med emner fra Nordens historie. De var opbyggede som kukkasser, hvor man så ind ad små vinduer på større scenerier, befolkede med tinfigurer. Alle var udførte med stor akkuratesse og historisk nøjagtighed af medlemmer af foreningen "Chakoten« og kom til at stå hele vinteren over.

Blandt årets øvrige særudstillinger har der været en kunstudstilling af sammenslutningen »Kammeraterne» sm.m. Danfoss Kunstforening, en udstilling af østtysk legetøj fra Erzgebirge, samt i vintermånederne museets traditionelle legetøjsudstilling og planche-udstillingen »Midvinter og Masketid«. Af andre arrangementer kan nævnes en foredragsrække sammen med Historisk Samfund for Als og Sundeved, koncerter, arrangerede af Sønderborg Musikforening eller af forskellige kor og en rakke møder, arrangerede bl.a. af Bedre Bymiljø, Lokalhistorisk Arkiv, Slægthistorisk Forening, Folkeuniversitetet og Historisk Samfund for Sønderjylland.

Udover de mange genstande, der belyste krigen 1939-45, modtog museet talrige andre gaver. En af disse gav anledning til indretning af et helt rum, museets kniplingsstue, med en nu specialbygget montre og nye vægplancher. Det drejer sig om den enestående sjældne samling af kniplinger, der skænkedes museet af fru I. Ragozcy og grosserer L. Ragozcy, hvis mor, fru L. Ragozcy havde samlet størstedelen af de smukke kniplinger. Den prægtige samling blev præsenteret i sit nye rum ved en højtidelighed, der blev overværet af Dronning Ingrid. Denne fornemme gave har givet anledning til en hel række besøg af særligt interesserede.

Blandt de mange andre gaver kan fremhæves en del tekstiler og adskilligt værktøj, især fra smede- og snedkerværksteder. Til de historiske samlinger er indgået nogle uniformer og flere genstande fra krigen 1914-18. Endelig er indkøbt en række kolorerede stik fra 1864, nogle tegninger af C. D. Gebauer og et maleri af Martin Quist samt nogle mønter og medaljer.

Árbogen "Nordslesvigske Museer« udsendte bind 12 som et festskrift til lederen af museerne i Tønder, dr. Sigurd Schoubye i anledning af dennes 70- 
års dag. Årbogen, der redigeredes af J. Slettebo, blev med sine 206 sider og 17 artikler, foruden beretning og en bibliografi over S. Schoubyes arbejder, den hidtil største i rækken. Fra museet bidrog fru Inge Adriansen med $»$ - men ørnen, den bygger i fjeldet ud « om illustrationer til folkevisen om $\mathrm{Chr}$. II som den fangne ørn og om slottets vandkunst med dette motiv, Tove og J. Slettebo skrev $\mathrm{i}$ fællesskab om en sjælden nyerhvervelse til museet, en dåbskjole fra ca. 1760 , og J. Slettebo leverede foruden årsberetningen også artiklen "To ungdomsvenner - J. P. Møller og C. W. Eckersberg». Desuden byggede H. Roesdahls artikel "Hollandske vægfliser på Als « på materiale i museet. Årbogens emner var iøvrigt lige så alsidige og vidstpændende, som Sigurd Schoubyes museumsinteresser altid har været, og bogen indledtes da også med en hilsen fra formanden for Sønderjyllands Kunstmuseum, viceamtsborgmester Dycke Hoff og med en billedkavalkade omkring Schoubye ved nogle af hans mangfoldige aktiviteter.

Inge Adriansen har i årets løb publiceret nogle boganmeldelser og artikler, bl.a. på tysk (om fjerfugle) og engelsk (om museumsrundvisning) samt har med Henrik Lundbak, på Amtscentralen udgivet en diasserie om "Besættelsesårene i Sønderjylland « i tilknytning til museets store sommerudstilling. J. Slettebo har sammen med sine nordslesvigske kolleger fortsat arbejdet med en langtidsplan for amtets museumsvæsen, en plan, der blev forelagt og drøftet på to møder $\mathrm{i}$ amtsmuseumsrådet.

Museet har fortsat deltaget $i$ en rakke forskningsprojekter, forst og fremmest Den danske Industri-registrering samt i Teglværksprojektet og det fælles Vadehavsprojekt. Desuden er samarbejdet med en lang række historiske foreninger og institutioner foruden Amtscentralen for Undervisningsmidler, Skolecentralen i Sønderborg, Sønderborg bibliotek og Lokalhistoriske Arkiv fortsat. Det nære samarbejde med Historisk Samfund for Als og Sundeved består ubrudt. Historisk Samfund er som hidtil repræsenteret i museets bestyrelse, mens museets inspektør er sekretær i Historisk Samfund.

J. Slettebo

\section{Tonder Museum}

Redaktionen beklager ikke at have modtaget årsberetning fra Tønder Museum og Sønderjyllands Kunstmuseum.

\section{Midtsenderjyllands Museum}

Da museet åbnede Palmesøndag, kunne vi fremvise en lille udvidelse af den "permanente« udstilling, idet der på 1 . etagen var blevet opbygget en mindre astronomiudstilling. Udstillingen, der er lånt fra Naturhistorisk Museum i Arhus, fortæller om vort solsystem og om chancen for at finde liv uden for Jorden.

Da vi heller ikke $\mathrm{i}$ år har haft mulighed for at foretage udgravninger i Gram Teglværksgrav, har vi benyttet tiden til at ajourføre registreringen af museets samlinger i takt med, at de blev overflyttet til "Hvalhallen « $i$ den gamle tæppefabrik. Denne hal blev officielt åbnet $\mathrm{i}$ juli måned af viceamtsborgmester 
Dycke Hoff, der gav museet gode ønsker med på vejen, til det arbejde, der nu skal foregå - nemlig konservering af hvalerne fra Gram-leret. Inden dette praktiske arbejde kan begynde, ligger der dog et stort undersøgelsesarbejde for at klargøre, hvordan knoglerne skal behandles, for ikke at blive nedbrudt af den farlige pyrit, der findes i dem.

Bestyrelsen for museet har ansat Lizzi Thamdrup, Seem i stillingen som konservator.

Som udgangspunkt for konservatorens arbejde har museet ved hjælp af udefra kommende midler, kunnet betale to hovedfagsstuderende for at udarbejde en detaljeret rapport over Gram-lerets kemi.

I løbet af året var museet, sammen med amtets øvrige museer, med ved en udstilling på Vojensmessen og med $\mathrm{i}$ opbygningen af det fælles: "projekt skurvogn«. Museerne i Sønderjylland har nemlig indkøbt en stor skurvogn, hvori der vil blive indrettet udstillinger, der kan præsenteres ved markeder, ringriderfester og på skoler. Den spændende ydre dekoration blev præsenteret i efteråret.

En af museets særudstillinger bør omtales lidt nøjere. Den opstod gennem et samarbejde med Greenpeace og hed "Red Hvalerne«, og både museets særudstillingslokale og Hvalhallen måtte bruges i udstillingen. I særudstillingslokalet udstillede vi, foran et $8 \mathrm{~m}$ langt "regnbuetæppe«, skelettet af en

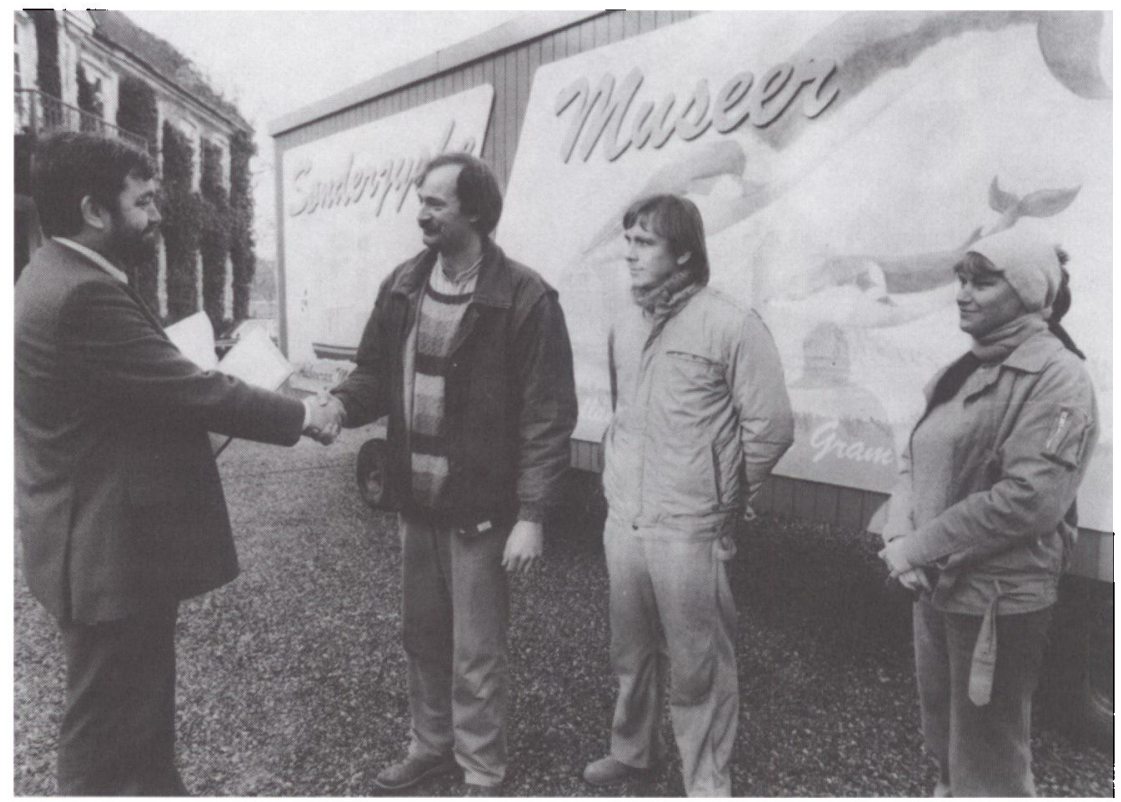

Det rullende museum blev indviet den 7. maj 1986. Den kunstneriske udsmykning er betalt af Sparekassen Sonderjyllands fond. Marketingschef Bjarne Jorgensen, Aabenraa overrakker checken til museumspadagog Martin Abrahamsson, Gram. Til hojre ses kunstnerparret Lene og Allan Christensen, Arnum, der har udfort malerierne. 

døgling hval, der i 1970'erne strandede på Rømø. Den øvrige del af lokalet blev brugt til fremvisning af Greenpeace plakater, trøjer, badges og meget mere. En lysbilledserie fortalte om organisationens arbejde, der også blev belyst gennem film.

I Hvalhallen udstilledes det $14 \mathrm{~m}$ lange skelet af en af kaskelothvalerne fra Henne Strand, og to aftener blev der her vist lysbilledforedrag og sunget gamle hvalfangersange.

I eftersommeren deltog Martin Abrahamsson og Flemming Roth i planlægningen og undervisningen af et "naturhold« på Rødding Højskole. Det er meningen, at vi også næste år skal deltage $i$ dette spændende formidlingsarbejde.

Sidst på året, i december måned, blev kælderetagen på museet oversvømmet, på grund af større mængder smeltevand! Resten af året gik med en besværlig oprydning efter dette kedelige uheld, der ødelagde en del materiel.

Ved udgangen af året måtte museet desværre sige farvel til sin formand, Hans Schmidt, Sandet, idet han ikke genopstillede til amtsrådet. Også et andet bestyrelsesmedlem, der har fulgt museet fra allerførste færd, Ove Hansen, trak sig tilbage fra bestyrelsen. Vi vil savne begge.

\section{Sarudstillinger}

"Naturen kom før teknikken«, en udstilling lånt på Naturhistorisk Museum i Århus.

Marmorskulpturer og textiler udført af kunstnerne Lis Andersen og Bodil Fontain.

Brugskunst og unikke ting i stentøj og porcelæn udført af Anders Birkegaard, Rødding. Billedvævning og applikation af Sanne Støvlbæk, Rødding samt oliemalerier af Viggo Andersen, Brændstrup.

Malerier og skulpturer af Hanne Elf, Køln.

Besøgstal var ca. 12.000 .

Flemming Roth

\section{Museet Holmen}

\section{Udstillinger}

Hovedudstillingen på museet i 1985 var "Leddet er af lave« - om sønderjysk forsvar fra oldtid til nutid. Udstillingen var produceret af Haderslev Museum og Museet på Sønderborg Slot i fællesskab og vistes i Løgumkloster som det 3. sted i landsdelen. Samtidig med denne blev museets udstilling om det middelalderlige Løgumkloster åbnet i klostrets stueetage.

I forbindelse med det årlige bogloppemarked udstillede Marianne Permin, Kavaletten og Jette Rasmussen keramik, Bente Moesmann og Hanne Knudsdatter tekstile arbejder - mens museet viste en nyerhvervet samling af gammelt legetøj. 
Museet har endvidere været behjælpelig med ophængning af en udstilling af Adi Holzers og Niels Helledies værker i forbindelse med Løgumkloster Højskoles 25 års jubilæum i november.

\section{Samlingerne}

Museet har i årets løb erhvervet en række værdifulde genstande, såvel til den lokalhistoriske samling, som til samlingen af dokumentationsmaterialer vedr. moderne kirkekunst. Over 200 numre er indgået i museets registratur - lige fra katolske messehagler til gyngeheste. Samtidig er der påbegyndt en registrering og konservering af genstande fra Lokalhistorisk Forenings indsamlinger. Nordisk Kirkeprojekt er blevet beriget med adskillige kirkemodeller og skitser til byggeprojekter, diassamlingen er ordnet og opstillet i tilgængelig form, ligesom vores håndbogssamling er vokset støt. I årets løb er færdiggjort programmet for en konference om moderne kirkearkitektur i samarbejde med Kirkefondet.

Omkring nytårsskiftet 85-86 opstilledes en permanent lokalhistorisk udstilling samt en udstilling af Nordisk Kirkeprojekts samlinger.

Det omfattende arbejde med registrering og udstillingsopbygning er blevet muligt bl.a. gennem fondsstøtte fra Sønderjyllands Amts Museumsråd, HvassFonden, ekstraordinært tilskud fra Løgumkloster Kommune - samt en stor indsats fra museets ulønnede arbejdsgruppe.

I begyndelsen af 1986 fratrædte mag. art. Birgitte Wistoft som museumsleder for at overtage en ny stilling i Selskabet for Nordisk Kulturhistorie. I en overgangsperiode, der benyttes til at undersøge mulighederne for at sikre museets status og økonomi fremover, er ledelsesarbejdet fordelt mellem bestyrelsens medlemmer, bistået af en kreds af frivillige medarbejdere. Den daglige administration udføres af en deltidsansat forretningsfører, Henry Gaarde.

Jens Kristian Krarup

\section{Lokalhistoriske foreninger, samlinger og arkiver}

\section{Lokalhistoriske Arkiver og Samlinger i Sønderjylland (LASS) i 1985}

Ved årsmødet talte arkivar Klaus Egebjerg om, hvad lokalarkiverne kan finde på Rigsarkivet og andre større arkiver.

Der var igen fotokopieringskampagne i 1985 , og der blev solgt ca. 21.000 kopier af kirkebøger og andre arkivalier i Det Sønderjyske Landsarkiv til de lokale arkiver.

LASS deltog også igen i 1985 med en stand på Fællesdyrskuet i Åbenrå. Dyrskuets emne var milieu, og LASS havde en udstilling over temaet landsbymilieu med billeder fra Løjt i øst og Møgeltønder i vestkanten af området. En folder i 500 eksemplarer om, hvad et lokalhistorisk arkiv er, blev totalt "udsolgt«. Der var også udarbejdet en plakat med advarsel om ikke at kaste arkivsager bort.

Den 1.8.1985 ansattes lektor Henrik Fangel som leder af den institution, som nu hedder Institut for sønderjysk lokalhistorie og samtidig som lokalhistorisk 


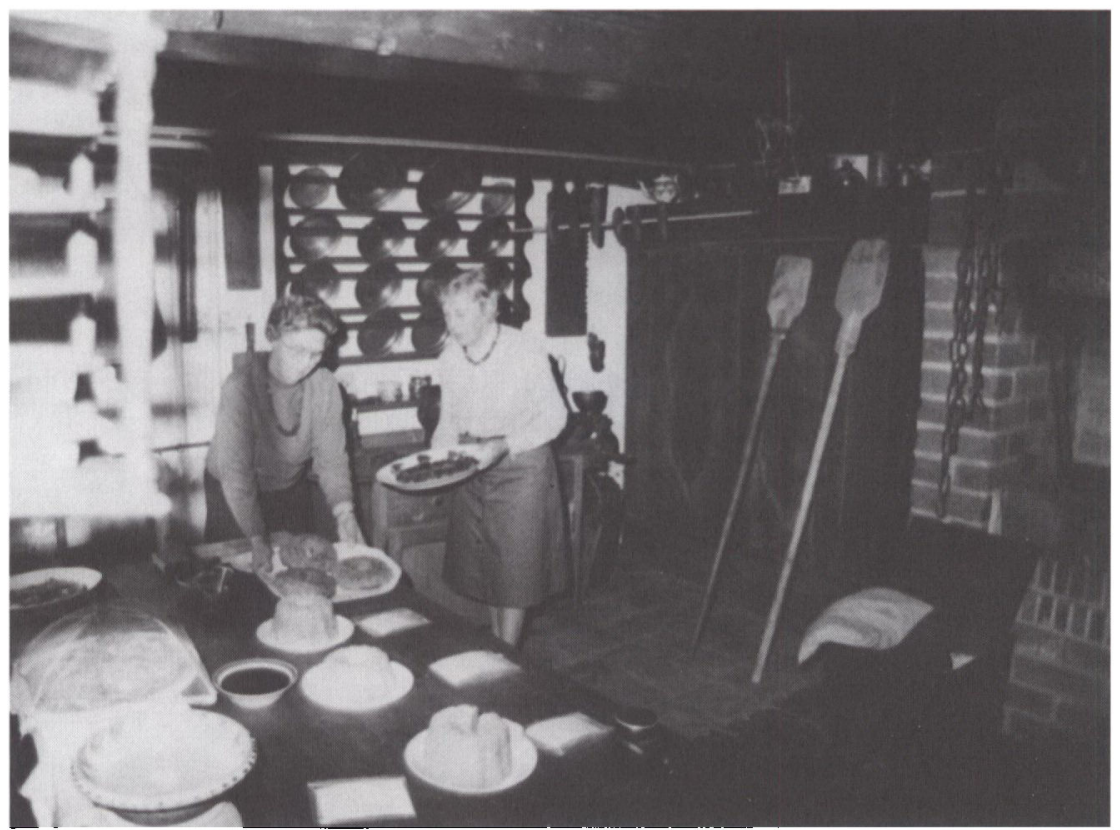

Sigrid Rasmussen og Anne-Helene Michelsen har udstillingen om Middelaldermad klar. (foto: Helic, Aabenraa)

konsulent for Sønderjylland. LASS har allerede haft glæde af samarbejdet, og er glade for dette aktiv i det lokalhistoriske arbejde i Senderjylland. Foreningens medlemmer aflagde besøg $i$ instituttet.

Årets kursusvirksomhed var en skuffelse. Både et tilbudt grundregistreringskursus og et tilbudt billedregistreringskursus måtte aflyses på grund af for få deltagere. De få, der meldte sig, fik besøg i deres eget arkiv af LASS' egne instruktører.

Den lokalhistoriske dag gik til Vesteregnen med besøg på arkivet $\mathrm{i}$ Tønder og på Kiers gård i Højer samt Højer Mølle.

LASS har fået tilbudt en plads i styrelsen af Institut for Sønderjysk lokalhistorie og har valgt formanden, Ester Feddersen, Tinglev, til denne opgave.

Der er nu 41 lokalhistoriske arkiver og foreninger, som er medlemmer af LASS.

Krista Lyngby

Samlingen af arbejdsredskaber og bondemøbler på Jacob Michelsens gård i Kolstrup

I anledning af Aabenraas 650 års jubilæum arrangeredes der den 18. og 19. maj udstilling om retter fra Middelalderen. Den besøgtes af 234 gæster. Under 
ledelse af fru Irmi Kjems, Harreslev holdtes der i juli måned spindekursus med 12 deltagere.

Sidst i september holdtes den årlige udstilling over emnet: "Hvorledes bønder byggede og boede i gamle dage«. Der blev hugget tømmer med en »biløkse» af tømrer Ingemann Rasmussen. Håndlavede mursten blev frembragt af teglværksarbejder Claus Marquardt, og jydepotter blev håndlavet i køkkenet af Agnethe Schmidt. Inde i stuen forklarede Senius Tiedemann gårdens stensamling.

Også i år har vi haft glæde af bistand fra en langtidsledig, Synnøve Stenholdt, som har været en god hjælp, når "Samlingen« skal holdes intakt.

Af gaver har vi i år modtaget følgende: En spidshakke af Helge Stenholdt. To vogndækkener af fru Marie Mathiesen, Hjolderup. En sav - en jernvinkel og et drejebor af Hans Aalling.

Med hensyn til fremtiden er det vort håb, at de forhandlinger, der føres med amt og kommune må få et gunstigt udfald, således at Jacob Michelsens gård kan bevares ud i fremtiden.

Niels Chr. Michelsen

\section{Historisk forening for Vis herred, Bov museum}

Den 4. maj 1985 åbnedes en særudstilling på Bov museum i anledning af 40årsdagen for Danmarks befrielse. Vort ønske var, at man også i Bov kommune, der spillede så stor rolle som det vigtigste grænseovergangssted, skulle mindes de bevægede dage.

Museumsudvalget havde søgt at finde frem til så mange som muligt af de nulevende gamle modstandsfolk fra Bov kommune. Det lykkedes os at komme i forbindelse med de fleste af dem. Vi fik en stor samling af skriftlige beretninger og båndoptagelser samt fotos af mange af grupperne. En del af materialet blev benyttet ved udstillingen, men alt blev arkiveret til brug for en kommende tids historieforskere. Selve udstillingen bestod af genstande og fotos, som vi havde lånt, af Danmarks Frihedsmuseum og af mange private. Udstillingen fortalte også om de store karantænestationer, der var i Padborg og Kruså. I tilknytning til udstillingen var der udarbejdet en lysbilledseries med indtalte kommentarer på bånd. Den blev meget benyttet af de mange besøgende.

Målet for årets aftenudflugt var dels Nydam mose, hvor man hørte om både de gamle og de nyeste fund, og dels var man på rundtur i Varnæs sogn ved Varnæs Skovsø, kirken og kirkegården under kyndig ledelse af $\mathrm{Ib}$ Andersen, Varnæs.

Den 24. oktober holdt lektor $\mathrm{H}$. Becker-Christensen foredrag i Frøslev om "Sønderjyllands deling 1918-20«.

Den sidste lørdag før jul deltog Bov museum i forretningernes julearrangement. Julemanden blev hentet på museets loft. 300 voksne og børn deltog i arrangementet.

Den 18. marts holdt fhv. gårdejer G. Nielsen, Hokkerup foredrag på Holbøl Landbohjem med emnet »Udskiftningen i Hokkerup i 1788«. Padborg sangkor medvirkede. 
Generalforsamlingen holdtes den 16. april. Foreningen har nu 320 medlemmer. Efter generalforsamlingen underholdt "De 5 frøslever «, efterkommere af hjemstavnsdigteren og kromanden fra Frøslev, Karsten Thomsen, med sang og oplæsning af hans digte på Frøslev mål.

Foreningens årsskrift for 1985 rummede bl.a. artikler om de forskellige sangforeninger i gamle dage og artikler i forbindelse med besættelsestiden.

H. H. Bang

\section{Historisk forening for Gråsten by og egn}

Foreningens sommerudflugt gik til Brundlund slot, hvor stiftamtmand Perch Nielsen venligt havde åbnet dørene for et aftenbesøg. Stiftamtmanden fortalte om slottets historie og om den omfattende restaurering, der netop var afsluttet, og om de oplysninger om slottets bygningshistorie, restaureringen havde afsløret. Derefter beså vi udstillingen i porthusets tidligere fængselsceller.

Fra slottet gik turen videre til Folkehjem, hvor Poul Andersen fortalte om de portrætter, der pryder væggene i billedsalen, billeder af kvinder og mænd, der på forskellig vis har ydet en indsats i landsdelen.

Ved efterårsmødet fortalte skoleinspektør Riis-Vestergård om Ejderens forløb. Med en række smukke lysbilleder fulgte vi Ejderen, fra den som en beskeden kilde har sit udspring sydvest for Kiel, til den som en flod løber ud i vest. Også den 200 år gamle Ejderkanal med resterne af de sluser, der endnu findes, så vi billeder af og fik fortalt kanalens bygningshistorie.

På mødet kunne vi udlevere vort årsskrift for 1985. Det bringer artikler af seminarielektor Verner Bruhn, der beretter om, hvordan han oplevede krigsårene 1940-45 som dreng i Gråsten. Arkitekt H. Munk Hansen fortæller om teglværker i Rinkenæs sogn. Den tredie artikel er skrevet af kriminalassistent J. V. Hansen, der fører læseren på en byvandring gennem Gråsten i slutningen af trediverne. Desuden rummer årsskriftet glimt fra årets gang.

Sammen med det lokalhistoriske arkiv stod foreningen for en udstilling på biblioteket $i$ anledning af 40-året for Danmarks befrielse. Udstillingen gav et godt billede af besættelsestiden både på landsplan, og som krigsårene blev oplevet på Gråstenegnen.

Ved generalforsamlingen den 16. april 1986 talte redaktør J. Wolff om emnet: Kan vi fastholde vor frihed? Med alvor, men også med lune, beskrev han den passive og materialistiske holdning, der idag er så fremtrædende i det danske folk.

Poul Andersen

\section{Lokalhistorisk Arkiv for Dybbøl, Ulkebøl og Sønderborg}

Ved foreningens generalforsamling den 18 . februar 1986 blev det oplyst, at foreningens medlemstal er nået op på 270 .

I det forgangne år har der været holdt flere medlemsarrangementer, nemlig forevisning af en ny film om "e ringri'en «, en udstilling om besættelsestiden, et besøg i Ulkebøl kirke, en slentretur langs havnen på Sundeved-siden af 
byen og en tur gennem det gamle Sønderborg med foreningens fremtidige domicil »Den gamle Præstegård« som mål.

Restaureringsarbejdet på den over 300 år gamle bygning på Kirkegade går fortsat fremad, og der er gjort adskillige yderst interessante fund ved udgravningerne. Selve indflytningen forventes at finde sted sidst på året.

Også foreningens Ulkebøl-arkiv er flyttet, idet de hidtidige lokaler er blevet inddraget til kollegiebyggeri. I stedet er arkivet flyttet til en tidligere forretning i Ulkebøl-Centret.

Regnskabet viser en ret pæn konsolidering, hvilket bestyrelsen har ment nødvendig på grund af de noget usikre økonomiske udsigter omkring flytningen af de to arkiver; af samme årsag er udgivelsen af lokalhistoriske publikationer blevet stillet lidt $i$ bero.

Efter generalforsamlingen holdt Henrik Fangel et spændende foredrag om nordslesvigske miljøproblemer før 1920.

Verner Meier

\section{Slægtshistorisk Forening Sønderjylland, 1985}

Foreningen har i det gangne foreningsår bevæget sig fra sørøvere til sølvkøbere!

Efterårshalvåret startede med et spændende foredrag om Kaperskippere fra Sønderjylland, et emne som cand. jur. Finn Grove-Rasmussen behersker suverænt. Det drejede sig om tiden under Englands-krigen 1807-1814 og det legaliserede sørøveri, som kaperskipperne bedrev. En rundtur i de dødes sogn under sagkyndig ledelse af overbetjent K. E. Jensen fra Padborg demonstrerede med al tydelighed, at man $i$ de pågældende sogne havde begravet sine døde på kirkegården i et mønster, der svarede til deres bopæl i live, østensogns folk på østsiden, vestensogns folk på vestsiden, så at gravene dannede et kort over sognet.

Foreningens medlem Valdemar Dreyer trak fuldt hus i november med en meget fornøjelig og spændende fremstilling af, hvorledes han er blevet "Forfulgt af Heldet« i sit arbejde med slægtens historie, og han bragte spændende forbindelser mellem Als og det nordligste Norge for dagen.

Ved et samarbejds- og kontaktmøde på Ahlmann-skolen i Sønderborg fortalte Bodil Clausen, Hans Ole Mørk og Jørgen Wangel om træk af arbejdet med slægtshistorien. Det af Dreyer omtalte held viste sig også her: En gæst medbragte århundredgamle oplysninger om en millionarv fra Ceylon, og et af medlemmerne havde et brev med fra 1911, der handlede om samme arvesag!

Ved generalforsamlingen i marts var der nyvalg til bestyrelsen, da Tove Jensen efter en årrække flittigt arbejde på sekretærposten ønskede afsløsning. Til nyt medlem af bestyrelsen valgtes den hidtidige suppleant, Jens Jørgen Krogsgaard, og til ny suppleant Hans-Ole Mørk, Åbenrå. Efter generalforsamlingen blev forsamlingen bragt til galgen af værten: slotsherren Jørgen Slettebo berettede om nogle skarpretterslægters historie, der viste sig at være særdeles spændende.

I april besøgte foreningen det lokalhistoriske arkiv på Dansk Centralbibliotek i Flensborg, hvor arkivar Lars N. Henningsen fortalte om slægtshistorisk 
litteratur og kilder syd for grænsen. Det var fascinerende at konfronteres med slægtshistoriske arbejder fra 1700-tallet i originaludgave.

Forårsmødet i maj var i Tønder, hvor museumsinspektør Sig. Schouby fortalte om Arvesølvets Tale og efterlyste en udnyttelse af det materiale, der ligger i museets store samling af sølv med samtidige mestermærker og ejerinitialer, der kan medvirke til belysning af slægtsforhold. Derpå viste formanden for lokalhistorisk forening det lokalhistoriske arkiv frem, og medlemmerne fik chancen for at benytte materialet på stedet.

Foreningens medlemstal har nu passeret de 100.

Jorgen Wangel

\section{Historisk Samfund for Sønderjylland}

\section{Amtskredsenes arbejde}

\section{Haderslev amtskreds}

Efter de sidste års aktivitet $\mathrm{i}$ Østeramtet, havde amtskredsen inviteret til egnsvandring i Vesteramtet, under ledelse af Holger Holst og Søren Rasmussen, $\mathrm{i}$ den naturskønne og historisk interessante egn ved Enderupskov og Stensbæk. Mødestedet var Skt. Thøgers rasteplads.

Vi hørte først om den forsvundne Skt. Thøgers kirke og om sagnene, der knytter sig til den, om præsten Hans Fynbo, der ikke ville afsværge sin katolske tro, og om kirkens undergang sidst i 1500-tallet. Så kørte vil til Stensbæk, hvor vi foretog en vandring $i$ det særprægede landskab og endte oppe på Ballumbjerg, hvor vi nød udsigten, og fik en forklaring på, hvordan landskabet er opstået. Herfra kørte vi til "Aftægten« og hørte her sagnet om, hvordan de gamle bønder fik et pund tobak og en flaske brændevin, og så blev de sat på en halvvogn og skubbet ned af skrænten og ned i Gelsåen. Vi hørte også om plantagen i Stensbæk, der blev plantet af den tyske stat, der omkring århundredeskiftet havde opkøbt tre gårde på tilsammen henimod 1000 ha. Afslutningen fandt sted på Enderupskov vandrehjem, hvor borgmester Anton Paulsen, Gram, fortalte om den gamle Enderupskov skole, der er blevet til lejrskole, campingplads og vandrehjem. Vi var begunstiget af meget smukt vejr, og der var stor tilslutning.

Den 25. januar var samtlige lokalhistoriske arkiver og foreninger indbudt til orienteringsmøde i Hygum; først besøgtes det lokalhistoriske arkiv og det nyindrettede museum. I forsamlingshuset fortalte konsulent for lokalhistorie Henrik Fangel om sit arbejde i de lokalhistoriske foreninger, mens repræsentanter for samtlige 16 mødte foreninger gav en kort beskrivelse af de respektive foreningers arbejde.

Poul Andersen berørte i sit indlæg, at det var Historisk Samfunds opgave at støtte og fremme al lokalhistorisk arbejde, men han så gerne arbejdet samlet i større enheder, en udtalelse, der gav anledning til nogen debat, men der var enighed om, at et samarbejde sognene imellem gav større styrke udadtil.

30. april var der generalforsamling i Haderslev museums foredragssal.

På valg var Karl Erik Olesen, Starup, og Søren Rasmussen, Hygumskov: begge blev genvalgt. 
Efter generalforsamlingen var der foredrag af forstander A. B. Keck, Haderslev, der omtalte de tre gamle landsdelslove. Derefter fortalte han om Gram herreds tingsted i Tørning og begivenheder, der havde fundet sted ved tingstedet og nævnte tilsidst tavlestriden mellem Hans Nissen fra Hammelev og den tyske herredsfoged Kjer.

S. $R$.

\section{Abenrå amtskreds}

Åbenrå amtskreds havde den 17. juni arrangeret aftenbesøg på Løjt land. Besøget foregik i samarbejde med Løjt sogns lokalhistoriske forening.

Først var man med bus rundt på Løjt land. Museumsinspektør Steen Andersen, Haderslev, fortalte om de oldtidsmindesmærker, man passerede, og man beså nogle af dem. Efter kaffebord i Løjt forsamlingshus foreviste sognepræst Jens Bruhn Løjt kirke. Der var 70 deltagere.

I anledning af Åbenrå byjubilæum var der to foredrag om byen. Den 23. september holdt middelalderarkæolog Lennart Madsen lysbilledforedrag om købstadens middelalder og om de udgravninger, som han havde foretaget $i$ byen. Den 25. november holdt lektor $\mathrm{H}$. Becker-Christensen foredrag om Åbenrå bys historie 1945-70. Begge arrangementer foregik på Landsarkivet og havde god tilslutning.

To arrangementer er blevet holdt sammen med lokalhistoriske foreninger. Den 3. december i Varnæs om emnet "Lillebanen-Gråsten-Åbenrå« og den 25. februar i Bovrup med emnet "Nødpenge«.

Den 13. november havde amtskredsen inviteret repræsentanter fra de forskellige lokalhistoriske foreninger til et møde i Kliplev. Der var god tilslutning fra disse foreninger. Den nye lokalhistoriske konsulent $\mathrm{H}$. Fangel havde man inviteret til at redegøre for sit arbejde. Kliplev sogns lokalhistoriske forening viste os sine lokaler og fortalte om sit arbejde. Man sluttede på Mørks kro, hvor de forskellige foreninger redegjorde for deres virke, og man udvekslede erfaringer. Amtskredsen finder dette uformelle samarbejde med de lokalhistoriske foreninger meget værdifuldt.

Den årlige generalforsamling afholdtes den 13. april i Billedsalen på Folkehjem. Til bestyrelsen nyvalgtes Inger Jørgensen, Hokkerup, Jens Bruhn, Løjt og Peter Petersen, Kliplev. Fhv. sognepræst Urban Schrøder trak sig tilbage efter 23 års trofast medlemskab af bestyrelsen. Formanden udtalte mindeord over afdøde bestyrelsesmedlem Knud Jensen, Padborg.

Efter generalforsamlingen holdt stud. mag. H. Schultz Hansen, Århus foredrag om emnet »Rig og fattig i Løjt sogn«.

H. H. B.

\section{Sonderborg amtskreds}

Generalforsamling blev holdt 21.5.1985 i Forsamlingsgården i Vester Sottrup. Til bestyrelsen nyvalgtes Bent Oluf Bille, Broager, og Knud Rasmussen, Egen. Forud for generalforsamlingen var vi i Sottrup Kirke, hvor pastor Lorenz P. Christensen fortalte om kirkegården og kirken, og senere på aftenen redegjorde pastoren for frimenighedens og sognemenighedens historie og for danske og tyske kirketraditioner i sognet.

Det årlige møde med de lokalhistoriske foreninger $\mathrm{i}$ amtskredsen $\mathrm{d}$. 
30.10.1985 var denne gang arrangeret i samarbejde med Lokalhistorisk Arkiv i Augustenborg. Formanden Hans Lind, Augustenborg, gjorde rede for arkivets historie, vilkår og arbejde, og Bodil Christensen, Asserballe, viste en enestående samling billeder med lokale motiver, malet af en tysk kunstner, der under 1. verdenskrig var vagtmand på Als og fornylig overdraget arkivet. Til slut havde de 53 deltagere lejlighed til at høre den lokalhistoriske konsulent Henrik Fangel, Åbenrå.

Endelig holdt vi 5.2.1986 et møde på Sønderborg Slot, hvor M. Scott Hansen, Ulkebøl, fortalte om Sicherungsstellung Nord, illustreret med lysbilleder. Det var et glimrende foredrag om stillingens historie og indretning og om Scott Hansens forskningsmetoder, men med alt for få tilhørere.

H. L.S.

\section{Tonder amtskreds}

Vor egnsvandring gik i år til Skærbækegenen. Lørdag d. 29. juni mødtes vi på det nye museum i Skærbæk, der var blevet indviet d. 16. juni. H. E. Sørensen tog imod os, og Peter Petersen var kommet fra Rømø og fortalte om de fine Rømøstuer med fliser og gode ting i porcelæn, sølv og meget mere. Interessant var det også at se, hvor meget der var samlet af redskaber og gamle ting fra egnen. Der var også en maleriudstilling. Bagefter var der kaffebord i den gamle Melby kro, hvor Svend Oksen fortalte om museet. Efter kaffen kørte vi i det fine vejr til pastor Jacobsens karpedamme i Gaansager, - vi havde en fin eftermiddag. Desværre var der alt for ringe tilslutning fra medlemmerne. Den 10. februar var vi medindbyder til afstemningsfest $i$ Skærbæk. Den årlige generalforsamling holdtes d. 11. marts 1986 på „Tønderhus«. Til ordstyrer valgtes Aksel Pedersen. Formanden aflagde beretning om aktiviteter $\mathrm{i}$ det forløbne år og planer for det nye år. Kasserer Carl Nielsen forelagde det reviderede regnskab. Beretning og regnskab godkendtes. På valg var Erik Posselt, Møgeltønder og Carl Nielsen, Højer. Begge blev genvalgt. Efter generalforsamlingen talte lokalhistorisk konsulent Henrik Fangel over emnet: "Træk af dagliglivet i Nordslesvig under 1. verdenskrig«.

E. $P$.

\section{Sydslesvigs amtskreds}

Amtskredsens program blev planlagt på et styrelsesmøde den 18. april 1985.

Den årlige generalforsamling gennemfortes den 9. maj med overbibliotekar Jørgen Hamre som mødeleder. Formandens og kassererens beretninger blev godkendt. Anna Schrøder og Flemming Møller genvalgtes som styrelsesmedlemmer, bibliotekar Carsten Reyhér, Drage ved Frederiksstad, valgtes ind $\mathrm{i}$ styrelsen.

Styrelsens programforslag for 1985 blev drøftet og vedtaget.

Efter kaffebordet talte Franz Wingender om det meget spændende emne "Illegale blade i Sydslesvig efter 1945«. De 34 deltagere hørte om et for dem ukendt kapitel af de dansksindede sydslesvigeres kamp mod englændernes danskuvenlige besættelsespolitik. Ved hjælp af illegale blade og løbesedler, flaghejsning på høje skorstene og natlige plakatkampagner skaffede sydslesvigerne sig gehør i striden for et "frit Sydslesvig«. - Foredraget vil i udvidet form blive udgivet af studieafdelingen. 
Aftenvandringen fandt sted den 13, juni. Hr. Naurocki viste 29 deltagere rundt i Slesvig bys nye rådhus. Vi så det restaurerede Gråkloster og resterne af den gamle Kongsgård og beundrede "Stændersalen«, hvor P. Hiort Lorenzen i 1842 »vedblev at tale dansk «. Efter rundgangen mødtes vi i »Plessengården «s store sal. Her fortalte ældre slesvigere om deres barndom og om det danske arbejde i Slesvig.

Sommerudflugten den 24. august gik til Kær herred. Pastor Paul Tappe var vor sagkyndige guide på turen fra Ladelund Kirke over Dörpskroen i Enge til Enge kirke med dens herlige loftsmalerier. De 32 deltagere hørte om det gamle Kær herred og oplevede det nye Nordfrisland i både solskin og regnvejr.

Ved efterårsmødet den 7. november i Slesvig stiftede man bekendtskab med vikingeeksperten, arkæologen Hans Jørgen Madsen fra Moesgaard. Han illustrerede ved hjælp af lysbilleder en lang række arkæologiske undersøgelser fra vikingetidens Danmark. Hans veloplagte og stofmættede skildring af den tids landsbyer, forsvarsværker, kanal-, bro- og skibsbyggeri inspirerede de $\mathbf{4 8}$ tilhørere til mange spørgsmål, der berørte Hedeby-Trene-kanalen, udgravningerne i Koslev og de nye tyske teorier om Danevirkes alder. Det var en meget vellykket aften - og en glimrende afslutning på årets program.

J. $R$. 


\section{Årsberetning 1985-86}

\section{Ved Poul Andersen}

Den 11. maj 1986 holdt Historisk Samfund for Sønderjylland sit årsmøde på Gram Slotskro, hvor ca. 150 medlemmer var kommet til stede. Efter at formanden havde budt velkommen og havde udtalt sin glæde over det store fremmøde, rettede han en særlig velkomst til foreningens to æresmedlemmer, Troels Fink og Peter Kr. Iversen samt til H. P. Jensen, Agerskov, der efter generalforsamlingen ville fortælle om storbonden Laust Arnum.

Traditionen tro sang man derefter Martin N. Hansens sang: Der er sol over vang.

Formanden udtalte derefter mindeord over den første formand for Aabenraa amtskreds, skoleinspektør Peter Clausen, Hostrupskov, tidligere socialinspektør Olav Christensen, Haderslev, der $i$ en årrække havde været kasserer i Historisk Samfund, og foreningens æresmedlem, viceskoleinspektør Christian Stenz, der i en menneskealder havde været redaktør af Sønderjysk Månedsskrift og styrelsesmedlem.

Generalforsamlingen tog sin begyndelse med valg af skatterådsformand Svend Lyck til dirigent, og han gav straks ordet til formanden, der aflagde følgende beretning:

En af Historisk Samfunds opgaver - nedfældet $i$ vore vedtægter - er at "udgive skrifter vedrørende Sønderjyllands historie«. Denne forpligtelse, mener jeg da også vi lever op til. Siden sidste årsmøde har vi udsendt to bøger. Jeg havde håbet at kunne sige fire, men de to sidste er endnu hos bogbinderen, men kommer inden udgangen af denne måned.

Skriftrækken er oppe på nr. 62, og i den nye serie "Studier" foreligger nr. $2 \mathrm{om}$ et par uger. Foruden disse bøger er $\mathrm{i}$ årenes løb udkommet 23 bind $\mathrm{i}$ serien »Sønderjyske Levnedsløb«, Historisk Billedbog i tre bd., og fem andre bøger uden for de omtalte serier. Ialt 95 større og mindre bøger. Det må betegnes som en betydelig udgivervirksomhed, og det er sket $i$ et tempo, der har krævet en overordentlig stor arbejdsindsats af redaktionerne. Uden at forklejne nogen vil jeg takke Lars Henningsen, der i de seneste år som hovedredaktør af bøgerne har trukket det største læs.

Som sagt har vi udsendt to bøger siden sidste årsmøde. I august måned kom Hans Schultz Hansens bog: Det nordslesvigske landbrug og den danske bevægelse 1880-1914. Bogen blev præsenteret ved en lille sammenkomst $i$ Sparekassen Sønderjylland. Sparekassen havde foruden at være vært ved receptionen givet støtte til udgivelsen og var også behjælpelig med at forhandle bogen. Den er blevet modtaget med stor interesse og er næsten udsolgt. Sparekassen Sønderjylland bringer jeg vor bedste tak for den hjælpsomhed, vi har modtaget $i$ forbindelse med udgivelsen af denne bog. 
I november kunne vi så udgive 4. bind af Aabenraa bys historie. Det skete ved en sammenkomst på rådhuset, hvor en indbudt kreds var samlet med bogens to forfattere, Henrik Becker-Christensen og Jørgen Witte. De to har beskrevet tiden fra 1945-70 og givet et levende billede af dette tidsrum. De redegør objektivt og letlæseligt for dette stykke samtidshistorie. Bogen føjer sig smukt ind i rækken af de tre tidligere bind. Aabenraa kommune har til denne udgivelse ydet en betydelig økonomisk støtte, som vi fra Historisk Samfund siger hjertelig tak for. Jeg kan tilføje, at der arbejdes energisk med byhistoriens fortsættelse - to bind om Løjt og Ensted sognes historie. Forhåbentlig er disse bøger inden for synsvidde ved næste årsmøde.

De to bøger, der som nævnt, kommer i løbet af de næste uger er: professor, dr. phil. Otto Norns bog: To Grænseslotte. Frederik I.s Gottorp og Christian IV.s Koldinghus. Det er blevet en smuk bog med mange spændende billeder og tegninger, heraf flere $\mathrm{i}$ farver. Tekst og billeder giver et godt indblik $\mathrm{i}$ de to slottes bevægede historie, både politisk og arkitektonisk. Gottorp slot får her for første gang sin rette plads i den danske arkitekturhistorie, og kong Frederik I præsenteres i nyt lys. Christian IV.s Koldinghus er ikke før behandlet så indgående som i denne bog. Når man har læst denne bog, har man fået megen viden om 1500-årenes kunst- og arkitekturhistorie, og det vil blive en større oplevelse at besøge de to prægtige bygningsværker.

Den anden bog er overlærer Ib Andersens: Ensted sogns gårde og slægter. Der ligger et grundigt og omhyggeligt udført forskningsarbejde bag denne bog. Efterhånden som landsbyerne tæt ved købstæderne bliver forvandlet til industriområder og villakvarterer, er det af stor værdi, at de gamle landsbysamfunds historie bliver fastholdt, så også denne bog kan jeg anbefale på det bedste.

I Årbogen 1985 har redaktionen igen leveret en årbog med en række gode artikler, der har tilknytning til Sønderjyllands historie, spændende over tiden fra middelalder til vore dage. Foruden artikelstoffet bringer årbogen anmeldelser, samt nyt fra museerne, landsarkivet, Institut for sønderjysk lokalhistorie og en del af de lokalhistoriske foreninger. Alt sammen viser det den grøde, der er i det historiske arbejde. Jeg vil gerne bringe redaktionen en tak for dens store arbejde og det fornemme resultat.

Den store egnsvandring 1985 blev en succes. To dage var vi på farten med 150 deltagere hver dag, og vi måtte desværre afvise nogle, men mere end 150 kan vi ikke være, hvis vi skal holde samling på »tropperne«. Første mål var Moesgård, hvor vi så udstillingen: "Drømmen om Amerika«, der skildrede den store udvandring til den nye verden. Amerika blev også målet for mange sønderjyder, der ville undgå den preussiske trøje og ikke ville leve under tysk styre. Så gik det videre til Illerupdalen, hvor vi fik fortalt om de omfattende udgravninger, der har fundet sted i mange år. Det var fascinerende at besøge dette sted og høre magister J. Ilkjær fortælle om de tusindvis af fund - nogle fik vi forevist, der endnu dryppede af mosevand. Alle belyser de tiden for 1.000 år tilbage. Sidste station var Ejer Bavnehøj. Her holdt universitetslektor Strange Petersen foredrag om den sønderjyske udvandring, der endnu ikke er klart belyst. Det er et område, der nok kan trænge til en nøjere undersøgelse. Selv om det var en udflugt på godt 10 timer, er det mit indtryk, at deltagerne var glade for den. 
Vore amtskredse var tidligere næsten ene om at arrangere foredrag samt by eller egnsvandringer på lokalt plan. I dag må vi nok erkende, at de mange glædeligt mange - nye lokalhistoriske foreninger i nogen grad har taget føringen på dette område, men der findes dog stadig aktivitet $\mathrm{i}$ amtskredsene. Indberetninger viser, at der har været afholdt 16 arrangementer med en tilslutning på ca. 900 af vore medlemmer. Da det for en stor del er de samme, vi møder i lokale foreninger, mener jeg, at vi nok må overveje et nøjere samarbejde, så vi i fællesskab kan trække på samme hammel. Styrelsen har derfor nedsat et udvalg, som arbejder på denne sag.

Som kort omtalt ifjor forbereder vi at markere Sønderjyske Årbøgers 100 års jubilæum med et nyt årbogsregister, der vil være en værdifuld hjælp, når man vil hente oplysninger i årbøgerne. Skoleinspektør Børge L. Barløse har påtaget sig denne meget store opgave, og han er allerede nået langt. Jeg vil gerne her bringe ham vor tak. Vi er trygge ved, at dette arbejde varetages af netop ham.

En tak skal der også lyde til vore medhjælpere på kontoret, Vera Hansen og Erik Jørgensen og til fru Schaumburg, der ved spidsbelastning rækker os en hjælpende hånd.

Og en særlig tak vil jeg sige for den store støtte Historisk Samfund modtager fra amtet, fonde og private institutioner. Det er en hjælp, som ikke kan overvurderes og muliggør, at Historisk Samfund kan løse de mange og store opgaver, vi påtager os.

Skulle nogen i salen mene, at jeg har glemt Sønderjysk Månedsskrift i min beretning, så er det ingenlunde tilfældet. Det er med velberåd hu, jeg har gemt det til afslutning. Som det fremgår af dagsordenen, skal vi idag tage afsked med fru Svensson, efter at hun siden 1963 har været redaktør af Sønderjysk Månedsskrift, og i de sidste år været alene om arbejdet.

Fru Svensson hører til den gruppe af mennesker, der ikke bryder sig om at blive hyldet eller modtage gaver, og man skal ikke trodse fru Svensson. Men da du nu træder ud af styrelsen, så vover jeg det alligevel. Jeg vil sige dig tak for dit store arbejde. I næesten et kvart århundrede har du samlet stof, redigeret det omhyggeligt og måned efter måned leveret et månedsskrift af både folkelig og historisk kvalitet. Et kildeskrift som enhver, der beskæftiger sig med Sønderjyllands historie, gang på gang på benytte.

Personligt vil jeg gerne sige dig tak for et rart og hyggeligt samarbejde. Jeg vil nok komme til at savne vore telefonsamtaler, der som regel begyndte med et problem om Månedsskriftet, men inden længe kom ind på mange områder med gensidige drillerier. Her erkender jeg, at du er min overmand. Vi har ikke altid været enige, men vi blev det $-\mathrm{i}$ al fald når du fik din vilje. I dag er det imidlertid mig der bestemmer, og derfor medbringer jeg en lille gave. Da vi begge er økonomiske naturer, vil det kunne glæde dig, at det er en genbrugsting. Under oprydning $i$ vort lager fandt Lars Henningsen en kliche fra Sønderjysk Månedsskrift, da det i 1941 fik ny forside med de to løver. Denne kliche vil være velegnet til brevpresse og synet af den minde dig om Slesvig og Sønderjysk Månedsskrift. De to løver kan også symbolisere den styrke og kraft, du har lagt $i$ arbejdet. Og skulle du synes, at to løver er for meget, så kan den ene være Bjørn, for begge har I ydet en stor indsats for Månedsskriftet. $\mathrm{Da}$ gaven er så beskeden, så har vi en tillægsgave. Det er kommet os for øre, 
at du har Sønderjysk Månedsskrift liggende uindbundet. Det vil Historisk Samfund råde bod på og sørge for at det bliver indbundet som en tak for, at du på fremragende vis har vogtet foreningens sjældne klenodie - Sønderjysk Månedsskrift.

Og så er jeg ved at nå til vejs ende med min årsberetning, den sidste jeg aflægger i Historisk Samfund. Det skal ikke skjules, at det var med stor betænkelighed, jeg for 6 år siden sagde ja til at overtage formandsposten. Det var der flere grunde til. Jeg følte, at det ville blive vanskeligt at løfte arven efter de fire, der havde skabt og opbygget Historisk Samfund til dets førende plads blandt Danmarks historiske foreninger. Alle fire, H. P. Hanssen, Lausten Thomsen, Troels Fink og vel ikke mindst Peter Kr. Iversen, der $i$ en menneskealder har brugt sin tid og sine kræfter på Historisk Samfund, har betydet meget for foreningens høje stade.

En anden grund var, at jeg allerede var folkepensionist, og klart kunne se, at jeg kun i en beskeden årrække kunne gøre fyldest. Jeg sagde da også kun ja til to år som en slags overgangpave. Men nu er der gået seks år, seks år hvor jeg har været glad for at kunne gøre lidt gavn. Men man skal også gå, før medlemmerne siger: »Kan han da ikke snart gå?»

Som sagt indså jeg, at jeg ikke ville kunne nå at præge Historisk Samfund. Min opgave måtte være at holde "gryden i kog«. Bevare status i medlemstal og i økonomien. M.h.t. medlemmerne er det gået hæderligt med lidt fremgang, kun i mit sidste år har der trods stor tilgang været en lidt større afgang, hvilket jeg dog ikke er så indbilsk at tro skal opfattes som en sympatierklæring, men er udtryk for, at vi er i en sparetid. Kassebeholdningen kan jeg godt være bekendt. Som det fremgår af regnskabet er der midler til at fuldføre de planer om udgivelser, som styrelsen har for den nærmeste fremtid.

Er min formandstid således gået hen uden at sætte dybe spor i Historisk Samfund, så har det for mig, der kan se tilbage på 50 års medlemsskab, været en personlig tilfredsstillelse at blive betroet formandsposten i den forening, jeg har været så nær knyttet til. Jeg føler idag, at jeg har meget at sige tak for. Til de mange medlemmer jeg har truffet og lært at kende ved møderne ude omkring $i$ landsdelen. Til vor store medlemsskare, der stadig slutter op om Historisk Samfund. Til styrelsen for et altid rart samarbejde, og først og sidst for den tillid man viste mig, da man valgte mig til formand. Tak for disse seks år, som har beredt mig så megen glæde. Tak.

Efter formandens beretning tog næstformanden, Knud Fanø ordet og takkede i en stærkt personlig tale formanden, der nu trak sig tilbage, for de år han energisk havde arbejdet for Historisk Samfund. Knud Fanø sluttede sin tale med at overrække formanden en smuk boggave.

Herefter aflagde kassereren, Rasmus Callesen det reviderede regnskab. Efter enkelte spørgsmål til beretning og regnskab godkendtes begge enstemmigt.

På valg var Knud Fanø og N. Kragh Nielsen, der begge blev genvalgt. Da både Poul Andersen og Inger Bjørn Svensson ønskede at 
fratræde, valgtes til nye medlemmer i styrelsen Inge Adriansen og Henrik Fangel. Formanden bød de nyvalgte velkommen til arbejdet og meddelte tillige, at styrelsen havde valgt Hans $H$. Worsøe til formand.

Fru Svensson bad nu om ordet og $\mathrm{i}$ en fornøjelig tale takkede hun for årene i Historisk Samfund. Hun sluttede sin tale med at overrække de tre formænd, hun havde »tjent« under, hver en kuglepen.

Efter kaffebordet fik H. P. Jensen ordet. Stærkt engageret i sit emne, gav han et levende billede af storbonden Laust Arnum. En foregangsmand inden for landbruget og i sit forhold til sine medhjælpere, som kom til at præge sin hjemegn, men som til sidst led nederlag. Et stærkt bifald hilste H. P. Jensens foredrag. Efter forskellige spørgsmål fra salen takkede dirigenten for foredraget, hvorpå formanden afsluttede mødet med at takke for de mange venlige ord, der havde lydt til ham. Og det vellykkede årsmøde sluttede med, at man sang: Hvor smiler fagert den danske kyst. Efter mødet var der mulighed for et besøg på Gram museum, hvilket mange af deltagerne benyttede sig af. 
Driftsregnskab for året 1. januar til 31. december 1985

Udgifter:

Sønderjyske Årbøger

$191.884,87$

Sdj. Månedsskrift

Trykning $\ldots \ldots \ldots \ldots \ldots \ldots \ldots \ldots \ldots$ 178.856,02

Porto . . . . . . . . . . . . . . . . 34.126,86

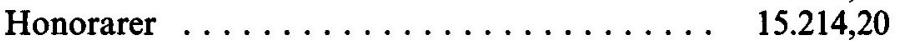

Lydbånd $\ldots \ldots \ldots \ldots \ldots \ldots \ldots \ldots \ldots \ldots$ 1.894,70

Skrifter

$\begin{array}{r} \\ \\ \\ 230.091,78 \\ \hline 291.837,18 \\ 35.054,55 \\ 7.322,22 \\ 23.365,17 \\ 3.000,00 \\ 8.065,98 \\ 6.486,00 \\ 4.391,87 \\ 5.912,50 \\ 9.174,74 \\ 68.579,25 \\ 4.099,70 \\ 7.822,03 \\ \hline 897.085,84 \\ 608.872,94 \\ \hline 1.505 .958,78 \\ \hline \hline\end{array}$

Porto .

Amtskredse

Egnsvandring $5.214,20$
$1.894,70$

Kontingent

Broch. introduktionsskrivelse

Slægtshist. kursus

Telefon

Årsmøde

Kontorudgifter

Lonninger

Møder

Repræsentation, honorarer

Beholdning pr. 31.12.1985

Status pr. 31.12.1985

Aktiver:

Beholdning $\ldots \ldots \ldots \ldots \ldots \ldots \ldots \ldots \ldots$

Tilgodehavende for salg

$608.872,94$

Tilgodehavende for moms

$26.405,00$

Tilgodehavende lønref.

$52.462,71$

$19.040,04$ 
Indtagter:

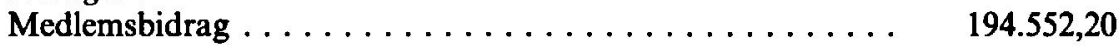

Sdj. Månedsskrift

Abonnement . . . . . . . . . . . . 152.277,37

Annoncer $\ldots \ldots \ldots \ldots \ldots \ldots \ldots \ldots \ldots$ 9.933,05

Ældre månedsskrift $\ldots \ldots \ldots \ldots \ldots \ldots \ldots . \quad 3.996,50$

Tilskud $\ldots \ldots \ldots \ldots \ldots \ldots \ldots \ldots \ldots \quad 35.000,00$

Lydbånd $\ldots \ldots \ldots \ldots \ldots \ldots \ldots \ldots \ldots \quad \mathbf{4 . 4 0 0 , 0 0}$

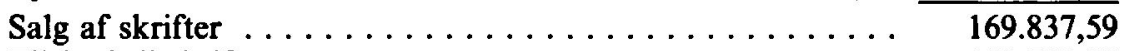

Tilskud til skrifter . . . . . . . . . . . . . . . 188.700 .00

Tilskud iøvrigt $\ldots \ldots \ldots \ldots \ldots \ldots \ldots \ldots \ldots \ldots \ldots . \mathbf{8 5 . 8 8 7 , 5 0}$

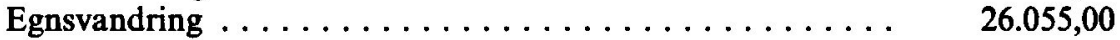

Slægtshist. kursus $\ldots \ldots \ldots \ldots \ldots \ldots \ldots \ldots \ldots \ldots \ldots$

Renter ........... 65.066,22

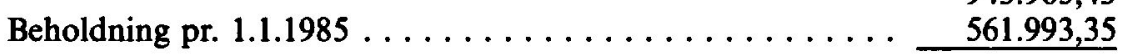

$1.505 .958,78$

Passiver

Egnsvandringsfond $\ldots \ldots \ldots \ldots \ldots \ldots \ldots \ldots \ldots \ldots \quad 12.990,00$

Henlagt til:

Biografier . . . . . . . . . . . . . . . . . . . $\quad \mathbf{2 9 . 0 0 0 , 0 0}$

Årbogsregister . . . . . . . . . . . . . . . . . . $150.000,00$

Aabenraa Bys Historie . . . . . . . . . . . . . . 192.360,00

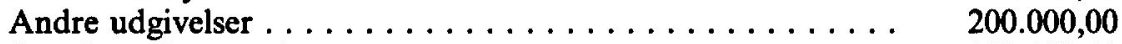

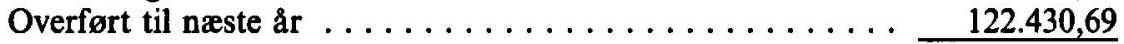

$706.780,69$

Aabenraa, den 15.2.1986

Rasmus Callesen

Foranstående regnskab har vi revideret og fundet $\mathrm{i}$ overensstemmelse med bilag, giro-, bank- og sparekassekonti.

Aabenraa, den 25.2.1986

sign. S. Lyck sign. C. O. Henningsen 


\section{Tillæg til medlemsfortegnelsen}

Efterfølgende supplement til den i årene 1955 til 1985 offentliggjorte medlemsfortegnelse for Historisk Samfund for Sønderjylland medtager som i de foregående år i afgangslisten kun de afdøde medlemmer, hvis død er kommet til vort kendskab, medens tilgangslisten omfatter alle de nye medlemmer $i$ alfabetisk rækkefølge, tilmeldt i tiden 1. januar-31. december 1985 .

Pr. 31. december 1985 udgjorde medlemstallet 2943, der fordelte sig på Sønderjylland og det øvrige land samt udlandet som følger:

Haderslev by og amt ...... 640

Sønderborg by og amt ..... 306

Tønder by og amt ....... 365

Aabenraa by og amt . . . . . 694

Sydslesvig . . . . . . . . 175

Udlandet ............ 20

Øvrige Danmark . . . . . . . . 743

Afgået ved doden

Birck, Maria, Åbenrå

Bjer, Ole, direktør, Sønderborg

Ertbøl, stationsforstander, Århus

Holm, Jacob, dyrlæge, Skodborg

Jacobsen, H. J., fhv. regionschef,

\section{Rønne}

Jacobsen, Helga, E. C., København F

Jensen, Helge Børnsen, larer, Ladelund

Jespersen, Sigfred, programredaktør, Åbenrå

Jørgensen, Else Marie Skov, Vanløse

Kurtzweil, P., revisor, Bagsværd

Laursen, Poul Møller, major, Tønder

Michelsen, R., dyrlæge, Åbenrå

Nielsen, Asta, Rinkenæs

Petersen, Em., overassistent, Tønder

Petersen, Margrethe, Tønder

Rasmussen, Aage, viceskoleinspektør,

Broager

Roesen, Børge, domprovst, Ravsted

Scharff, A., professor, Kiel

Egidius, Karl Emil, landinspektør, København $\mathrm{F}$

\section{Nye medlemmer}

Agertoft, Svend, kirkesanger, Åbenrå

Andersen, Karl-Erik, Århus C

Auring, Grete, Åbenrå

Barsøe, Sonja, Egernsund
Bartrup, Erik, Vojens

Beck, Ingrid, Agerskov

Beck, Kirsten, højskolelærer, Rønshoved

Beltoft, Annagrethe, Bov

Bennetsen, Knud, Rødding

Bertelsen, Flemming, Løjt Vestervang

Beyer, Vagn, Odense

Biblioteket, Esbjerg

Biblioteket, Haderslev

Biblioteket, Roskilde Universitet

Boisen, Peter, arkitekt, Rødekro

Borg, Marie, Gram

Buchard, Birgit, Kastrup

Bærenholdt, Bent Ole, Odsherreds Efterskole

Callesen, Povl, sognepræst, Varnas

Carl, Merete og Jørn, Kolding

Christensen, Carl, Haderslev

Christensen, Henry, Åbenrå

Christensen, Niels Rodkær, overlærer, Tønning

Damkjer, Ingeborg og Olaf, Kolding

Det sønderjyske Landsbibliotek

Emborg, Elisabeth, Gråsten

Erbs, Hans Peter, sognepræst, Øster Logum

Eliasen, E., Nivå

Eliasen, Flemming, Nivå

Essemann, J. C., oberst, Haderslev

Flensborg Avis, Åbenrå

Franzen, F. C., lektor, Haderslev

Gammelgård, Harald, Rødding

Gregersen, Gregers, Tinglev

Hansen, Hans, Skærbæk

Hansen, Svend Aage, Sakskøbing

Hansen, T. Vest, læge, Tønder

Hansen, Vera, Kongsmark 
Hansen, Vera Molberg, Åbenrå

Harsholt, Geske, Thurø

Hattesen, Gunnar, Århus

Hell, Mathias, Åbenrå

Hinrichsen, Rolf, Lysabild

Hollesen, K., Odense

Holm, Tove, Årøsund

Iversen, Peter, tryktekniker, Arhus

Jensen, Anker A., overlærer, Løjt Kirkeby

Jensen, A. K., Hejls

Jensen, Egon Wrang, bankfuldmægtig, Åbenrå

Jensen, Ib Ansgar, Esbjerg

Jensen, Ingvar, Skovby

Jensen, Jacob B., Haderslev

Jensen, Petra, Åbenrå

Jensen, Rudi, kundechef, Tønder

Jespersen, Kurt, Vojens

Jespersen, Peter, Varde

Jessen, Elisabeth Holstein, Århus

Jessen, Erik, gårdejer, Rødding

Jessen, Jing, Vojens

Johansen, Birgit, højskolelærer, Sønderhav

Jørgensen, E. Fogh, snedkermester, Rinkenæs

Kliver, Bente, Hammelev

Knudsen, Heine, afdelingsleder, Rødekro

Korsgaard, Sofie, Åbenrå

Kristensen, Erik, assistent, Rødovre

Kromann, Johan, København K

Kryger, F., Ábenrå

Kaad, Hans Aage, Sorø

Larsen, Birgit, Skodborg

Larsen, Lise Rosendal, Genner Strand

Larsen, Mette, Bredebro

Lauszus, Andreas, overlærer, Flensborg

Lemming, Bodil, Esbjerg

Lindsø, Erik, museumspædagog, Haderslev

Lorenzen, Grethe, Gesten

Lorenzen, Hans, Blans

Lund, Annelise, Ellund

Lund-Mikkelsen, A., Bovrup

Madsen, Claus, Århus

Madsen, Dorthe, Skanderborg
Madsen, Karen og Nicolai, Genner Strand

Mandau, Gudrun, Sdr. Vilstrup

Markussen, Frederik, Frifelt

Metz-Andersen, Jørgen, Tjørring

Michaelsen, Michael, gårdejer, Sommersted

Michelsen, Carl E., dyrlæge, Tønder

Mortensen, A., konsulent, Gram

Mosegaard, Marie, Sommersted

Møller-Jensen, Niels, bankfuldmægtig, Rødekro

Nielsen, Anders, Haderslev

Nielsen, Ebbe Fink, Rinkenæs

Nielsen, J. Bach, præst, Broager

Nielsen, Severin, København $\emptyset$

Nissen, Lilian, Kolding

Nissen, Rigmor, Stenderup

Norn, J., Ullerup

Norstved, Dorte, »Høgebjerg«, Åbenrå

Olsen, Aug., boghandel, Hellerup

Pedersen, Anna Marie Dall, overlærer, Høruphav

Petersen, Carsten Thade, Munkebo

Petersen, Else Bollerup, Rødding

Philip, Birthe, borgmester, Charlottenlund

Poulsen, Bjørn, magister, Flensborg

Rasmussen, Jan, Broager

Rasmussen, Ulla, Åbenrå

Raun, Aase, Darum

Reinholdt, Ole, cand.jur., Bolderslev

Rhodos Int. Tidsskrifthandel, København $\mathrm{K}$

Rønholt, J. P., »Juhlsminde«, Hammelev

Schibler, Mogens, Åbenrå

Schmidt, Peder, Kobenhavn K

Schou, Kirsten, overlærer, Sønderup

Seeber, Bernhard, sadelmagermester,

Haderslev

Simonsen, Simon, Gram

Sloth, Cathrine, Ribe

Statsbiblioteket, Århus

Stockman, Henrik, Dansk Bogservice, København S

Styrk, Peter, Vojens

Sørensen, Svend Falkner, Århus C 
Tamm, Ditlev, professor, København $\emptyset$ Therkelsen, Knud Erik, højskolelærer, Rønshoved

Thomsen, Benny, rembourschef, Ábenrå
Thorsen, Georg, Kolding Troelsen, Hans Tage, Bredebro Vagtel, Helge, Århus C

Weber, Sonja, Åbenrå 


\section{Bliv abonnent på Sønderjysk Månedsskrift!}

Vidste De, at Historisk Samfund for Sønderjylland også udgiver et månedsskrift med korte velillustrerede artikler, der giver glimt af Sønderjyllands spændende historie fra oldtiden til i dag?

Las om

- nye arkæologiske og historiske undersøgelser,

- kendte og ukendte seværdigheder,

- nye bøger om Sønderjylland,

- aktuelle begivenheder $\mathrm{i}$ grænselandets kultur- og samfundsliv, og meget andet.

SØNDERJYSK MÅNEDSSKRIFT udkommer 10 gange om året, og hvert nummer er på ca. 36 sider.

Pris kun kr. 95 (incl. forsendelse).

Introduktionstilbud: $25 \%$ rabat for nye abonnenter.

Ønsker De først at lære SØNDERJYSK MÅNEDSSKRIFT lidt nærmere at kende, kan De gratis få sendt 2 prøvenumre.

Abonnement kan tegnes og prøvenumre bestilles hos Historisk Samfund for Sønderjylland, Ekspeditionen, Haderslevvej 45, 6200 Aabenraa, tlf. 04624683 .

\section{Spændende bog om to grænseslotte:}

\section{Otto Norn: TO DANSKE GRÆNSESLOTTE - GOTTORP OG KOLDINGHUS}

Gottorp Slot blev i 1. halvdel af 1500-årene ombygget til et for sin tid enestånde renæssancepalads o. 1600 lod Christian IV Koldinghus renovere, og han prydede slottet med det berømte kæmpetårn. Professor, dr.phil. Otto Norns bog giver for første gang på dansk en dybtgående redegørelse for de to slottes bygningshistorie. Forfatteren tolker ud fra helt nye synsvinkler arkitekturen som udtryk for den protestantiske fyrsteopfattelse efter reformationen. Takket være tilskud kan bogen udsendes i overdådigt udstyr, med farvebilleder og talrige sort/hvide illustrationer ledsaget af spændende billedtekster. Det er en lakkerbisken for alle med interesse for kunst-, arkitektur- og idehistorie. Når De har læst denne bog, vil De betragte de to kendte slotte med nye øjne. $160 \mathrm{~s}$. indb. kun kr. 70 for medlemmer (+ porto).

Bogen kan bestilles på ovenstående adresse. 


\section{Julebogpakke}

Mangler De ideer til julegaver? -

så benyt Dem af Historisk Samfunds julebogpakke: 4 bøger for $125 \mathrm{kr}$. (+ forsendelsesomkostninger)

De fire bøger er

1) Peder Andholm: Sømandsliv og guldfeber, 1981, $195 \mathrm{~s}$. - en unge sømands spændende oplevelser som sømand på de store sejlskibe og som guldgraver i Australien og New Zealand 1854-1864 (normalpris $70 \mathrm{kr}$.).

2) Sønderjylland: Historisk billedbog 1864-1920, 1979, $215 \mathrm{s.}$

- smuk bog, der i billeder fortæller Sønderjyllands spændende historie under fremmedherredømmet. Her berettes om folkelige bevægelser, om nationale modsætninger og periodens store samfundsmæssige ændringer (normalpris $75 \mathrm{kr}$.).

3) Hans J. Hansen: Alsisk landmandsvirke, 1979, $153 \mathrm{s.}$

- erindringer fra Als, hvor forfatteren fortæller om sin barndom, om sin deltagelse i 1. verdenskrig og om sit arbejde som landmand efter 1920 med nationale modsætninger og landbrugskrise (normalpris $25 \mathrm{kr}$.).

4) Hans J. Muusmann: Stavedskov - Ejstrup - Kragelund, 1980, $188 \mathrm{s.}$ - erindringer fra Vestslesvig og Tinglev-egnen med interessant skildring af levevilkår før 1. verdenskrig og af tiden efter $1920 \mathrm{i}$ et sogn nær grænsen (normalpris $45 \mathrm{kr}$.).

Julebogpakken kan bestilles hos

Historisk Samfund for Sønderjylland, Ekspeditionen, Haderslevvej 45, 6200 Aabenraa, tlf. 04624683 .

Husk at mærke bestillingen »Julebogpakke«.

Tilbuddet gælder så længe lager haves.

\section{Studier}

I serien Studier, udgivne af Historisk Samfund for Sønderjylland, er udkommet nr. 2:

Ib Andersen: Gårde og slægter i Ensted sogn, 1986, 230 s. ill.

- tusindvis af enkeltoplysninger er samlet til et billede af bondefamiliernes og sognets liv gennem århundreder. Meget fă sogne har en så værdifuld gård- og slægtshistorie. Bogen er en skatkiste for slægts- og lokalhistorikere.

Pris for medlemmer $75 \mathrm{kr}$. + porto. 

